\title{
The globally distributed genus Alexandrium: Multifaceted roles in marine ecosystems and impacts on human health
}

\author{
Donald M. Anderson ${ }^{\mathrm{a}, *}$, Tilman J. Alpermann ${ }^{\mathrm{b}}$, Allan D. Cembella ${ }^{\mathrm{c}}$, Yves Collos ${ }^{\mathrm{d}}$, \\ Estelle Masseret $^{\mathrm{d}}$, Marina Montresor ${ }^{\mathrm{e}}$ \\ ${ }^{a}$ Woods Hole Oceanographic Institution, MS \# 32, 266 Woods Hole Road, Woods Hole, MA 02543, United States \\ ${ }^{\mathrm{b}}$ LOEWE Biodiversity and Climate Research Centre (BiK-F), Senckenberg Research Institute, Senckenberganlage 25, 60325 Frankfurt a.M., Germany \\ ${ }^{c}$ Alfred Wegener Institute for Polar and Marine Research, Am Handelshafen 12, 27570 Bremerhaven, Germany \\ d Ecologie des Systèmes Marins Côtiers, UMR 5119, UM2, CNRS, IRD, Ifremer, UM1, Université Montpellier 2, CC 093,34095 Montpellier, France \\ e Stazione Zoologica Anton Dohrn, Villa Comunale, 80121 Napoli, Italy
}

\section{A R T I C L E IN F O}

Article history:

Available online 25 October 2011

\section{Keywords:}

Alexandrium

Harmful algal blooms

$\mathrm{HAB}$

Biotoxins

Public health

Global dispersion

\begin{abstract}
A B S T R A C T
The dinoflagellate genus Alexandrium is one of the major harmful algal bloom (HAB) genera with respect to the diversity, magnitude and consequences of blooms. The ability of Alexandrium to colonize multiple habitats and to persist over large regions through time is testimony to the adaptability and resilience of this group of species. Three different families of toxins, as well as an as yet incompletely characterized suite of allelochemicals are produced among Alexandrium species. Nutritional strategies are equally diverse, including the ability to utilize a range of inorganic and organic nutrient sources, and feeding by ingestion of other organisms. Many Alexandrium species have complex life histories that include sexuality and often, but not always, cyst formation, which is characteristic of a meroplanktonic life strategy and offers considerable ecological advantages. Due to the public health and ecosystem impacts of Alexandrium blooms, the genus has been extensively studied, and there exists a broad knowledge base that ranges from taxonomy and phylogeny through genomics and toxin biosynthesis to bloom dynamics and modeling. Here we present a review of the genus Alexandrium, focusing on the major toxic and otherwise harmful species.
\end{abstract}

(c) 2011 Elsevier B.V. All rights reserved.

\section{Introduction}

Among the genera responsible for harmful algal blooms (HABs), the genus Alexandrium is certainly one of the most important in terms of the severity, diversity, and distribution of bloom impacts. Of the more than 30 morphologically defined species in this genus, at least half are known to be toxic or have otherwise harmful effects (Table 1). One unique feature of this genus is that three different families of known toxins are produced among species within it - saxitoxins, spirolides, and goniodomins. This toxigenic diversity is not found in any other HAB genus.

The most significant of these toxins in terms of impacts are the saxitoxins, responsible for outbreaks of paralytic shellfish poisoning (PSP), the most widespread of the HAB-related shellfish poisoning syndromes. The impacts of PSP outbreaks include human intoxications and death from contaminated shellfish or

\footnotetext{
* Corresponding author. Tel.: +1 5082892351.

E-mail addresses: danderson@whoi.edu (D.M. Anderson),

Tilman.Alpermann@senckenberg.de (T.J. Alpermann), Allan.Cembella@awi.de (A.D. Cembella), yves.collos@univ-montp2.fr (Y. Collos),

estelle.masseret@univ-montp2.fr (E. Masseret), marina.montresor@szn.it

(M. Montresor).
}

fish, loss of wild and cultured seafood resources, impairment of tourism and recreational activities, alterations of marine trophic structure, and death of marine mammals, fish, and seabirds. The macrocyclic imine spirolides, thus far known only from Alexandrium ostenfeldii (Cembella et al., 2001) and possibly Alexandrium peruvianum (as listed in the IOC taxonomy database; Moestrup et al., 2011), are potent fast-acting neurotoxins when administered intraperitoneally into laboratory rodents. No human cases of shellfish poisoning from spirolides have been documented, however, and subsequent toxicological investigations have not justified their inclusion in regulatory regimes for seafood toxicity. The goniodomins produced by Alexandrium monilatum and $A$. hiranoi (formerly Goniodoma pseudogonyaulax; Hsia et al., 2005) cause paralysis and mortality in finfish. They are not linked to human illness, and are not a major problem on a global scale.

Many of the species within Alexandrium have been well studied scientifically, leading to major advances in our understanding of their biogeography, genetics, toxinology, physiology, ecology and management. Here we present a review of the Alexandrium genus, focusing on the major toxic or harmful species. Space limitations preclude a comprehensive review of all aspects of all species in this large genus. Instead, examples are provided of research results and observations that are broadly informative or that are indicative of 
Table 1

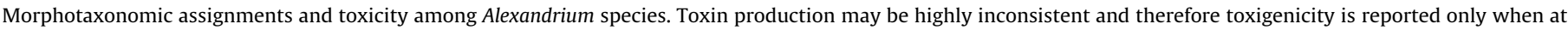
least one strain of the species is known to produce the designated toxin.

\begin{tabular}{|c|c|c|c|c|}
\hline Species & Basionyms/synonyms & First description & Toxin type & Comments \\
\hline $\begin{array}{l}\text { Alexandrium acatenella }{ }^{\mathrm{a}} \\
\text { (Whedon \& Kofoid) Balech }\end{array}$ & $\begin{array}{l}\text { Gonyaulax acatenella Whedon \& } \\
\text { Kofoid } \\
\text { Protogonyaulax acatenella (Whedon } \\
\text { \& Kofoid) Taylor } \\
\text { Gessnerium acatenellum (Whedon \& } \\
\text { Kofoid) L.Loeblich \& Loeblich III }\end{array}$ & $\begin{array}{l}\text { Whedon and } \\
\text { Kofoid (1936) }\end{array}$ & Saxitoxins & $\begin{array}{l}\text { Toxin type assumed only from } \\
\text { mouse bioassay symptoms of } \\
\text { shellfish toxicity associated with } \\
\text { blooms }\end{array}$ \\
\hline $\begin{array}{l}\text { Alexandrium affine } \\
\quad \text { (Inoue \& Fukuyo) Balech }\end{array}$ & $\begin{array}{l}\text { Protogonyaulax affinis Inoue \& } \\
\text { Fukuyo } \\
\text { Alexandrium fukuyoi Balech }\end{array}$ & Fukuyo et al. (1985) & Saxitoxins & Typically low toxicity or non-toxic \\
\hline Alexandrium andersonii Balech ${ }^{\mathrm{a}}$ & & Balech (1990) & Saxitoxins & Most commonly non-toxic \\
\hline $\begin{array}{l}\text { Alexandrium } \\
\quad \text { angustitabulatum }{ }^{\mathrm{a}} \text { Taylor }\end{array}$ & Possible synonym of $A$. minutum & $\begin{array}{l}\text { Balech (1995) } \\
\text { (Hansen et al., 2003) }\end{array}$ & Saxitoxins & $\begin{array}{l}\text { Strains from the type locality } \\
\text { weakly toxigenic }\end{array}$ \\
\hline $\begin{array}{l}\text { Alexandrium balechii }{ }^{\mathrm{a}, \mathrm{b}} \\
\quad \text { (Steidinger) Balech }\end{array}$ & $\begin{array}{l}\text { Gonyaulax balechii Steidinger } \\
\text { Gessnerium balechii (Steidinger) } \\
\text { Loeblich III \& Loeblich, } 1979 \\
\text { Pyrodinium balechii (Steidinger) } \\
\text { Taylor, } 1976\end{array}$ & Steidinger (1971) & None known & $\begin{array}{l}\text { Blooms coincident with mass fish } \\
\text { mortalities in type locality probably } \\
\text { due to oxygen depletion }\end{array}$ \\
\hline $\begin{array}{l}\text { Alexandrium camurascutulum } \\
\text { MacKenzie \& Todd }\end{array}$ & & $\begin{array}{l}\text { MacKenzie and } \\
\text { Todd (2002) }\end{array}$ & None known & \\
\hline $\begin{array}{l}\text { Alexandrium catenella } \\
\text { (Whedon \& Kofoid) Balech }\end{array}$ & $\begin{array}{l}\text { Protogonyaulax catenella (Whedon \& } \\
\text { Kofoid) Taylor } \\
\text { Gessnerium catenellum (Whedon \& } \\
\text { Kofoid) Loeblich \& Loeblich } \\
\text { Gonyaulax catenella Whedon \& } \\
\text { Kofoid }\end{array}$ & $\begin{array}{l}\text { Whedon and } \\
\text { Kofoid (1936) }\end{array}$ & Saxitoxins & \\
\hline $\begin{array}{l}\text { Alexandrium cohorticula } \\
\text { (Balech) Balech }\end{array}$ & $\begin{array}{l}\text { Gonyaulax cohorticula Balech } \\
\text { Protogonyaulax cohorticula (Balech) } \\
\text { Taylor } \\
\text { Gessnerium cohorticula (Balech) L. } \\
\text { Loeblich \& Loeblich III }\end{array}$ & Balech (1967) & Saxitoxins & $\begin{array}{l}\text { Japanese strains reportedly } \\
\text { toxigenic, but possible } \\
\text { misidentification of } A . \\
\text { tamiyavanichii }\end{array}$ \\
\hline $\begin{array}{l}\text { Alexandrium compressum } \\
\text { (Fukuyo, Yoshida \& Inoue) } \\
\text { Balech }\end{array}$ & $\begin{array}{l}\text { Protogonyaulax compressa Fukuyo, } \\
\text { Yoshida \& Inoue }\end{array}$ & Fukuyo et al. (1985) & None known & \\
\hline $\begin{array}{l}\text { Alexandrium concavum } \\
\text { (Gaarder) Balech emend. } \\
\text { Larsen \& Nguyen-Ngoc }\end{array}$ & Goniodoma concavum Gaarder & $\begin{array}{l}\text { Gaarder (1954) } \\
\text { Larsen and } \\
\text { Nguyen-Ngoc (2004) }{ }^{c}\end{array}$ & None known & \\
\hline Alexandrium foedum ${ }^{\mathrm{a}, \mathrm{b}}$ Balech & & Balech (1990) & None known & \\
\hline $\begin{array}{l}\text { Alexandrium fraterculus }{ }^{\mathrm{a}} \\
\quad \text { (Balech) Balech }\end{array}$ & $\begin{array}{l}\text { Gonyaulax fratercula Balech } \\
\text { Gessnerium fraterculum (Balech) } \\
\text { Loeblich \& Loeblich III } \\
\text { Protogonyaulax fratercula (Balech) } \\
\text { Taylor }\end{array}$ & Balech (1964) & None known & \\
\hline $\begin{array}{l}\text { Alexandrium fundyense } \\
\text { Balech }\end{array}$ & & Balech (1985) & Saxitoxins & \\
\hline $\begin{array}{l}\text { Alexandrium gaarderae } \\
\text { Nguyen-Ngoc \& Larsen }\end{array}$ & $\begin{array}{l}\text { Gonyaulax concava (Gaarder) Balech } \\
\text { Alexandrium concavum (Gaarder) } \\
\text { Balech }\end{array}$ & $\begin{array}{l}\text { Larsen and } \\
\text { Nguyen-Ngoc (2004) }\end{array}$ & None known & \\
\hline $\begin{array}{l}\text { Alexandrium globulum } \\
\text { Nguyen-Ngoc \& Larsen }\end{array}$ & & $\begin{array}{l}\text { Larsen and } \\
\text { Nguyen-Ngoc } \\
\text { (2004) }\end{array}$ & None known & \\
\hline $\begin{array}{l}\text { Alexandrium hiranoi } \\
\text { Kita \& Fukuyo }\end{array}$ & $\begin{array}{l}\text { Goniodoma pseudogoniaulax } \\
\text { Biecheler sensu Kita, Fukuyo, Tokuda } \\
\text { \& Hirano (1985) }\end{array}$ & $\begin{array}{l}\text { Kita and Fukuyo } \\
\text { (1988) }\end{array}$ & Goniodomins & \\
\hline $\begin{array}{l}\text { Alexandrium } \\
\quad \text { insuetum }^{\mathrm{a}, \mathrm{b}} \text { Balech }\end{array}$ & & Balech (1985) & None known & \\
\hline $\begin{array}{l}\text { Alexandrium kutnerae } \\
\text { (Balech) Balech }\end{array}$ & Gonyaulax kutnerae Balech & Balech (1979) & None known & \\
\hline Alexandrium leei ${ }^{\mathrm{a}}$ Balech & & Balech (1985) & None known & $\begin{array}{l}\text { Typically non-toxic, but low level of } \\
\text { saxitoxin derivative reported from } \\
\text { Vietnamese strain; unknown } \\
\text { ichthyotoxins }\end{array}$ \\
\hline Alexandrium margalefii ${ }^{\mathrm{a}, \mathrm{b}}$ Balech & & Balech (1994) & None known & \\
\hline Alexandrium minutum ${ }^{\mathrm{a}}$ Halim & $\begin{array}{l}\text { Alexandrium ibericum Balech } \\
\text { Alexandrium lusitanicum Balech } \\
\text { Pyrodinium minutum (Halim) Taylor }\end{array}$ & $\begin{array}{l}\text { Halim }(1960) \\
\text { Balech }(1989)^{c}\end{array}$ & Saxitoxins & $\begin{array}{l}\text { Non-toxic strains also occur, e.g. in } \\
\text { the Mediterranean Sea }\end{array}$ \\
\hline $\begin{array}{l}\text { Alexandrium monilatum }{ }^{\mathrm{a}, \mathrm{b}} \\
\text { (Howell) Balech }\end{array}$ & $\begin{array}{l}\text { Gonyaulax monilata Howell } \\
\text { Gessnerium mochimaensis Halim } \\
\text { Gessnerium monilata (Howell) } \\
\text { Loeblich III } \\
\text { Pyrodinium monilatum (Howell) } \\
\text { Taylor }\end{array}$ & Howell (1953) & Goniodomins & Strongly ichthyotoxic \\
\hline
\end{tabular}


Table 1 (Continued)

\begin{tabular}{|c|c|c|c|c|}
\hline Species & Basionyms/synonyms & First description & Toxin type & Comments \\
\hline $\begin{array}{l}\text { Alexandrium ostenfeldii }{ }^{\mathrm{a}} \\
\quad \text { (Paulsen) Balech \& Tangen }\end{array}$ & $\begin{array}{l}\text { Goniodoma ostenfeldii Paulsen } \\
\text { Gonyaulax ostenfeldii (Paulsen) } \\
\text { Paulsen } \\
\text { Heteraulacus ostenfeldii (Paulsen) } \\
\text { Loeblich III } \\
\text { Gessnerium ostenfeldii (Paulsen) } \\
\text { Loeblich III \& L.A. Loeblich } \\
\text { Triadinium ostenfeldii (Paulsen) } \\
\text { Dodge } \\
\text { Pyrodinium phoneus Woloszynska \& } \\
\text { Conrad } \\
\text { Gonyaulux tamarensis var. globosa } \\
\text { Braarud } \\
\text { Gonyaulax globosa (Braarud) Balech } \\
\text { Gonyaulax trygvei Parke } \\
\text { Protogonyaulax globosa (Braarud) } \\
\text { Taylor }\end{array}$ & $\begin{array}{l}\text { Paulsen (1904) } \\
\text { Balech and Tangen } \\
(1985)^{\mathrm{c}}\end{array}$ & $\begin{array}{l}\text { Spirolides; } \\
\text { saxitoxins }\end{array}$ & $\begin{array}{l}\text { Strains tend to produce either } \\
\text { saxitoxins or spirolides, but rarely } \\
\text { both groups }\end{array}$ \\
\hline $\begin{array}{l}\text { Alexandrium peruvianum }^{\mathrm{a}} \\
\text { (Balech \& Mendiola) } \\
\text { Balech \& Tangen }\end{array}$ & $\begin{array}{l}\text { Gonyaulax peruviana Balech \& } \\
\text { Mendiola }\end{array}$ & $\begin{array}{l}\text { Balech and de } \\
\text { Mendiola (1977) }\end{array}$ & Spirolides & $\begin{array}{l}\text { Spirolides produced by strains from } \\
\text { the Mediterranean Sea }\end{array}$ \\
\hline $\begin{array}{l}\text { Alexandrium pseudogonyaulax }{ }^{\mathrm{a}, \mathrm{b}} \\
\text { (Biecheler) Horiguchi } \\
\text { ex Yuki \& Fukuyo }\end{array}$ & $\begin{array}{l}\text { Goniodoma pseudogonyaulax } \\
\text { Biecheler }\end{array}$ & Biecheler (1952) & & \\
\hline $\begin{array}{l}\text { Alexandrium satoanum } \\
\text { Yuki \& Fukuyo }\end{array}$ & & $\begin{array}{l}\text { Yuki and } \\
\text { Fukuyo (1992) }\end{array}$ & & \\
\hline $\begin{array}{l}\text { Alexandrium tamarense } \\
\text { (Lebour) Balech }\end{array}$ & $\begin{array}{l}\text { Gonyaulax tamarensis Lebour } \\
\text { Gessnerium tamarensis (Lebour) } \\
\text { Loeblich III \& A.L. Loeblich } \\
\text { Protogonyaulax tamarensis (Lebour) } \\
\text { F.J.R.Taylor } \\
\text { Gonyaulax tamarensis var. excavata } \\
\text { Braarud } \\
\text { Gonyaulax excavata (Braarud) } \\
\text { Balech } \\
\text { Protogonyaulax excavata (Braarud) } \\
\text { F.J.R.Taylor } \\
\text { Alexandrium excavatum (Braarud) } \\
\text { Balech \& Tangen }\end{array}$ & Lebour (1925) & Saxitoxins & $\begin{array}{l}\text { Non-toxic strains also occur; } \\
\text { undefined allelochemicals/ } \\
\text { ichthyotoxins may be produced }\end{array}$ \\
\hline $\begin{array}{l}\text { Alexandrium tamiyavanichii }{ }^{\text {a }} \\
\text { Balech }\end{array}$ & & Balech (1994) & Saxitoxins & \\
\hline $\begin{array}{l}\text { Alexandrium tamutum } \\
\text { Montresor, Beran \& John }\end{array}$ & & Montresor et al. (2004) & None known & \\
\hline Alexandrium taylori ${ }^{\mathrm{a}, \mathrm{b}}$ Balech & & Balech (1994) & Saxitoxins & $\begin{array}{l}\text { Usually non-toxic, but also known } \\
\text { to produce non-proteinaceous } \\
\text { exotoxin }\end{array}$ \\
\hline Alexandrium tropicale ${ }^{\mathrm{a}}$ Balech & & Balech (1971) & None known & \\
\hline
\end{tabular}

a Species for which a detailed description accompanied with drawings is available in Balech (1995).

b Species assigned to the subgenus Gessnerium.

c Marks additional references that might be considered for species identification and/or for the clarification of their taxonomy.

approaches leading to improved understanding of other species. One focus is on autecological features that underlie many Alexandrium blooms, based predominantly on the small number of species that have been well studied in the laboratory and the field. Another key issue is life cycle transformations and their quantitative effect on bloom dynamics because in this specific area Alexandrium blooms have been especially well-characterized and differences from other $\mathrm{HAB}$ taxa become apparent. Another unique attribute is that Alexandrium genetics have received considerable attention, both from a phylogenetic perspective, and in terms of identifying genes and gene expression patterns for critical pathways, such as that for toxin production.

\section{Alexandrium species}

\subsection{Taxonomy and phylogeny of Alexandrium}

The genus Alexandrium was formally established with the description of its type species Alexandrium minutum Halim (1960), a small-sized dinoflagellate that produced a 'red tide' in the harbor of Alexandria in Egypt. This genus now includes 31 species (Table 1), many of them originally described under a different genus name (as Gonyaulax, Protogonyaulax, Gessnerium, Goniodoma, and Pyrodinium). This fact reflects the intricate taxonomic history of these species, as well as subjective interpretations of the stability and importance of particular morphological characters for the delineation of genera and species. From the morphological point of view, the species now included in the genus Alexandrium share a Kofoidean plate pattern of APC (apical pore complex), 4', 6", 5"', 2'"', 6C, 9-10S (Balech, 1995). Cells are relatively featureless when observed by light microscopy but minor morphological characters become visible after staining and dissection of thecal plates and/or after examination by scanning electron microscopy. Morphological characters for species identification are: cell size, shape, chain formation, ornamentation of the theca, cingular and sulcal excavation, sulcal lists, shape of APC, $1^{\prime}, 6^{\prime \prime}$ and some sulcal plates, such as S.p., S.a., and S.s.a. A detailed illustration, description and discussion of the various species are presented in the monograph by Balech (1995). Resting cysts have been described for many Alexandrium species and, with the exception of A. pseudogonyaulax, which forms cysts with a distinct paratabulation (Montresor, 1995), they have a smooth wall and a round, oval, or elliptical shape (Matsuoka and Fukuyo, 2003). 
The genus Alexandrium is subdivided into two subgenera: Alexandrium sensu strictu (where the $1^{\prime}$ plate is connected to the APC) and Gessnerium (where the $1^{\prime}$ plate is not connected to the APC; Table 1). When he established the two sub-genera, Balech (1995) already recognized that Gessnerium is a heterogeneous group composed of morphologically distinct species.

Molecular phylogenetic analyses - mostly carried out on genes of the ribosomal RNA (rDNA) in unicellular eukaryotes (including dinoflagellates) - confirmed that Alexandrium belongs to the Gonyaulacales (e.g., Saldarriaga et al., 2004). Sequence analyses of members of the genus Alexandrium support the taxonomic distinction from other gonyaulacoid genera by unequivocally corroborating the monophyletic nature of the genus (e.g., Usup et al., 2002; John et al., 2003b; Saldarriaga et al., 2004). Only a single publication on Alexandrium phylogeny suggested a paraphyletic nature of the genus because large ribosomal subunit (LSU) rDNA sequences of Pyrodinium bahamense diverged from within a clade otherwise exclusively composed of Alexandrium species (Leaw et al., 2005). Though these findings have not been explicitly contested prior to the present review, paraphyly of Alexandrium must be doubted as some inconsistencies with previous studies can be observed in the phylogenetic tree presented by Leaw et al. (2005). Moreover, neither the maximum likelihood - nor the maximum parsimony - based analysis in Leaw et al. (2005; Fig. $3(\mathrm{~A})$ and (B), respectively) give statistical support for paraphyly of Alexandrium. Our phylogenetic analyses, including LSU rDNA sequences of the majority of the currently recognized Alexandrium species and sequences of $P$. bahamense used by Leaw et al. (2005), support the reciprocal monophyly of the two genera (Fig. 1). The close phylogenetic proximity of Pyrodinium to Alexandrium remains uncontested, as this is consistent with the prior taxonomic assignment to Pyrodinium of several species that now belong to Alexandrium (Table 1).

The phylogenetic analyses conducted for this review (Fig. 1) identify several well-supported clades in the genus Alexandrium, although DNA sequences are not available for all members of the two subgenera (e.g., the Gessnerium group species A. balechii and $A$. foedum). In any case, as reciprocal monophyly is not found for the subgenera Alexandrium and Gessnerium, molecular phylogenies do not fully corroborate this taxonomic division of the genus as proposed by Balech (1995). In fact, whereas A. hiranoi, A. monilatum, A. pseudogonyaulax, A. saotanum and $A$. taylori consistently form a well-supported clade that diverges early from all species of the subgenus Alexandrium, two species of the subgenus Gessnerium (A. margalefii and Alexandrium insuetum) do not fall into this clade (Hong et al., 2008; Touzet et al., 2008a,b; Fig. 1). Alexandrium margalefii either shows affinity to this clade with low support (Kim et al., 2005) or relates with only weak to moderate support to a clade including A. minutum, A. angustitabulatum, $A$. tamutum and the $A$. ostenfeldii/A. peruvianum species complex, where it branches off early (John et al., 2003b; Kim et al., 2005; Touzet et al., 2008a). A. insuetum is instead consistently placed within this latter clade (e.g., Hansen et al., 2003; Leaw et al., 2005; Penna et al., 2008; Kremp et al., 2009). While the subgeneric classification by morphological criteria for the majority of Gessnerium species seems evolutionarily meaningful, at least in A. insuetum, plate characteristics have been suggested to result from convergent evolution (Touzet et al., 2008a).

A close phylogenetic relationship is confirmed for the morphologically defined species Alexandrium tamarense, A. fundyense, A. catenella, A. affine, A. tamiyavanichii, A. cohorticula, A. tropicale and $A$. fraterculus. The first three and the latter four species form distinct clusters, respectively. The branching pattern of $A$. affine sequences and these two clades differs depending upon the phylogenetic approach and sequences used for the analysis (e.g., Touzet et al., 2008a,b) and statistical support for either of the possible branching patterns is low. All species of this larger clade are potentially harmful due to their capacity for PSP toxin production and have been the focus of many studies that included morphological and genetic characterization of strains of different geographical origin. These studies highlighted the existence of species-complexes, such as the A.tamarense/catenella/fundyense group, i.e., genetically distinct clusters of strains sharing very similar morphological features.

The three morphospecies A. tamarense, A. catenella and A. fundyense were distinguished based on different combinations of two main characters: the capability to form chains and the presence/absence of a ventral pore between Plates $1^{\prime}$ and $4^{\prime}$. Due to the lack of match and inconsistencies between morphological discrimination characters, toxicity, and genetic resolution among the three species, they were thus grouped within the 'A. tamarense species complex' (Anderson et al., 1994; Scholin et al., 1994). Five ribotypes were identified and named after the geographical origin of the strains: North American, Western European, Temperate Asian, Tasmanian, and Tropical Asian (Scholin et al., 1994). In a subsequent study, a new non-toxic endemic Mediterranean ribotype of $A$. tamarense was described and phylogenetic analyses showed that the isolate identified as A.tamarense Tropical Asian ribotype does not belong to the species complex (John et al., 2003b). A recent study that included gene sequence analysis on a worldwide basis confirmed the clustering of ribotypes into five phylogenetically well-supported clades, exclusively including either toxic or non-toxic strains (Lilly et al., 2007). As this study indicated that the geographic distinctions are no longer indicative of the range occupied by members of each group, a group numbering scheme was introduced to replace geographically referenced clade designations (Fig. 1).

Furthermore, morphological distinction of isolates of the different ribotypes shows that phylogenetic clades are not reciprocally monophyletic. This lack of correlation of morphological and molecular characters indicates that the taxonomic distinction of the species A. tamarense, A. catenella and A. fundyense does not reflect the evolutionary relationship within the species complex. Recent studies on reproductive traits of members of the complex support the notion that the evolutionary units as discerned by rDNA analyses are valid species according to a biological species concept (Brosnahan et al., 2010). In that study, isolates from different ribotypes were shown to be reproductively non-compatible by producing only non-viable zygotes (for the reproductive cycle of Alexandrium, see below).

Comparable findings have been obtained with other morphospecies. Isolates originally described as A. angustitabulatum and $A$. lusitanicum were found to be part of a species complex together with A. minutum (Franco et al., 1995; Hansen et al., 2003; Lilly et al., 2005). The analysis of globally distributed strains of the A. minutum species complex confirmed the identification of a distinct 'Pacific clade' clustering strains from New Zealand and a larger 'global clade' including both toxic and non-toxic strains, within which microsatellite markers revealed geographic structuring (McCauley et al., 2009). Alexandrium andersonii - the fourth member of the $A$. minutum group in the classification proposed by Balech (1995) does not cluster close to the $A$. minutum clade, but rather in a clade with A. ostenfeldii - A. peruvianum (e.g., Hansen et al., 2003; Touzet et al., 2008a) or branches off earlier (e.g., Penna et al., 2008; this study, Fig. 1), although overall support for any of these groupings is usually weak.

A. ostenfeldii and A. peruvianum are morphologically very similar, but can be separated based on their cell size, on the shape of the S.a. platelet, and the right anterior margin of the $1^{\prime}$ plate (Balech, 1995). However, these characters showed considerable variation and overlapping in strains isolated from the Baltic Sea. Moreover, although the geographic coverage of the analyzed 


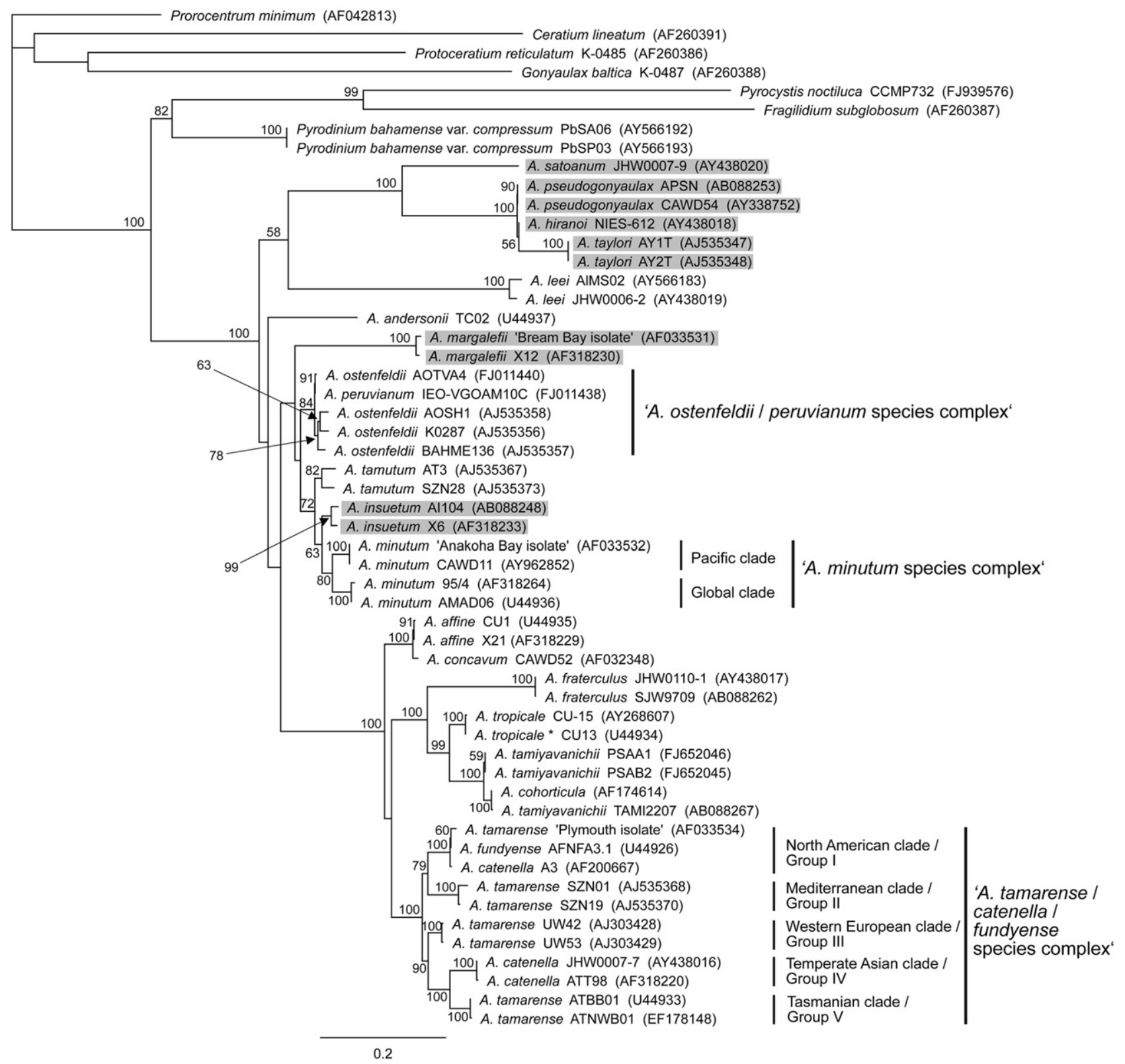

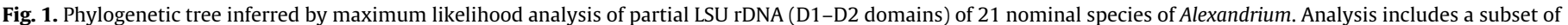

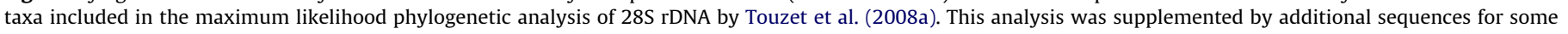

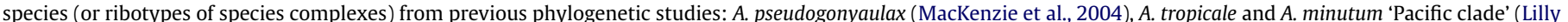

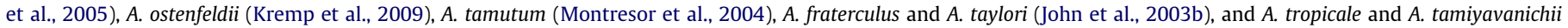

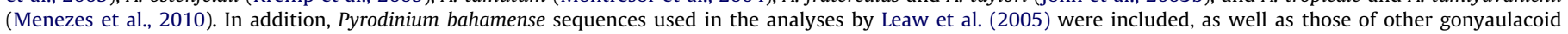

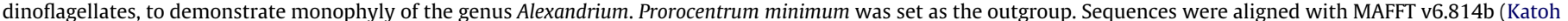

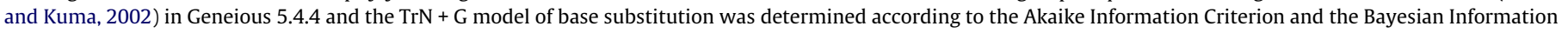

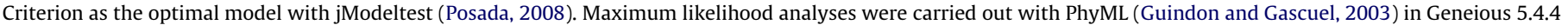

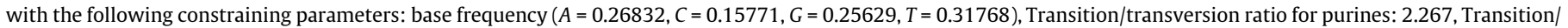

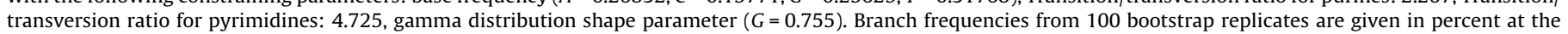

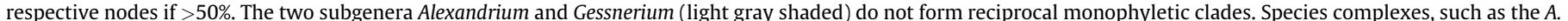

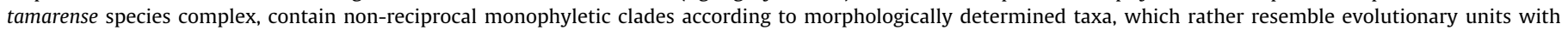
distinct biogeographical distributions and varying degrees of morphological plasticity. *Isolate was originally misidentified as A. tropicale (Lilly et al., 2007).

strains is still limited, there is evidence for the presence of distinct genotypes, possibly cryptic species (Kremp et al., 2009). Similar findings have been obtained with $A$. tamiyavanichii and $A$. cohorticula. Again, detailed analysis of strains showed a broad range of characters that does not support their separation into distinct species (Lim et al., 2007; Menezes et al., 2010).

In the genus Alexandrium, as for many other protist taxa, the advent of molecular techniques challenged the classification of species based on morphological characters by showing that: (i) a high level of genetic diversity is present within the same morphospecies, and (ii) some characters for separation of closely related morphospecies show a broad range of variability and do not match molecular genetic clustering.

Morphological and genetic examination of strains obtained from different geographical locations, including the type locality of the different morphospecies, is required to formally re-define several species. Within Alexandrium it might be possible to identify 'speciescomplexes' that share some morphological characters. These complexes, however, will include a higher level of diversity that we now perceive as cryptic species (i.e., the $A$. tamarense ribotypes 
and clades within A. minutum) or distinct populations (e.g., the different population subclusters within A. minutum or A. catenella/ Group IV as discriminated by microsatellite markers). Perhaps these are the 'units' to track if we are to understand the evolutionary history and dispersion patterns of these dinoflagellates.

One striking example that underlines the necessity of acknowledging molecular characters is the existence of strictly toxic and non-toxic ribotypes within the A. tamarense species complex (Scholin et al., 1994; Lilly et al., 2007). No consensus, however, has been reached on how to reconcile the molecular divergence of clades within species complexes with respect to the taxonomic validity of described species and the potential necessity to define new species on the basis of molecular or other hitherto unrecognized characters. The development of a comprehensive species concept for Alexandrium that acknowledges phylogenetic differences among evolutionary lineages would certainly provide benefits for research, as distinctly evolved phylogenetic lineages might differ substantially with respect to their ecological niches and bloom characteristics.

\subsection{Species identification and discrimination}

Members of the genus Alexandrium are among the most difficult $\mathrm{HAB}$ taxa for species identification because of the subtle morphological characteristics used for classification, many of which are not easily resolved during monitoring or research programs. Furthermore, as exemplified by the $A$. tamarense species complex, chain-forming ability, thecal tabulation and cell shape (Balech, 1995) are considered by some to be plesiomorphic features that are not reliable taxonomic markers (John et al., 2003b; Leaw et al., 2005). Morphologically intermediate forms have been observed under different environmental conditions both in culture and in the field (e.g., Anderson et al., 1994), and toxic and non-toxic ribotypes of the same morphologically defined species sometimes co-occur (e.g., Touzet et al., 2009; Brosnahan et al., 2010). Over the last few decades, the introduction of a variety of molecular methods has made possible the discovery of an incredible and unsuspected diversity within phytoplankton communities, including within the genus Alexandrium.

A common approach taken with Alexandrium species involves the development of species- or intra-specific molecular "probes" that can label cells of interest so they can be detected visually, electronically, or chemically. Progress has been rapid and probes and assays of multiple types are already available for many species and distinct ribotypes (i.e., potential cryptic species). Although cell-surface antibodies have been used, the most promising approach involves short pieces of synthetic DNA (probes or primers) that bind to complementary portions of target molecules in the corresponding HAB species (Tables 2 and 3). These molecular targets, typically ribosomal RNA (rRNA), can be visualized and/or quantified by a variety of techniques such as fluorescent in situ hybridization (FISH); sandwich hybridization assays (SHA), and a variety of PCR-based assays described below. These developments have reached the stage where the new molecular counting methods are routinely employed in some research (e.g., Anderson et al., 2005b) and monitoring programs.

\subsubsection{Amplification/sequencing-based methods}

rRNA genes have been widely used for identification and enumeration, as well as for phylogenetic studies in Alexandrium (Table 2). Scholin and Anderson $(1994,1996)$ were the first to use rRNA genes (small subunit or SSU, 18S rRNA; large subunit or LSU, $28 \mathrm{~S}$ rRNA) for Alexandrium identification and classification in a large-scale restriction fragment-length polymorphism (RFLP) study that especially targeted species- and group-specific sequence differences in these genes.
Among the ribosomal genes, the D1/D2 region of LSU rDNA has also revealed evolutionary relationships and species boundaries within the A. minutum group (Lilly, 2003), and thus it has been the basis of numerous identification and biogeographical studies worldwide (Lilly et al., 2002; MacKenzie et al., 2004; Ruiz Sebastián et al., 2005; Menezes et al., 2010). Similarly, multiplex PCR assays have been developed, based upon primers designed from the D1/ D2 and ITS regions, for the simultaneous detection and quantification of Alexandrium species coexisting in French and Japanese waters (Guillou et al., 2002; Genovesi et al., 2011; Nagai, 2011) and Alexandrium cysts in bottom sediments (Erdner et al., 2010).

The rRNA gene has also been used for quantification of Alexandrium cells, such as those of $A$. minutum, by addressing the 5.8S rDNA from both preserved environmental samples and cultures (Galluzzi et al., 2004). However, it was recently shown that rRNA gene copy number significantly varies even among Alexandrium species, and at least within A. taylori also according to growth phase (Galluzzi et al., 2010; Brosnahan et al., 2010). This is a critical consideration when applying quantitative PCR-based techniques for cell enumeration.

Mitochondrial markers have recently emerged as a powerful alternative for species discovery and identification. Under the name of DNA barcoding, these markers, such as the cytochrome $\mathrm{c}$ oxidase subunit 1 , are used to discriminate unidentified taxa and to assign them to species. However, when applied for the investigation of dinoflagellate diversity, DNA barcoding with mitochondrial markers failed to resolve strains belonging to the genus Alexandrium (e.g., Lin et al., 2009; Stern et al., 2010).

\subsubsection{Hybridization-based methods}

Hybridization protocols based upon taxon-specific molecular probes targeting rDNA regions have also been developed to enable the rapid detection of individual Alexandrium species using FISH, SHA, or PCR-based assays (Table 3). This work has been especially productive for the $A$. tamarense species complex, as well as for $A$. minutum and $A$. ostenfeldii (e.g., Penna and Magnani, 1999; Metfies et al., 2005; John et al., 2005; Diercks et al., 2008; Gescher et al., 2008; Touzet et al., 2010; Erdner et al., 2010).

DNA microarrays (or "chips") allow the simultaneous analysis of several target genes or taxa in a single experiment, and as such represent a useful tool for studying complex phytoplankton communities. The ALEX CHIP (Gescher et al., 2008) was the first prototype developed for the detection of several Alexandrium species. The newly developed biosensor ALGADEC (Diercks-Horn et al., 2011) enabled the detection of $A$. minutum in a semiautomated fashion. In this regard, it appears as a promising device for the study of HABs. The possibility of combining multiple probes targeting multiple species makes this sensor, and related multiplex instruments (e.g., Scholin et al., 2009), an effective approach for detection and quantification of toxic algae in the field.

\subsection{Biogeography and evolution}

Members of the genus Alexandrium are widespread globally, with species present in coastal, shelf and slope waters of subarctic, temperate and tropical regions of the Northern and Southern Hemispheres (Taylor et al., 1995; Lilly et al., 2007). The diversity of Alexandrium appears to be higher in the Mediterranean Sea than elsewhere, but this may reflect the level of taxonomic scrutiny more than an actual distribution. For illustration, twelve distinct species (including three ribotypes of the $A$. tamarense species complex) have been identified so far from this regional sea (Penna et al., 2008; Fig. 2). The $A$. tamarense species complex appears to be the most widely dispersed and occurs in many locations worldwide, covering all ocean basins and many regional seas (Lilly et al., 2007). On the 
Table 2

Primer sequences for ribosomal RNA genes of Alexandrium species.

\begin{tabular}{|c|c|c|c|c|}
\hline Target gene/marker & Target taxa & Primer name & $5^{\prime}-3^{\prime}$ sequence & Reference \\
\hline \multicolumn{5}{|l|}{ Ribosomal RNA genes } \\
\hline \multirow[t]{2}{*}{ 28S rRNA } & Dinophyceae & D1R & ACCCGCTGAATITAAGCATA & Scholin et al. (1994) \\
\hline & & $\mathrm{D} 2 \mathrm{C}$ & CTTGGTCCGTGTTTCAAGA & \\
\hline \multirow[t]{5}{*}{ 28SrRNA } & Alexandrium species & Alex1(r) & ACCACCСАCТTTGCATTCCA & Guillou et al. (2002) \\
\hline & Alexandrium catenella (TA clade) & Acat1(r) & GCACTACAATCTCACTGAGG & \\
\hline & Alexandrium catenella (NA clade) & Acat3(r) & AAGTGCAACACTCCCACCAA & \\
\hline & Alexandrium minutum & $\operatorname{Amin} 2(r)$ & AGCACTGATGTGTAAGGGCT & \\
\hline & Alexandrium fundyense & (f) & GAATGCAAAGTGGGTGG & Dyhrman et al. (2006) \\
\hline \multirow[t]{8}{*}{ 28S rRNA D1/D2 } & Alexandrium tamarense & Atama-F3 & ACCTTTGCACATGAATGATAAGTC & Nagai (2011) \\
\hline & & Atama-R1 & CATCCCCAAGCACAGGAAC & \\
\hline & Alexandrium catenella & Acat-F3 & CAAAGTAAACAGACTTGATTTCCTC & \\
\hline & & Acat-R2 & GAAAGCAACCTCAAGGACAAG & \\
\hline & Alexandrium fraterculus & Afra-F1 & GCTTTGAATTGTGTTTGTGAAC & \\
\hline & & Afra-R3 & GTCAGTGTTAAAGCTTGTGGG & \\
\hline & Alexandrium pseudogonyaulax & Apseu-F2 & GGGTGGTAAATTTCACGCAAG & \\
\hline & & Apseu-R2 & TGGCAACAGCTGACAATCGCA & \\
\hline \multirow[t]{2}{*}{ 18S rDNA } & Alexandrium monilatum & $1 \mathrm{~F}$ & AACCTGGTTGATCCTGCCAGT & Rogers et al. (2006) \\
\hline & & $1800 \mathrm{R}$ & TCCTTCTGCAGGTTCACCTAC & \\
\hline \multicolumn{5}{|c|}{ ITSs and ribosomal RNA genes } \\
\hline \multirow[t]{2}{*}{ ITS1-5.8S-ITS2 } & Alexandrium & ITSA & CCTCGTAACAAGGCTCCGTAGGT & Adachi et al. (1994) \\
\hline & & ITSB & CAGATGCTAAGTTCAGCA & \\
\hline \multirow[t]{4}{*}{ ITS1-5.8S-ITS2 } & Alexandrium & P1 & GTAGGATCCGGTGAACCTTGCAGAAGGA & Spalter et al. (1997) \\
\hline & & $\mathrm{P} 2$ & ATCGAATTCCTCCGCTTACTTATATGC & \\
\hline & Alexandrium & $5.8 \mathrm{~S}-\mathrm{b} 5^{\prime}$ & YGATGAAGAATGCAGCAAMATG & Galluzzi et al. (2004) \\
\hline & & $5.8 \mathrm{~S}-\mathrm{b} 3^{\prime}$ & CAAGCAHACCTTCAAGMATATCC & \\
\hline \multirow[t]{3}{*}{ ITS1-5.8S-ITS2 } & Alexandrium & $5.8 \mathrm{~S}-5^{\prime}$ & GCAADGAATGTCTTAGCTCAA & Galluzzi et al. (2005) \\
\hline & Alexandrium minutum & ITS1m (f) & CATGCTGCTGTGTTGATGACC & \\
\hline & & $5.8 \mathrm{~S}-3^{\prime}$ & GCAMACCTTCAAGMATATCCC & \\
\hline \multirow[t]{8}{*}{ ITS1-5.8S-ITS2 } & Alexandrium andersonii & $5.8 \mathrm{~S}-5^{\prime}$ & GCAADGAATGTCTTAGCTCAA & Penna et al. (2007) \\
\hline & & ITS2an & GATGACACGTTTCGGCAAG & \\
\hline & Alexandrium catenella & ITS1c & AGCATGATTTGTTTTTCAAGC & \\
\hline & & $5.8 \mathrm{~S}-3^{\prime}$ & GCAMACCTTCAAGMATATCCC & \\
\hline & Alexandrium tamarense & $5.8 \mathrm{~S}-5^{\prime}$ & TGTTACTTGTACCTTTGGGA & \\
\hline & & ITS2t & ACAACACCCAGGTTCAAT & \\
\hline & Alexandrium taylorii & ITS1t & TGGTGTTTGAATGCGGTTGT & \\
\hline & & $5.8 \mathrm{~S}-3^{\prime}$ & GCAMACCTTCAAGMATATCCC & \\
\hline \multirow[t]{2}{*}{ ITS1-5.8S-ITS2 } & Alexandrium taylorii & Tay5' & TGGTGTTTGAATGCGGTTGT & Galluzzi et al. (2010) \\
\hline & & Tay3' & AGGAAATGGCACCAGAATGC & \\
\hline \multirow[t]{3}{*}{ 18S-ITS1-5.8S-ITS2-28S } & Alexandrium catenella & FACAT & TGATATTGTGGGCAACTGTAA & Genovesi et al. (2011) \\
\hline & Alexandrium tamarense & FATAM & TGGTAATTCTTCATTGATTACAATG & \\
\hline & & TACATAM & AACATCTGTTAGCTCACGGAA & \\
\hline \multirow[t]{4}{*}{ ITS } & Alexandrium tamiyavanichii & Atami-F1 & AAGCTTGCTGTGGGTACAGA & Nagai (2011) \\
\hline & & Atami-R1 & TACAGCTCACAGCAATGCAG & \\
\hline & Alexandrium affine & Affn-F1 & CTTGCTTCAAGCTGGTATGTC & \\
\hline & & Affn-R2 & GTCAATGTTCACCATTTCACCA & \\
\hline
\end{tabular}

(f) forward and (r) reverse.

other hand, members of this species complex seem to be largely absent from the equatorial tropics.

Whereas many biogeographical studies of Alexandrium are based upon examination of vegetative cells, the hypnozygotes or cysts are highly resistant to decay and thus facilitate studies of the distribution of some species in modern sediments and their linkages with environmental conditions. Cysts of A. tamarense have been found within a surface water temperature range of

Table 3

Probe sequenes for target ribosomal DNA genes of Alexandrium species.

\begin{tabular}{|c|c|c|c|c|}
\hline Probe name & Target gene & Sequence $\left(5^{\prime}-3^{\prime}\right)$ & Specific for & Reference \\
\hline AOST1 & $18 \mathrm{~S}$ & CAACCCTTCCCAATAGTCAGGT & A. ostenfeldii & Metfies et al. (2005) \\
\hline AOST2 & $18 \mathrm{~S}$ & GAATCACCAAGGTTCCAAGCAG & A. ostenfeldii & Metfies et al. (2005) \\
\hline AOST02 & $18 \mathrm{~S}$ & CACCAAGGTTCCAAGCAG & A. ostenfeldii & John et al. (2003a) \\
\hline ALEXMIN1 & $18 \mathrm{~S}$ & CCCAGAAGTCAGGTTTGGAT & A. minutum (AY831408, AY883006, AJ535380, AJ535388) & Nölte, unpublished \\
\hline Act1 & $28 \mathrm{~S}$ & GCACTTGCAGCCAAAACCCA & A. catenella (Temperate Asian Clade, Group IV) & Sako et al. (2004) \\
\hline ATNA01 & $28 \mathrm{~S}$ & AGTGCAACACTCCCACCA & A. tamarense (North American Clade, Group I) & Miller and Scholin (1998) \\
\hline Atm1 & $28 \mathrm{~S}$ & ACACCCACAGCCCAAAGCTC & A. tamarense (North American Clade, Group I) & Sako et al. (2004) \\
\hline ATAM01 & $28 \mathrm{~S}$ & TTCAAGGCCAAACACCTG & A. tamarense species complex & John et al. (2005) \\
\hline ATNA02 & $28 \mathrm{~S}$ & AАCACTCCСACCAAGCAA & A. tamarense (North American Clade, Group I) & John et al. (2005) \\
\hline ATWE03 & $28 \mathrm{~S}$ & GCAACCTCAAACACATGG & A. tamarense (Western European Clade, Group III) & John et al. (2005) \\
\hline ATME04 & $28 \mathrm{~S}$ & CССССССАСAAGAAACTT & A. tamarense (Mediterranean Clade, Group II) & John et al. (2005) \\
\hline AMINC & $18 \mathrm{~S}$ & GAAGTCAGGTTTGGATGC & A. minutum & Diercks et al. (2008) \\
\hline AMINCNEXT & $18 \mathrm{~S}$ & TAATGACCACAACCCTTCC & A. minutum & Diercks et al. (2008) \\
\hline TamA & $28 \mathrm{~S}$ & TCACCCACAGCCAAAACCTA & A. tamarense (Western European Clade, Group III) & Touzet et al. (2010) \\
\hline TamToxC & $28 \mathrm{~S}$ & GCAAGTGCAACACTCCCACCA & A. tamarense (North American Clade, Group I) & Touzet et al. (2010) \\
\hline
\end{tabular}


-0.6 to $26.8^{\circ} \mathrm{C}$ with the highest relative abundances in regions between 5 and $15^{\circ} \mathrm{C}$. Members of this species complex can be regarded as characteristic of temperate/subtropical regions in brackish to fully marine and oligotrophic to eutrophic environments (Marret and Zonneveld, 2003).

Although many Alexandrium species are known to be widely distributed across several continental coastal and shelf waters, comprehensive distributional data for many regions are still scarce. Hence, the underlying biogeographic constraints and natural distributional patterns remain largely obscure. Nevertheless, for a few species, such as those from the A.tamarense species complex, the observed distributional patterns were seemingly dense enough to formulate an evolutionary model based on vicariance and allopatric speciation to explain the present day distribution as a consequence of plate tectonics, long-term climate variation and related alterations in paleoceanographic conditions (Scholin et al., 1995; John et al., 2003b). In other Alexandrium species, the formation of genetic population structure and eventually the divergence of evolutionary lineages are most likely driven by the same factors. An understanding of differentiated evolutionary lineages with distinct biogeographies in other species or species complexes, such as A. minutum (Lilly et al., 2005; McCauley et al., 2009), A. ostenfeldii (Kremp et al., 2009), A. tamiyavanichii (Menezes et al., 2010), is already emerging. As more detailed studies on these taxa are carried out, common patterns may become prominent for the evolutionary forces shaping Alexandrium species and populations.

Over the last century, these natural processes have been augmented by human activities such as ballast water discharge (e.g., Bolch and de Salas, 2007) or shellfish stock transfers. Some argue that the dramatic increase of recorded $\mathrm{HAB}$ events and changes in their intensity over the last decades are at least partially a consequence of human-mediated range extensions of HAB species, including those of Alexandrium (Hallegraeff, 1993; Maso and Garcés, 2006). One example is seen in the Mediterranean Sea, which harbors a large number of reportedly invasive toxic and non-toxic Alexandrium species. Alexandrium catenella was first reported in the Balearic Islands and Catalonia in 1983 (Margalef and Estrada, 1987), and then appears to have spread in the Western Mediterranean region along the French, Spanish, Italian, Greek and Maghrebian coasts (Abadie et al., 1999; Vila et al., 2001; Lugliè et al., 2003; Frehi et al., 2007; Turki et al., 2007).

The emergence of molecular techniques that enable highresolution genetic characterization of a population will lead to a reexamination of some of these invasion reports. In some cases, species considered as exotic may turn out to be part of a "hidden flora", and their emergence may then be attributed to climate change or to other processes that alter the environment in a way that favors their detection (Smayda, 2007). To this end, polymorphic genetic markers such as DNA microsatellites have been developed for some Alexandrium species (e.g., A. tamarense North American clade/Group I (Nagai et al., 2004; Alpermann et al., 2006), A. minutum (Nagai et al., 2006a), A. catenella Temperate Asian clade/Group IV (Nagai et al., 2006b). An example of the application of these versatile molecular tools is in understanding the sudden appearance of $A$. catenella in Thau Lagoon in the Mediterranean after decades of nondetection during monitoring programs. On the basis of rRNA sequencing, this was argued to be a result of human-assisted introduction (Lilly et al., 2002). However, when Masseret et al. (2009) examined these same strains using hypervariable microsatellite markers, relationships emerged that were not apparent from rRNA studies on the same group. Mediterranean populations were shown to be a distinct lineage and therefore other origins must now be explored.

Detailed analyses of past range extensions and ongoing population differentiation require concerted research efforts with regard to population sampling and method development (e.g., of genetic markers for single-cell genotyping). One such successful effort has been the transregional analysis of population genetic structure of the A. tamarense Group I clade from Japan and Korea (Nagai et al., 2007). Here the degree of genetic differentiation of populations was strongly and positively correlated with geographic distance of sampled populations. However, the observed genetic patterns also allowed identification of some geographically defined populations with deviations from the general model that were most plausibly explained by human mediated interference, e.g., by transfer of $A$. tamarense cells with shellfish stocks.

A recent study that combined genetic models and indirect connectivity, as estimated by oceanographic modeling, showed the existence of a genetic population substructure for $A$. minutum in the Mediterranean Sea (Casabianca et al., 2011). The observed regional genetic structure (i.e., existence of four distinct genotype clusters in their majority formed by isolates from the Adriatic, Ionian, Tyrrhenian or Balearic-Tyrrhenian Sea) was explained by basin-scale transportation patterns through successive generations of vegetative microalgal cells. In contrast to earlier expectations of broad genetic uniformity in planktonic marine microbes, which were based on assumptions of high dispersal capabilities and large population sizes, such strong intraspecific regional genetic patterns might be observed for the majority of Alexandrium species and other microorganisms. This is especially true when complex ecological requirements may pose barriers to dispersal during different stages of their life cycles.

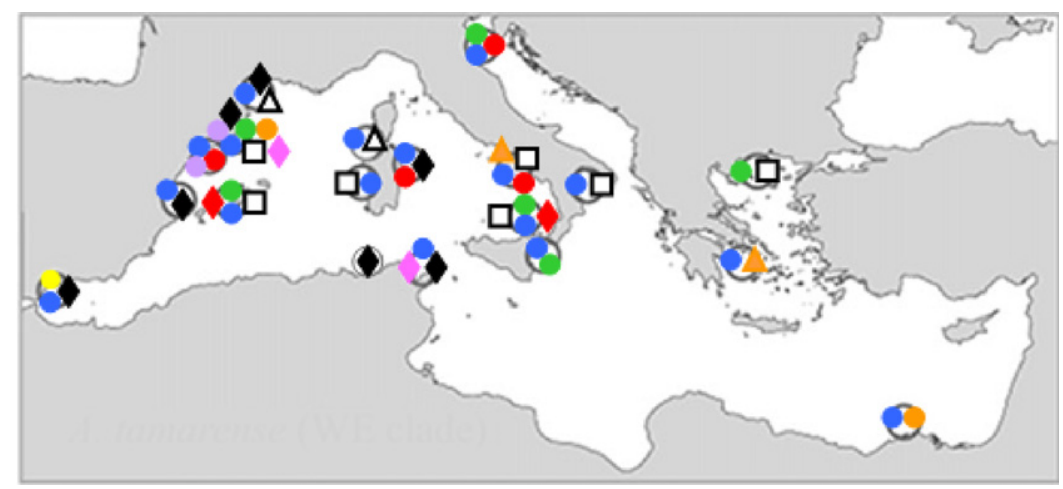

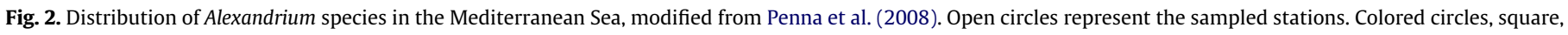

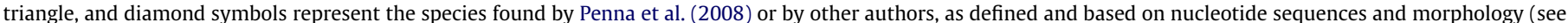

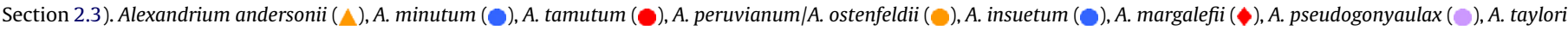
$(\bigcirc)$, A. affine $(\bigcirc)$, A. catenella Group VI $(\diamond)$, A. tamarense Group II $(\square)$, and Group III $(\triangle)$. 
One fascinating aspect of Alexandrium biogeography is the distribution of toxic and non-toxic strains of the same species, or of closely related species. Generally, the distributions do not overlap, as is the case for A. minutum in Ireland, where toxic forms are found in the south, and non-toxic strains in the west (Touzet et al., 2008a). Two known exceptions are the Shetland Islands in Scotland (Touzet et al., 2010), and Belfast Lough in Northern Ireland (Brosnahan et al., 2010). Toxic and non-toxic species within the $A$. tamarense complex have been documented in both locations. A possible explanation for this distinct range separation of toxic and non-toxic strains or species was recently demonstrated by Brosnahan et al. (2010) who mated Group I and Group III strains of $A$. tamarense (toxic and non-toxic, respectively), forming true resting cysts that germinated, but the germling cells could not survive. This reproductive barrier argues that Group I and Group III ribotypes are different biological species and also suggests that biogeographic patterns might be shaped by limited sexual compatibility. Invasions by one type into the range of another may not be successful unless it arrives in overwhelming numbers, because hybridizations are lethal.

\section{Life histories}

\subsection{Life cycle generalities and unique aspects for different species}

The life cycle of Alexandrium species investigated thus far - as that of most protists - includes different stages that have distinct morphology, physiology and function. Although sharing the same genetic material, the cells of different life cycle stages within a population have important and different functions, but the environmental and/or internal signals that induce transition between those stages are still largely unknown (von Dassow and Montresor, 2011). The reconstruction of the general life cycle pattern, i.e., of the different life stages, can be achieved only with laboratory investigations where cultures are studied under different experimental conditions. Nevertheless, in situ studies provide the necessary validation of the experimental approach and are in turn source of new questions for experimental work.

The general scheme of the life cycle of Alexandrium species (Fig. 3) can be summarized as follows. There are, however, various aspects (indicated in parentheses below) that may vary from species to species and even among genetically distinct strains of the same species:

- haploid motile stages (cell division modality; chain formation) - asexual cysts, i.e., pellicle cysts

- haploid gametes (homothallic, heterothallic or complex mating system)

- diploid zygote (fate of the zygote: remains motile, transforms into a long-lived resting cyst, or into a short-term cyst that germinates rapidly)

- diploid non-motile cyst (length of the dormancy period; factors that regulate germination).

\subsubsection{The vegetative phase}

Alexandrium species - as almost all dinoflagellates - are haploid during their vegetative phase; the diploid stages are the planozygote produced following gamete conjugation (Figueroa et al., 2007) and the sexual cyst or hypnozygote. Vegetative cell division usually occurs through desmoschisis (Figueroa et al., 2007), i.e., each daughter cell maintains half the thecal plates of the mother cells, and couplets of recently divided cells are often recorded in actively growing cultures. A phased cell cycle, with maxima of dividing cells recorded shortly before the end of the dark phase, has been reported for A. minutum (Probert et al., 2002).
However, the formation of non-motile division cysts has been reported for three species of the subgenus Gessnerium: A. pseudogonyaulax, A. taylorii and A. hiranoi (Kita et al., 1985; Montresor, 1995; Garcés et al., 1998). In A. pseudogonyaulax, cells cast off thecal plates and flagella and two (or at times four) flagellated daughter cells emerge from the division cyst (Montresor, 1995). In natural populations of $A$. hiranoi (reported as $A$. pseudogonyaulax in Kita et al., 1985), division cysts are produced at the beginning of the dark period. They settle on the sediments and release two flagellated daughter cells after the initiation of the light phase. In A. taylorii, both vegetative division modalities have been reported (Garcés et al., 1998; Giacobbe and Yang, 1999) namely the formation of division cysts, within which 2,4 or 8 cells were produced, and division through desmoschisis. In the natural environment, the formation of division cysts shows some evidence of a daily rhythm, being preferentially restricted to the dark phase (Garcés et al., 1998).

Chain formation is a definable species characteristic that also represents an example of life stage transition within the vegetative phase; the capability to form long chains is reported for several species such as A. catenella, A. affine, A. fraterculus, A. cohorticula, and $A$. tamiyavanichii. Chain formation in $A$. catenella may be stimulated by turbulence (Sullivan et al., 2003), and chain length may decrease in culture, thus suggesting that this feature represents an adaptation to high turbulence upwelling systems. However, this interpretation does not apply to A. catenella isolated from Thau Lagoon (Northern Mediterranean), as strains have a high sensitivity to agitation in culture (Collos et al., 2004). Chains of cells have a faster swimming velocity than single cells (Fraga et al., 1989) and might thus migrate diurnally between the deep nutrient-rich layer and the surface. The capability to switch between single cells and chains might also represent a strategy to reduce grazing.

Another stage transition within the vegetative phase is represented by the formation of pellicle cysts, which are nonmotile cells surrounded by a thin wall (Anderson and Wall, 1978; pellicle cyst terminology reviewed in Bravo et al. (2010)). Pellicle cysts can be formed as a reaction to environmental stress conditions such as turbulence, the presence of parasites, or passage through the gut of grazers. Pellicle cysts have no mandatory maturation period and can revert to the vegetative motile stage once stress conditions are over. The capability to rapidly turn into a pellicle cyst might represent an effective defense strategy against parasite attacks. In fact, when $A$. ostenfeldii was exposed to the parasitic flagellate Parvilucifera infectans or to waterborne cues produced by them, a large fraction of the population became temporary cysts, which were more resistant to parasite infection (Toth et al., 2004).

\subsubsection{The sexual phase}

Gametes of Alexandrium species are either undifferentiated from vegetative cells or are smaller in size. The mechanisms leading to the differentiation of gametes, as well as the modalities of the recognition system between gametes are still unknown. In induction of the sexual phase, conjugation starts after cells pair, facing their ventral side. The appearance of conjugating gametes and formation of larger and biflagellate planozygotes is generally obtained by transferring vegetative cells into diluted $\mathrm{N}$ - or P-deprived culture medium (e.g., Anderson and Lindquist, 1985). However, the difficulty of distinguishing gametes in natural populations limits the possibility to link specific nutritional factors with the onset of the sexual phase. In A. hiranoi, formation of smaller division cysts producing four smaller motile cells has been interpreted as the process leading to the formation of gametes; these smaller cells fuse and produce a biflagellate swimming zygote or 


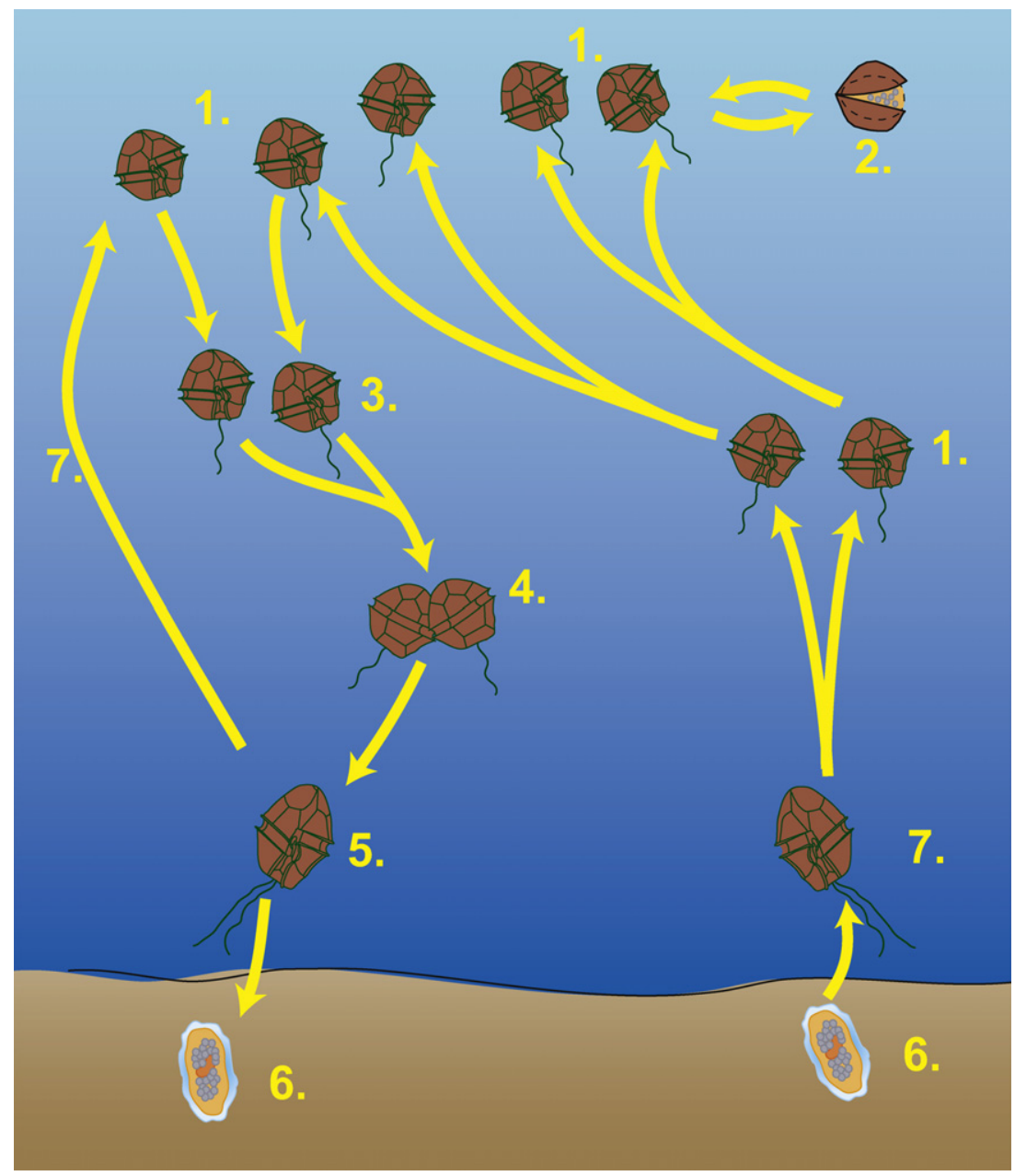

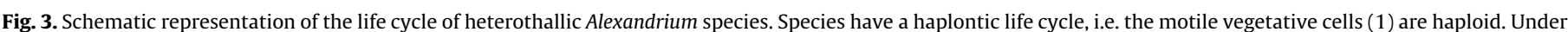

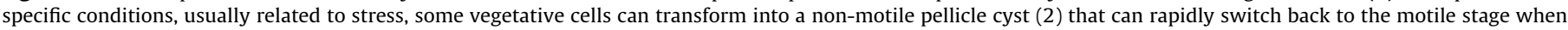

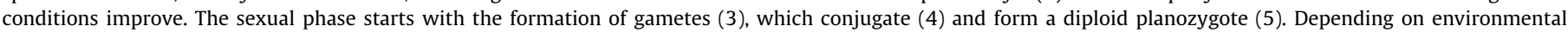

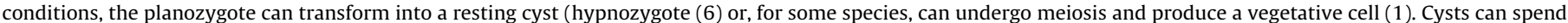
variable periods of time in the sediments and, upon germination, release a motile cell termed a planomeiocyte (7) which divides to produce vegetative cells (1).

planozygote (Kita et al., 1993). The inhibitory effect of concavalin A and tunicamycin on the conjugation process in A. catenella has been interpreted as evidence for agglutinin-like compounds involved in gamete-gamete recognition (Sawayama et al., 1993).

In the last decade, evidence has been provided for a number of cyst-forming dinoflagellate species, including some Alexandrium (A. minutum, A. tamutum (Figueroa et al., 2007) A. taylorii (Figueroa et al., 2006), A. catenella (Figueroa et al., 2005), A. peruvianum (Figueroa et al., 2008a)) that the transition between planozygote and resting cyst is not an obligate one. Furthermore, the planozygote can indeed undergo multiple alternate transitions, depending on environmental conditions. In $A$. taylorii, the planozygote can either undergo cell division to produce two vegetative cells, or transform into a short-term pellicle cyst, or into a long-term resting cyst (Figueroa et al., 2006). When pairing gametes were isolated into different culture media, direct division prevailed in nutrient replete media, whereas the formation of pellicle cysts mainly occurred in P-depleted medium or in diluted medium, and the formation of thick-walled resting cysts was only observed in $\mathrm{N}$-depleted media. However, the response of planozygotes to different nutrient conditions does not follow a consistent pattern among species. In fact, encystment of $A$. catenella planozygotes was high both in $\mathrm{N}$-depleted medium and in nutrient replete conditions (Figueroa et al., 2005). The high production of pellicle cysts observed in P-depleted medium for $A$. taylorii was confirmed, and pellicle cysts were able to germinate into a motile vegetative cell within a few days. A similar life cycle pattern in which the planozygote either divided - when transferred into nutrient-replete medium - or transformed into a short-term pellicle cyst when incubated in $\mathrm{N}$ - or P-depleted medium was described for A. peruvianum (Figueroa et al., 2008a). The formation of sexual resting cysts in this species was observed in culture when mixing strains of opposite mating type, but never observed when individual planozygotes were isolated into different media. This raises the possibility that other factors, such as cell concentration (Uchida, 2001), might play a role in determining the fate of planozygotes.

3.1.2.1. Mating system. The mating system can be assessed by detecting the formation of zygotes in clonal strains, or in pair-wise crosses of clonal strains. In fact, assuming that cysts represent the diploid stage deriving from the fusion of two gametes, the culture resulting from the germination of a cyst contains a mixture of the two parental types. Moreover, evidence for sexual compatibility should be provided by the observation of planozygotes and not only by resting cysts, due to the fact that the two processes might be uncoupled, i.e., planozygotes can be produced but they do not necessarily transform into cysts. Homothallic, heterothallic, and more complex mating systems have been reported within the 
genus Alexandrium. The first mating studies carried out on A. catenella (Yoshimatsu, 1981, 1984) demonstrated a heterothallic mating system, and that the chain of cells produced from the germination of a sexual cyst included two different mating types, i.e., cells in the posterior and anterior half of the chain were different types. In contrast, experiments on monoclonal strains suggested a homothallic system for $A$. affine (Band-Schmidt et al., 2003). The mating system of $A$. tamarense (as A. excavatum) and the reproductive efficiency was investigated by crossing multiple clonal strains and monitoring the presence of fusing gametes, cyst formation and subsequent germination success (Destombe and Cembella, 1990). Both auto-compatible (putatively homothallic) and heterothallic strains were determined, and one strain was capable of crossing with all the others, suggesting that this species has a complex mating system. This system involves a spectrum of mating compatibility rather than two defined mating types, a finding confirmed by Brosnahan et al. (2010).

3.1.2.2. Cyst formation, maturation, and germination. The planozygote formed from gamete fusion can follow different routes, one of which is the formation of hypnozygotic resting cysts, when there is a temporary suspension of germination due to both exogenous and endogenous factors. The length of the maturation period during which germination of newly formed cysts is not possible even under favorable conditions and the factors that induce and modulate encystment and excystment are important in population dynamics. For Alexandrium species studied in the laboratory, encystment has been induced by inoculating strains into culture medium with reduced concentration of $\mathrm{N}$ - or P-nutrients or into diluted media (e.g. Anderson et al., 1984; Figueroa et al., 2005). Besides depleted nutrients, other factors might influence encystment success (see Olli et al. (2004)) for a discussion of methods and terminology to quantify encystment). Cyst production may vary with temperature (e.g., Anderson et al., 1984) and specific bacteria can play a role in inducing or inhibiting encystment in $A$. tamarense (e.g., Adachi et al., 1999).

Estimates of the length of the maturation period range widely, from 2 months for the tropical A. affine (Band-Schmidt et al., 2003), 28-55 days for Tasmanian populations of A. catenella (Hallegraeff et al., 1998), 1-3 months for A. peruvianum (Figueroa et al., 2008a), and 12 months for $A$. tamarense from the St. Lawrence estuary (Castell Perez et al., 1998). When maturation is complete, cysts can germinate if permissive environmental conditions are met. Storage of cysts in the dark and at low temperature synchronized the germination of $A$. pseudogonyaulax cysts upon their re-exposure to the light (Montresor and Marino, 1996). The composition of the encystment medium can also modulate the length of maturation period in A. catenella; cysts produced in a diluted medium had a longer maturation period than those produced in N- or P-depleted conditions (Figueroa et al., 2005). Furthermore, maturation took longer when cysts were incubated in full strength medium versus in seawater. Above all, a considerable difference in maximum germination frequency and in germling viability has been detected among experiments carried out with different parental strains, further complicating the delineation of the factors that regulate life cycle transitions. These results call for comparative studies carried out using standardized experimental protocols with different strains for each species, and/or with populations from different geographic areas.

Information on excystment patterns and rates has been obtained from natural cyst assemblages stored under conditions comparable to those recorded in the field, and re-suspended in the light (and at times also in the dark) over a range of temperatures. The advantage of this approach is that cysts are produced under natural conditions and represent the integrated response to environmental factors. Cysts of $A$. tamarense collected in the Cape Cod area had a temperature window for germination between 5 and $21^{\circ} \mathrm{C}$ (Anderson and Rengefors, 2006). Natural cyst assemblages of the same species collected from Japanese coastal sediments and incubated at conditions matching those recorded in the field showed a clear seasonal pattern of germination, related to low temperature conditions $\left(10-15^{\circ} \mathrm{C}\right.$ ) in the bottom sediments (Itakura and Yamaguchi, 2001). A broad temperature window for germination $\left(2-16{ }^{\circ} \mathrm{C}\right)$ was described for $A$. tamarense cysts collected in the cold St. Lawrence estuary (Castell Perez et al., 1998). Excystment was not triggered by exposure to the light or by temperature shifts. The germination of cysts in natural sediments showed a marked seasonality with higher values ( $>50 \%$ ) from August to October. The results argued for either a temperature-controlled cyst maturation period, i.e., in colder waters the maturation period is longer, or an endogenous annual clock that controls the timing of germination. Evidence for the second mechanism had been provided for A. tamarense populations collected from the Gulf of Maine, where a clear seasonal pattern of cyst germination was detected under constant conditions and for multiple successive annual cycles (Anderson and Keafer, 1987).

Yet another variation of this mechanism was recently reported by Ni Rathaille and Raine (in press), who could not detect an endogenous annual clock in laboratory-stored $A$. minutum and $A$. tamarense cysts from Cork Harbor, Ireland. Instead they found seasonality in germination in cysts collected repeatedly from natural sediments. This suggests a type of secondary dormancy (found in higher plants), whereby cyst germination is seasonal, but the patterns of that regulation are determined by the external environment.

\subsection{Role of cysts in population dynamics}

A common assumption is that cyst "seedbeds" provide the inoculum for blooms of cyst-forming Alexandrium species. The concept of a discrete seedbed may not be appropriate in some locations, however, due to the widespread, dispersed distribution of some cysts and the likelihood that germination will occur over a large area. Nevertheless, there is evidence for localized cyst accumulations, both in estuarine systems and in deeper coastal waters, so perhaps these features are more common than previously expected. For example, cyst mapping within the Nauset Marsh System on Cape Cod revealed three highly localized seedbeds at the extreme ends of the complex network of channels and salt ponds that comprise that system (Crespo et al., in press). Not only are the cysts of $A$. fundyense found predominantly in three kettle holes or salt ponds, with virtually no cysts in between, but also detailed field surveys during bloom season documented the tight link between these cyst seedbeds and the areas of bloom initiation and retention within the system. A similar linkage between cyst accumulations in lagoons, harbors, or other such sites is found in the Mediterranean, and is responsible for localized blooms of $A$. catenella in Thau Lagoon (Genovesi et al., 2009) and Tarragona Harbor (Bravo et al., 2008). Examples of cyst seedbeds in deeper coastal waters are less common, perhaps due to the expense and difficulty of large-scale mapping, but some large studies have been conducted, revealing accumulations stretching hundreds of $\mathrm{km}$ along the shore, and $50 \mathrm{~km}$ or more offshore, such as those for A. fundyense in the Gulf of Maine (e.g., Anderson et al., 2005c).

In temperate regions, Alexandrium cysts remain quiescent during the winter months i.e., the cysts are mature and capable of germination, but are prevented from doing so by cold temperatures (Anderson, 1998; Anderson and Rengefors, 2006). As discussed above, a remarkable second level of germination control has been demonstrated for A. fundyense cysts and for which an 
internal, annual clock restricts germination to certain times of the year (Anderson and Keafer, 1987; Matrai et al., 2005). This endogenous annual clock drives the seasonality of $A$. fundyense blooms in deeper, coastal waters where environmental cues in bottom waters are weak.

Anoxia is yet another factor that regulates cyst germination, because cysts can germinate only in the presence of oxygen (Anderson et al., 1987). In bottom sediments, this tends to comprise only those cysts found at the very surface - perhaps the top few millimeters. The number of cysts that contribute to the bloom initiation process is therefore generally small relative to the total number in the sediments. This is in part because more cysts are often buried below the sediment surface than are present in the top, oxygenated layer (Anderson et al., 1982).

The size of the cyst germination inoculum from this surface layer may be small. For example, evidence is now emerging from germination flux experiments in Japanese embayments (Ishikawa et al., 2007) or in temperate salt ponds on Cape Cod (E. Vahtera, unpub. data) that germination rates are a fraction of a percent per day - meaning that $20 \%$ or less of the cysts in the top few millimeters of surface sediments might germinate in a 6-8 week season with a germination flux rate of only $\sim 0.4 \% \mathrm{~d}^{-1}$. With typical A. fundyense cyst concentrations in surface sediments in Cape Cod salt ponds (Crespo et al., in press), a week of germination would lead to an inoculum cell concentration of $\sim 70-100$ cells $L^{-1}$ at bloom initiation, roughly equivalent to what has been observed in the early stages of such blooms (Anderson et al., 1983; Crespo et al., in press). In subsequent weeks, the germination flux would be similar, but those cells would be greatly outnumbered by dividing cells in the water column. With an estimated inoculum of this size, the magnitude of the resulting bloom population appears to be regulated by factors affecting cell growth and retention, and not by the abundance of cysts in bottom sediments.

As is the case with localized salt ponds and embayments discussed above, examples of discrete cyst seedbeds that lead to large-scale regional blooms do exist. Quantitative cyst maps in deeper, open coastal waters are available for $A$. tamarense and $A$. fundyense (e.g., Anderson et al., 2005c), A. catenella (e.g., Yamaguchi et al., 1995), A. minutum (Erard-Le Denn et al., 1993) and $A$. ostenfeldii (MacKenzie et al., 1996). Cembella et al. (1988) argue that A. tamarense cysts along the northern shore of the St. Lawrence estuary initiate the toxic blooms which cause PSP on the south shore and further downstream in the estuary. On the northeast coast of Britain, A. tamarense cyst accumulations in the Firth of Forth have been linked to toxic blooms in the adjacent coastal waters to the north (Lewis et al., 1995). Evidence for the existence of a regional seedbed is also found in studies in the Gulf of Maine where a strong correlation between the abundance of $A$. fundyense cysts and the size of subsequent blooms (expressed as the extent of PSP toxicity closures along the coast) has been documented (McGillicuddy et al., 2011).

\subsection{Role of cysts in maintaining population genetic structure and functional diversity}

Cysts are long-lived and can be expected to contribute not only to initiation of planktonic populations in the next planktonic growth phase, but as well - although presumably to a lesser extent - to that in consecutive years. Patterns of excystment and subsequent survival and growth are therefore suggested to have considerable influence on the genetic structure of Alexandrium populations. According to a conceptual model, derived from microsatellite- and AFLP-based population genetic analyses, cyst seedbeds of Alexandrium harbor a similar population genetic structure and diversity to that found in planktonic populations (Alpermann et al., 2009). Interannual differentiation of planktonic populations as the result of clonal selection and shifts in genotype frequencies due to variations in selective constraints of the environmental regimes is the most likely explanation for observed population genetic substructures. Within a single year, environmental selection for differential growth and encystment can similarly act to establish and reinforce population structure. For example, an A. fundyense (Group I) bloom in the northeastern U.S. was shown to contain at least two genetically distinct subpopulations, comprising either early-bloom or late-bloom samples, whose succession is presumably influenced by environmental conditions (Erdner et al., 2011). These temporal differences in population composition are reinforced during the mating and encystment process, as the most probable matings will occur between genotypes from the same sub-population. The resulting cysts will be deposited at different times during the bloom but maintain the distinctive genetic signatures of their sub-populations, thereby maintaining the diversity of the overall regional cyst pool. The phenotypic adaptations of the progeny resulting from the germination of the resting cysts, may be the result of the exogenous environmental factors and the parental origin, as was first demonstrated by Figueroa et al. (2005) with A. catenella monoclonal cultures. With their diverse composition of descendants derived from successful growth of planktonic vegetative cells from different years, benthic cyst seedbeds constitute a genetic repository and may contribute substantially to the persistence of resident populations of Alexandrium by retaining a high degree of functional genetic diversity.

\section{Physiology and nutrition}

The traditional diatom bloom model cannot adequately describe Alexandrium blooms; as mentioned by Heisler et al. (2008), we need to "move away from simplistic inorganic nutrientdose-yield models". Although Alexandrium is an opportunistic genus relative to nutrition, simple relationships with classical nutrients should not be expected. Alexandrium has the ability to grow in both nutrient-rich (Townsend et al., 2005; Spatharis et al., 2007) in relatively pristine waters (Anderson et al., 2002), but also in waters where nutrient abatement has been carried out (e.g., Collos et al., 2009). It is difficult therefore to generalize about the nutrient-niche of Alexandrium, and the nutrient-dependent mechanisms that select for individual genera and among species that will bloom.

\subsection{Carbon}

Alexandrium species take up inorganic $C$ and produce oxygen like other autotrophs, but, as for other dinoflagellates, respiration (R) appears to be higher than in other phytoplankton classes, both relative to gross photosynthesis (PS) (Falkowski and Owens, 1978) and growth rate (Langdon, 1987). This is thought to be due to high energy requirements for maintenance of their large genome, with motility costs assumed to be negligible (Raven and Richardson, 1984). The compensation irradiance (when $\mathrm{PS}=\mathrm{R}$ ) for Alexandrium tamarense (=Gonyaulax tamarensis) was also found to be higher than for representatives of other phytoplankton classes (Falkowski and Owens, 1978). This tends to indicate that Alexandrium can be adapted to high irradiances (Smayda, 2008), although evidence to the contrary also exists (Chang and McClean, 1997). No photoinhibition of growth could be shown up to $800 \mu \mathrm{mol}$ photons $\mathrm{m}^{-2} \mathrm{~s}^{-1}$ for a Chilean strain of $A$. catenella (Carignan et al., 2002), but high sensitivity to UVB radiation was demonstrated.

Inorganic $C$ losses through respiration are probably important, but there is apparently very little excretion of organic C by Alexandrium (Chen and Wangersky, 1996; Flynn et al., 2008). Inorganic $\mathrm{C}$ fixation was found to be influenced by $\mathrm{N}$ uptake, either 
decreasing (Collos et al., 2004, 2007), or increasing (Leong et al., 2010) as $\mathrm{N}$ uptake increased, depending on the cell nutritional state. Uncoupling of $\mathrm{C}$ and $\mathrm{N}$ metabolism is also exemplified in cultures with large (2-4-fold depending on species and/or strains) increases in $\mathrm{C} / \mathrm{N}$ ratios following $\mathrm{N}$ exhaustion over time scales of 10-17 days (Flynn et al., 1996). Diel changes in C/N cellular ratios also occur in A. tamarense (MacIntyre et al., 1997) and A. catenella (Collos et al., 2006). In the former, the amplitude of such variations was higher under $\mathrm{N}$-deficiency (11-18 molC/molN) than under $\mathrm{N}$ sufficiency (7-10 $\mathrm{molC} / \mathrm{molN})$.

\subsection{Nitrogen}

Alexandrium growth rates on nitrate, ammonium and urea have been compared in many laboratory culture studies (e.g., Levasseur et al., 1995; Matsuda et al., 1999; Hamasaki et al., 2001; Dyhrman and Anderson, 2003). Generally, growth rates on ammonium are higher than on nitrate, but the differences are not always significant, except for one A. catenella strain (Dyhrman and Anderson, 2003). Urea is taken up by Alexandrium and typically supports growth in both laboratory cultures and in the field (Collos et al., 2007). Growth on urea may be lower than on either nitrate or ammonium, but again, the differences are not substantial, except for a strain of $A$. catenella (Matsuda et al., 1999) and one of A. fundyense (Levasseur et al., 1995), for which no growth was reported with urea as the sole $\mathrm{N}$-source. John and Flynn (1999) reported that amino-N from amino acids cannot support significant growth of $A$. fundyense. The differences in $\mathrm{N}$-dependent growth observed among strains must be tempered with the caveat that background $\mathrm{N}$ concentrations and sources were not always well controlled.

Early studies on $A$. tamarense showed that soil extract could increase growth relative to that on purely inorganic medium (Prakash, 1967). More detailed work confirmed the role of humic substances in enhancing growth in various media (Prakash and Rashid, 1968; Gagnon et al., 2005). In the latter study, humic additions significantly enhanced growth rates of $A$. tamarense relative to controls. Concentrations of these humic substances remained constant throughout exponential growth phase, suggesting that they were acting mainly as growth promoters. Carlsson et al. (1998) reported an increase in A. catenella growth rate on nitratebased medium when humic substances of terrestrial origin were added. Doblin et al. (2001) showed that humic substances in equimolar concentrations could replace nitrate as an $\mathrm{N}$ source and support similar growth rates of the same species.

Riverine dissolved organic nitrogen (DON; $>1 \mathrm{kDa}$ ) did not yield significant differences between various ratios of $\mathrm{NO}_{3} / \mathrm{DON}$ on growth of $A$. tamarense in $\mathrm{f} / 2$ medium, although chlorophyll content decreased as riverine DON increased (Stolte et al., 2002). In contrast, Fagerberg et al. (2009) reported that $A$. minutum could benefit from riverine high molecular weight (10-100 kDa) DON. Similarly, DON from marine diatom blooms significantly increased (by 34\%) the growth rate of $A$. catenella in cultures (Loureiro et al., 2009) relative to growth on nitrate only. Ammonium was not responsible for the increased growth, implying that DON was used directly.

Nitrogen uptake kinetics of Alexandrium species are not very different from those of other phytoplankton (Kudela et al., 2010), with the possible exception of linear kinetics, (i.e., no substrate saturation) for urea uptake (Jauzein et al., 2008a), N-loss exemplified by release of nitrite during nitrate assimilation (Flynn and Flynn, 1998) and release of ammonium during urea assimilation (Jauzein et al., 2008a). Multiphasic kinetics allow Alexandrium species to exploit patches of elevated nutrient concentrations, but they are also competitive at scavenging low $\mathrm{N}$ levels (e.g., Collos et al., 2007). In some cases, substrate inhibition of uptake occurs for ammonium at concentrations of $100 \mu \mathrm{M}$ (Leong et al., 2010).
There are also large intra-specific differences in uptake and assimilation kinetics (Collos et al., 2006; Jauzein et al., 2008a). Furthermore, for a given strain, changes in kinetic parameters, such as the half-saturation constant $\left(K_{\mathrm{s}}\right)$ and maximum uptake rate $\left(V_{\max }\right)$ occur over the course of a day for both ammonium and urea, in relation with the daily irradiance change (Jauzein et al., 2008a). In natural populations of $A$. catenella, $K_{\mathrm{s}}$ for ammonium can change by an order of magnitude over a time scale of a few days (Collos et al., 2007).

Dark uptake has been observed in Alexandrium but mostly for ammonium and urea, with very little nitrate uptake occurring in the dark (Maclsaac et al., 1979), or most nitrate being released as nitrite (Flynn and Flynn, 1998). The dark/light uptake ratios were related to the oxidation state of the N-source (Leong et al., 2010).

The nitrate uptake systems of $A$. catenella and A. minutum were shown to be very sensitive to inhibition by ammonium (Collos et al., 2004; Maguer et al., 2007). Ammonium was also found to inhibit the urea uptake system of $A$. catenella, but this phenomenon seemed to be strongly strain-dependent. Whereas strains from Thau lagoon on the French Mediterranean coast were very sensitive, strains from the Spanish Mediterranean coast were much less so, indicating a possible geographical difference linked to different nutrient regimes (Jauzein et al., 2008b).

Alexandrium cells accumulate ammonium internally but there are large inter-specific (Thoresen et al., 1982; Flynn and Flynn, 1998) as well as intra-specific (Collos et al., 2006) differences. In some cases, internal ammonium can represent up to $30 \%$ of the total cell $\mathrm{N}$ of $A$. catenella strain TL01 (Collos et al., 2006), a high value for phytoplankton but average for dinoflagellates; this was related to high uptake rates. Compared to other dinoflagellates, the $\mathrm{N}$ physiology of Alexandrium species is characterized by abnormally high internal levels of glutamine and arginine, as possible precursors of PSP toxins (e.g., Anderson et al., 1990).

\subsection{Phosphorus}

Although in most instances inorganic $\mathrm{P}$ is considered to be the primary P-nutrient for natural Alexandrium bloom populations, organic $\mathrm{P}$ compounds such as adenosine triphosphate or guanosine diphosphate can increase the growth rate of some Alexandrium species significantly (Matsuda et al., 1999). Glycerophosphate is also sometimes used as a better P-source than inorganic phosphate in culture medium (Prakash, 1967; Achiha and Iwasaki, 1990; but see Matsuda et al., 1999). Low molecular weight organic-P, such as phosphomonoesters, is apparently hydrolyzed to inorganic phosphate before being used for growth (Gagnon et al., 2005).

Inorganic P uptake for Alexandrium has been characterized in a few studies (Cembella et al., 1984; Yamamoto and Tarutani, 1999; Ou et al., 2008). Half-saturation constants range from 0.01 to $2.6 \mu \mathrm{M}$, and were related to growth rate in A. catenella (Jauzein et al., 2010). No multiphasic kinetics have been reported, but the range of concentrations tested so far is also limited. Alexandrium appears to be a "storage specialist" in that it can use phosphate pulses for luxury consumption and storage for future use during periods of $\mathrm{P}$ depletion (Yamamoto and Tarutani, 1999; Labry et al., 2008).

\subsection{Trace metals and vitamins}

Early studies reported high iron (Fe) requirements for Alexandrium (Anderson and Morel, 1979; Doucette et al., 1989). Very recently, He et al. (2010) studied the effect of Fe limitation on A. tamarense. Growth rate and chlorophyll $a$ content were reduced by half, and protein by a factor of three in Fe-limited cells ( $1 \mathrm{nM} \mathrm{Fe}$ ) relative to Fe-replete controls ( $1 \mu \mathrm{M} \mathrm{Fe})$.

Siu et al. (1997) studied in detail the metal requirements for $A$. catenella. The optimal ranges found for cobalt, copper, iron, 
manganese, molybdenum, selenium and zinc do not deviate significantly from the composition of commonly used culture media, with the possible exception of selenium. The latter was found to be required in the range $20-100 \mathrm{nM}$, whereas, the concentration recommended in recent artificial seawater (e.g., ESAW) recipes is only $1 \mathrm{nM}$ and $10 \mathrm{nM}$ in $\mathrm{K}$ and L1 media supplements to natural seawater (Andersen et al., 2005). Both selenium and nickel are now often added for growing Alexandrium species, e.g., for growth of $A$. fundyense in $\mathrm{f} / 2$ medium with urea as N-source (TaroncherOldenburg et al., 1997). In contrast, other metals such as copper are sometimes reduced to grow Alexandrium (Taroncher-Oldenburg et al., 1997), relative to concentrations given for $\mathrm{f} / 2$ medium.

Vitamin requirements of $A$. catenella from Hong Kong waters (Siu et al., 1997 do not deviate from those of other phytoplankton. This contrasts with a strain of $A$. catenella from the South China Sea and of A. minutum from Rio de Vigo (Spain), which required cyanocobalamine only, but neither biotin nor thiamine (Tang et al., 2010).

\subsection{Mixotrophy}

In one of the earliest studies on toxin production in Alexandrium, Proctor et al. (1975) reported uptake of fourteen ${ }^{14} \mathrm{C}$-labeled organic compounds by $A$. catenella, the most prominently retained in cells being guanine, guanosine, formate and urea. For Alexandrium species, there is evidence for uptake of large molecules such as dextran-labeled with fluorescent markers (Legrand and Carlsson, 1998), and humic substances labeled with ${ }^{14} \mathrm{C}$ (Doblin et al., 2001). Those humic substances are thought to play a role as growth promoters (by complexing metals or affecting nutrient transport mechanisms) rather than sources of nutrients (Gagnon et al., 2005).

Urea assimilation by Alexandrium involves the enzyme urease (Dyhrman and Anderson, 2003). Urease activity was highest in Nstarved and urea-grown cultures, and undetectable in nitrategrown cultures. Indirect evidence from mass balance considerations indicates use of DON other than urea both in laboratory cultures (Collos et al., 2004, 2006) and natural populations of $A$. catenella (Collos et al., 2007).

Under P deficient conditions, some Alexandrium species are known to produce alkaline phosphatase (Oh et al., 2002; Ou et al., 2006) allowing use of organic P. Although Flynn et al. (1996) could not establish alkaline phosphatase activity as an indicator of phosphate stress in three Alexandrium species, Oh et al. (2002) and Jauzein et al. (2010) reported synthesis of this enzyme below an inorganic $\mathrm{P}$ threshold of $0.4-1 \mu \mathrm{M}$ in A. tamarense and A. catenella.

\subsection{Phagotrophy}

Phagotrophy is apparently widespread among Alexandrium species (Jeong et al., 2010). Both bacteria and flagellates have been observed in food vacuoles of Alexandrium (Jeong et al., 2004). A. ostenfeldii is also known as a mixotroph with phagotrophic capabilities, based on examination of food vacuoles (Jacobson and Anderson, 1996). In a recent review of the phagotrophic capacities of mixotrophic dinoflagellates (Jeong et al., 2010), A. minutum was reported to ingest cyanobacteria, and $A$. catenella both heterotrophic bacteria and cyanobacteria, but $A$. tamarense could also ingest other prey such as haptophytes, cryptophytes, small diatoms, the raphidophyte Heterosigma akashiwo and the dinoflagellates Amphidinium carterae and Prorocentrum minimum.

\subsection{Heterogeneity in gross (or intrinsic) growth rates}

Alexandrium species will grow in a variety of media, based either on natural seawater enrichments (e.g., f/2, K, L1) or artificial (e.g., AK, Aquil, ESAW) seawater. Genetic variability in growth rate is extensive among Alexandrium species and strains even when grown under standard conditions. Alexandrium tamarense, for example, can exhibit a range of growth rates $(\mu)$ of up to $1.0 \mathrm{~d}^{-1}$. Brand (1981) recorded a high range of $\mu$ from 0.19 to $0.66 \mathrm{~d}^{-1}$ for 75 clones of $A$. tamarense grown under identical conditions, whereas Costas (1990) found a larger and Tillmann et al. (2009) a lower clonal variation in $\mu$. It may be significant that the highest $\mu$ ever recorded for this species was for a culture incubated under natural irradiance and temperature (Smayda, 1996).

For $A$. catenella, the highest $\mu$ recorded in laboratory cultures was $0.55 \mathrm{~d}^{-1}$ (Matsuda et al., 1999; Collos et al., 2004), still lower than the highest gross $\mu\left(0.89 \mathrm{~d}^{-1}\right)$ recorded for monospecific blooms of the same species by the dilution method (Collos et al., 2007). These discrepancies seem to point out possible inadequacies of culture media and/or culture conditions relative to the natural environment, and the consequent possible underestimation of growth rate of Alexandrium species under laboratory conditions. This is important regarding, for example, the wide and long-standing debate on the relative growth rates of diatoms and dinoflagellates, and determination of realistic rates for parameterization of predictive bloom models.

\section{Toxins and allelochemical interactions}

The genus Alexandrium is notorious for the production of potent neurotoxins and other unrelated allelochemicals affecting species interactions and the health of marine fauna, as well as of human seafood consumers via paralytic shellfish poisoning (PSP). Alexandrium has the distinction of being the first dinoflagellate genus associated unequivocally as the source of phycotoxins affecting human health. Investigations on the cause of toxicity in shellfish established a link between $A$. catenella (referred to as Gonyaulax catenella) in the water column and shellfish toxicity at the Pacific coast and for A. tamarense (referred to as Gonyaulax tamarensis) at the Atlantic coast of North America (reviewed by Prakash et al., 1971). The key neurotoxic tetrahydropurine alkaloid saxitoxin (STX) was isolated and characterized from cultures of $A$. catenella (Schantz et al., 1966). The advent of liquid chromatography coupled to tandem mass spectrometry, in concert with high resolution NMR, for structural elucidation has led to the characterization of more than a dozen naturally occurring PSP toxin analogues among various Alexandrium species.

Although Alexandrium is not the unique source of PSP toxins among dinoflagellates - these toxins are also produced by Gymnodinium catenatum and Pyrodinium bahamense, as well as several genera of predominantly freshwater cyanobacteria - the wide distribution of this genus renders it the most globally important producer. In this review the multifaceted aspects related to toxigenicity of Alexandrium are restricted to a focus on highlights of three major issues: (1) the validity of toxin composition profiles as chemotaxonomic and phenotypic markers within and among Alexandrium species; (2) biosynthesis of saxitoxin and analogues and spirolides; and (3) allelochemical interactions between and among species.

\subsection{Variation in toxin content and composition}

In Alexandrium, the composition of PSP toxins typically includes several members of one or more of the following sub-groups: (1) carbamoyl toxins, including saxitoxin (STX), neosaxitoxin (NEO) and the C-11 O-sulfated analogues gonyautoxins (GTX1-GTX4) and (2) $\mathrm{N}-21$ sulfocarbamoyl analogues (B1 = GTX5, B2 = GTX6, C1-C4). Alexandrium strains produce different relative amounts of these derivatives, but the composition is a stable phenotypic trait and significant shifts tend to occur only under rather extreme change in 
growth regime in batch and semi-continuous cultures (e.g., Hall, 1982; Boyer et al., 1987; Boczar et al., 1988; Anderson et al., 1990).

The production of a certain suite of toxins seems to be fixed genetically for each clonal strain of Alexandrium (Anderson et al., 1990; Cembella, 1998 and references therein). Although the PSP toxin profile varies widely within and among Alexandrium species, general characteristics can usually serve to identify the distinction from the toxin composition of other dinoflagellate genera (Pyrodinium and Gymnodinium) and cyanobacteria, or as sequestered in shellfish. For example, in Alexandrium species, decarbamoyl derivatives (dcSTX, dcNEO, dcGTX1-4) and the N-21 sulfocarbamoyl analogues C3, C4 are rarely found. Within Alexandrium, it is sometimes but not always possible to identify species-specific toxin markers. Members of the A. minutum group (including also A. ibericum, A. lusitanicum, A. angustitabulatum) tend to produce primarily or exclusively gonyautoxins (GTX1-GTX4) (Cembella et al., 1987). Among species of the A. tamarense complex, however, toxin profiles are too diverse to be diagnostic for species discrimination.

Cellular toxin content is a less stable phenotypic character of a clonal isolate of Alexandrium than its toxin profile (Cembella et al., 1987). Average cellular toxin content of toxigenic Alexandrium isolates varies considerably (up to an order of magnitude) among different growth phases and environmental regimes in batch cultures, with maxima usually found in exponential phase and under P-limitation (e.g., Boczar et al., 1988; Anderson et al., 1990). Furthermore, within Alexandrium species, clone-specific toxin content can vary from undetectable to $>100 \mathrm{fmol} \mathrm{cell}^{-1}$, even among clones isolated from the same geographical population. This implies that cell PSP toxin content is not reliable as a species-, ribotype-, or population-characteristic and must be interpreted cautiously. Even though distributions of toxin phenotypes of $A$. minutum appeared not to overlap in Irish coastal waters, with toxic forms found in the south, and non-toxic strains in the west (Touzet et al., 2008a,b), toxic and non-toxic strains of A. minutum cluster together in phylogenetic analyses (Lilly et al., 2005). On the other hand, both toxic and non-toxic phenotypes, corresponding to the Group I and Group III clades within the A. tamarense complex (Lilly et al., 2007) have been documented to co-occur geographically in the Shetland Islands in Scotland (Touzet et al., 2010) and Belfast Lough in Northern Ireland (Brosnahan et al., 2010).

Investigations on PSP toxin composition of Alexandrium isolates and natural population have interpreted toxin profiles chemotaxonomically to differentiate among morphotypic and genotypic variants within and among species and geographical populations (Cembella et al., 1987; Anderson et al., 1994). These early studies revealed considerable inter-population variation in toxin composition not only between different locations, but also among isolates within geographical populations, although biogeographical trends could often be discerned. In the Gulf of Maine, the apparent northward gradient of increasing cell toxicity was attributed to differences in total cellular toxin content, as well as to a progressive shift in relative composition to more highly toxic carbamoyl derivatives (Anderson et al., 1994). Multivariate statistical techniques applied to toxin composition data from regionally separated populations showed that in some cases regional populations of Alexandrium can clearly be distinguished from others by toxin profiles (Cembella et al., 1987; Anderson et al., 1994; Cembella and Destombe, 1996). Comparison of PSP toxin composition of field samples of planktonic A. tamarense populations from different sampling sites in eastern Canada (Cembella and Destombe, 1996) serves to illustrate biogeographical patterns. Populations from the Bay of Fundy and the St. Lawrence estuary display homogeneity in the relative amounts of PSP toxins, whereas populations from Nova Scotia were characterized by larger intra-regional differences in toxin composition. Based upon toxin profiles as a chemotaxonomic character at the population level, this implies that the St. Lawrence populations are well mixed and presumably seeded from the same cyst beds at the northern shore of the estuary. Yet they are clearly distinct from the other eastern populations from Nova Scotia, indicating a geographical separation that leads to reproductive isolation of populations.

There are two possible explanations for the development of inter-population differences in PSP toxin composition among $A$. tamarense/fundyense (Group I ribotype) populations at the Atlantic coast of North America (Anderson et al., 1994). One explanation is that environmental factors favor the selection of certain phenotypically differentiated individuals originating from a common cyst bed. Such locally differing selection during development of vegetative growing populations could lead to the establishment of phenotypically differentiated bloom populations after dispersal to different regions. Alternatively, dispersal of Alexandrium populations from different centers of origin may explain inter-population differences in the relative composition of PSP toxins. Whereas the first mechanism is based on the idea of short-term differentiation of planktonic populations, the second implies long-term processes, which might be enhanced by prevailing current patterns.

These two hypotheses were tested using microsatellite analyses of temporally and geographically separated samples from a widespread $A$. fundyense bloom in the Gulf of Maine (Erdner et al., 2011). Results indicate that Alexandrium blooms derive from a single regional population of $A$. fundyense comprising at least two genetically distinct sub-populations. These subpopulations were characteristic of early- and late-bloom samples and were collected from the northern and southern areas of the bloom, respectively. The presence of genotypes from both sub-populations in midbloom samples from north of Cape Cod, combined with drifter data on current patterns, does not support the presence of separate north and south centers of origin for the bloom. Although the definitive test of these two alternatives - determination of the genetic composition of the cyst seedbeds - remains to be done, it is most likely that Alexandrium blooms in this region originate from a common cyst source, congruent with the former hypothesis of Anderson et al. (1994) and the conceptual model proposed by Alpermann et al. (2009).

Distribution of toxin phenotypes of $A$. ostenfeldii, which may produce spirolides and/or PSP toxins, may be interpreted similarly, but available data are more limited than for the A. tamarense complex (Cembella and Krock, 2007). Nevertheless, stability of the spirolide toxin profiles indicates that they may also serve as phenotypic or chemotaxonomic markers. Strains of $A$. ostenfeldii from New Zealand and the Baltic Sea tend to produce exclusively PSP toxins, whereas those from Nova Scotia yield only spirolides, and some from Denmark can synthesize both toxin groups. The spirolide profiles of both isolates and field populations from the northwestern Atlantic are often heavily dominated by 13desmethyl spirolide $C$ (13-desmeC), but may also contain variants such as spirolide A, B, C or D-type (Cembella et al., 2000, 2001). In contrast, an isolate from the North Sea coast of Scotland yields exclusively 20-methyl spirolide G (20-meG), whereas one from the Celtic Sea contains this analogue, but also slight amounts of 13desmeC. Multi-year samples of field populations containing $A$. ostenfeldii from the North Sea and adjacent waters consistently showed 20-meG as dominant, albeit that 13-desmeC was also often present, particularly along the Irish coast. In comparison, Mediterranean isolates contain overwhelmingly 13-desmeC. Analysis of spirolide toxin profiles from natural populations and isolates of $A$. ostenfeldii from the Gulf of Maine revealed not only the regional diversity among populations but also the presence of five distinct spirolide toxin phenotypes among isolates (Gribble et al., 2005). 
These examples illustrate that biosynthesis of particular toxin analogues is subject to inter- and intraspecific variation, including at the population level and even in some cases among clones within a population. In any case, the interpretation of cell toxin content and composition as phenotypic markers in natural populations of Alexandrium or from clonal isolates is subject to major limitations and pre-conditions that are not usually fulfilled in most studies. First, determination of cell toxin content and composition from mixed assemblages can include several Alexandrium taxa that may not be resolved morphologically or genetically. Second, in multiclonal populations the cell toxin content and profile can only represent the mean of the relative distribution of toxin phenotypes. Finally, often only one or a few clonal isolates are selected to represent the population without reference to genetic heterogeneity. This invokes the "genetics of survivors" and autecological dependency limitations for population studies. In one of the rare studies comparing PSP toxin variation with genetic markers for a high number of cultured isolates (88 clones), Alpermann et al. (2010) addressed this issue and showed that within a geographical population of $A$. tamarense (Group I/North American ribotype) from the North Sea, PSP toxin composition was highly heterogeneous among clones. Nevertheless, cluster analysis did reveal hierarchical grouping according to toxin profiles, but no clear linkage to molecular markers such as AFLP and microsatellites. Similar findings were obtained for $A$. fundyense populations from the Gulf of Maine (D.M. Anderson, unpub. data).

\subsection{Toxin biosynthesis}

The biosynthesis and gene regulation of the tetrahydropurine saxitoxin and analogues in dinoflagellates, and particularly among Alexandrium species, has long been the subject of intensive speculation and research interest. Based upon stable isotope precursor labeling experiments followed by NMR for both the cyanobacterium Aphanizomenon flos-aquae and A. tamarense, Shimizu (1996) proposed a unique biosynthetic pathway for saxitoxin (STX) involving arginine, acetate, and methionine as building blocks, with assembly initiated by a Claisen condensation between arginine and acetate. Characterization of putative PSP toxin biotransformation enzymes (e.g., N-sulfotransferases) from A. catenella and Gymnodinium catenatum (Ishida et al., 1998) also tended to support the proposed biosynthetic pathway for both dinoflagellates and cyanobacteria. The fact that PSP toxin profiles in Alexandrium exhibit a biparental inheritance pattern that is consistent with Mendelian segregation implies that expression of a specific toxin profile is regulated by nuclear genes (Sako et al., 1992).

Nevertheless, until recently the nature of the saxitoxin biosynthetic genes in Alexandrium has remained elusive. As is the case with most large-celled free-living dinoflagellates, Alexandrium has a huge nuclear genome ( $>200$ pg DNA), comprising a high number (up to about 150) of chromosomes with permanently condensed chromatin, and lacking canonical histones, but rich in modified nucleotides, and with a high $\mathrm{G}-\mathrm{C}$ base pair ratio. These factors, in addition to the complexity of genes organized as tandem repeats or with multiple introns, and transcribed by a spliced-leader trans-splicing mechanism (Lin et al., 2010), have to date confounded the sequencing of the Alexandrium genome. An early study of $A$. fundyense based upon differential display of genes (Taroncher-Oldenburg and Anderson, 2000) following cell synchronization identified three genes, Sadenosylhomocysteine hydrolase, methionine aminopeptidase, and a histone-like protein, possibly related to PSP toxin production. More recent analysis of expressed sequence tags (ESTs), short subsequences transcribed from cDNA libraries, for $A$. fundyense
(Hackett et al., 2005), A. ostenfeldii (Jaeckisch et al., 2008), and A. minutum (Yang et al., 2010) has facilitated the search for toxin biosynthetic genes. An EST library constructed for the dinoflagellate A. minutum (Yang et al., 2010), combined with the application of an oligonucleotide microarray uncovered 192 differentially expressed genes between toxic and non-toxic strains. Although candidate genes for possible involvement in growth regulation and/or toxin biosynthesis were found, there were no confirmed hits for the PSP toxin biosynthetic genes as in cyanobacteria.

In contrast to the biosynthesis of PSP toxins in synchronized $A$. fundyense cells, which occurs in G1 phase of the cell cycle following a light-dependent transition (Taroncher-Oldenburg et al., 1997; Taroncher-Oldenburg and Anderson, 2000), spirolide biosynthesis in A. ostenfeldii is restricted primarily to the G2 phase (John et al., 2001). Stable isotope feeding experiments with $A$. ostenfeldii followed by NMR (MacKinnon et al., 2006) confirmed the biosynthesis of spirolide 13-desmethyl $\mathrm{C}$ as a polyketide derived from acetate units, with the imine moiety derived intact from glycine. Comparative and functional genomic analysis of an EST library of $A$. ostenfeldii (Jaeckisch et al., 2008) was successful in identifying a range of polyketide synthase (PKS) genes with high sequence conservation in respect to other dinoflagellates producing polyketide toxins, such as Karenia brevis (Monroe and Van Dolah, 2008). Specific association of particular PKS genes with spirolide biosynthesis has not yet been confirmed.

The discovery of a saxitoxin gene cluster (sxt) and a biochemically determined plausible biosynthetic pathway for saxitoxin in the cyanobacterium Cylindrospermopsis raciborskii (Kellmann et al., 2008), and variations of the sxt cluster to account for the biosynthesis of sulfated analogues (GTXs) in other cyanobacteria (Soto-Liebe et al., 2010) dramatically accelerated the search for homologous gene clusters in Alexandrium. Mass sequencing of mRNA transcripts from saxitoxin-producing strains of Alexandrium and several other STX-producing dinoflagellates, coupled with in silico transcriptome analyses and various PCR techniques, successfully identified such STX-synthesis genes (Stüken et al., 2011; Hackett et al., in press). Hackett et al. (in press) identified 265 putative homologs of 14 cyanobacterial STX synthesis genes, including all of the genes directly involved in toxin synthesis in cyanobacteria (Kellmann et al., 2008). The Alexandrium transcripts of the sxtA gene have the same domain structure as those from cyanobacterial homologs, but the dinoflagellate transcripts are monocistronic, occur in multiple copies, and contain typical dinoflagellate spliced-leader sequences. Furthermore, investigation of STX-producing and non-producing dinoflagellate strains from six different genera showed congruence for the presence of the sxtA gene and STX-synthesis, except for three strains of $A$. tamarense, for which sxtA was amplified without evidence of STX or derivatives (Stüken et al., 2011).

In spite of the fact that the basic pathway for STX biosynthesis is generally consistent with that proposed originally by Shimizu (1996) for both cyanobacteria and dinoflagellates, molecular evidence now suggests that the functional homologs of $s x t A, s x t G$ and $s x t B$ arose independently in dinoflagellates and cyanobacteria (Hackett et al., in press; Stüken et al., 2011).

\subsection{Allelochemical interactions}

Allelochemical activity towards potential protistan and macrozooplankton grazers and/or resource competitors has been widely documented among Alexandrium species. Against other protists, allelochemical effects of exposure to Alexandrium cells or cell-free culture medium (filtrate) of Alexandrium spp. typically results in immobilization of target cells followed by their lysis or cyst formation (Tillmann and John, 2002; Fistarol et al., 2004). Addition of filtered culture medium of an allelopathic strain of $A$. tamarense 
to a natural plankton assemblage provoked drastic alterations in the experimental plankton community and especially a marked reduction of ciliate micrograzers. Protists shown to be sensitive to Alexandrium allelochemical activity include various diatoms, haptophytes, cryptophytes, chlorophytes, ciliates and even other dinoflagellates; the latter group includes both obligate autotrophic and heterotrophic as well as mixotrophic species (e.g., Hansen, 1989; Arzul et al., 1999; Tillmann and John, 2002; Tillmann et al., 2007). The potency and wide spectrum of putative targets suggests that allelochemical interactions may be highly adaptive and play an important role in Alexandrium bloom dynamics and ecological niche differentiation. However, allelopathic activity is not ubiquitous among Alexandrium populations or universally effective against all potential targets in natural plankton assemblages; even in extremely dense Alexandrium blooms grazing by tintinnid ciliates can contribute to bloom termination (Sorokin et al., 1996).

Neither the chemical nature of the allelochemicals nor their genetic regulation and mode of action are well understood for Alexandrium species. Given the frequent occurrence of saxitoxin and analogues among Alexandrium populations, it has long been postulated and even assumed that these potent sodium-channel blocking neurotoxins act ecologically as a classic chemical defense against grazers and competitors (reviewed by Cembella, 2003) in the "watery arms race" sensu Smetacek (2001). This interpretation is now considered overly simplistic or perhaps even generally inaccurate for Alexandrium.

Studies of various copepod species grazing upon Alexandrium species and isolates differing in PSP toxin content and composition have yielded widely diverging responses. The differential responses among copepods range from loss of swimming coordination and physiological incapacitation through toxindependent differential grazing, chemically mediated avoidance and post-ingestion rejection behavior, to no apparent relationship between cellular composition of PSP toxins and grazing behavior, grazer mortality or fecundity (reviewed by Turner et al., 1998). Thus the presence of a universal defense mechanism against copepods linked directly to PSP toxin content or composition of Alexandrium cells appears not to be sustainable.

Lytic allelochemical activity of selected strains of Alexandrium spp. towards a wide variety of both photoautotrophic and heterotrophic protists was apparently unrelated to the cellular PSP toxin content (Tillmann and John, 2002). Further experiments with multiple clones of $A$. tamarense from the Scottish east (Tillmann et al., 2009) showed high clonal heterogeneity in lytic potency against the cryptophyte Rhodomonas salina and the heterotrophic dinoflagellate predator Oxyrrhis marina, but without obvious association to cellular PSP toxin content or composition. These results indicate that PSP toxins are not the primary allelochemical in Alexandrium and may not be crucial in determining outcomes of competitive or grazing interactions among protists in natural assemblages.

In the first experiments on grazing interactions of $A$. ostenfeldii and the tintinnid Favella ehrenbergii the presence of PSP toxins (albeit as very low cellular levels) was proposed as possible waterborne cues to account for the threshold-dependent retrograde swimming behavior and grazing inhibition of the tintinnid (Hansen et al., 1992). Yet other experiments with this tintinnid exposed to multiple clones of $A$. tamarense (Hansen, 1989) that varied widely in PSP toxin content failed to show a relationship of these toxins to tintinnid growth or behavior. The later discovery of spirolides in the isolates of $A$. ostenfeldii used in the tintinnid experiments (Hansen, 1989; Cembella et al., 2000, 2001) suggested that spirolides were acting as allelochemicals. This possible linkage was disproved, however, in experiments with $A$. ostenfeldii strains exposed to a wide variety of heterotrophic and phototrophic protists, which showed that lytic activity was independent of spirolide content (Tillmann et al., 2007).

The potent immobilization and lytic activity of Alexandrium allelochemicals against protistan cells appears to target external cell membranes (Ma et al., 2009). Furthermore, it is now clear that this activity is not mediated primarily (if at all) by known low molecular weight phycotoxins. In fact, it appears likely that a complex of allelochemicals, as originally suggested by Arzul et al. (1999) and/or high molecular weight (perhaps macromolecular) components may be involved. Most recent evidence indicates that lytic compounds from $A$. tamarense increase permeability of the cell membrane for $\mathrm{Ca}^{2+}$ ions, but do not specifically bind to these ion channels or cause non-specific lysis of target membranes by detergent-like activity (Ma et al., 2011). Furthermore, although the molecular targets of the lytic compounds are likely to involve sterol components of membranes, the high molecular weight (between $7 \mathrm{kDa}$ and $15 \mathrm{kDa}$ ) precludes a direct analogy to the mode of action of karlotoxins.

Other allelochemicals of the genus Alexandrium include a heatlabile exotoxin from A. minutum (Lush et al., 2001) with potent toxicity towards the brine shrimp Artemia salina. A hemolytic exotoxin with a molecular weight $>10 \mathrm{kDa}$ and described as proteinaceous has been isolated from A. taylori (Emura et al., 2004), and a novel high molecular weight (about $1000 \mathrm{kDa}$ ) hemolytic and cytotoxic compound, most likely polysaccharide-based, was reported from $A$. tamarense (Yamasaki et al., 2008). Nevertheless, different chemical and physical properties and the apparent lack of either polysaccharide or proteinaceous components in the structure of the lytic allelochemicals from $A$. tamarense that are effective against other protists suggest that these compounds are not related.

Allelochemicals may be produced by Alexandrium as effectors of other species, or transduced by Alexandrium cells to elicit targeted behavioral and gene expression responses. In the latter case, $A$. tamarense cell chains were shown to reduce encounter rates with grazers by splitting into single cells or shorter chains and slowing down swimming speed when exposed to waterborne copepod cues (Selander et al., 2011). Naturally occurring concentrations of copepods may provoke a $>25$-fold increase in cell PSP toxin content in A. minutum, which has also been shown to correlate with increased resistance to copepod grazing (Selander et al., 2006). Waterborne cues of copepods induce change in both cell PSP toxin content and gene expression profiles in Alexandrium spp. (e.g., Wohlrab et al., 2010; Yang et al., 2011). In a transcriptomic model study of copepod-induced shift-up in cell PSP toxin content in A. minutum based upon a DNA microarray (Yang et al., 2011), a limited set of 14 genes were differentially regulated by exposure to water borne cues from copepods. Exposure of $A$. tamarense to three copepod species (Calanus helgolandicus, Acartia clausii, and Oithona similis) and their corresponding waterborne cues also substantiated the potential for a rapid increase in PSP toxin content in the dinoflagellate (Wohlrab et al., 2010). This functional genomic approach indicated that regulation of serine/threonine kinase signaling pathways has a major influence in directing the copepodcues into different intracellular cascades and networks in $A$. tamarense. Bidirectional allelochemical interactions provide a plausible basis for co-evolutionary mechanisms between Alexandrium and its predators and competitors in natural bloom populations.

\section{Bloom dynamics}

\subsection{General mechanisms}

The complexities of Alexandrium blooms in dynamic coastal or estuarine systems are far from understood. One common 
characteristic of such blooms is that the coupling between physics and biological "behavior" such as swimming, vertical migration, or physiological adaptation holds the key for understanding these phenomena, yet this is perhaps where our knowledge of this genus is weakest.

Once vegetative cells enter the water column following cyst germination, their net growth and transport are heavily affected by circulation, nutrients, stratification, and other chemical or physical factors (see also biological loss terms below). Although many of these interactions remain uncharacterized, blooms of several Alexandrium species have been linked to particular water masses. There are many examples of the importance of fronts in HAB bloom dynamics. For example, patterns of PSP toxicity and A. tamarense cell distributions in the lower St. Lawrence estuary have been linked to the plume produced by the Manicouagan and AuxOutardes rivers (Therriault et al., 1985). The trans-estuarine freshwater plume generates a highly stratified water column that favors proliferation and retention of vertically migrating Alexandrium. The frontal system generated by the Manicouagan and AuxOutardes plume serves as an initiation zone and the Gaspé current as a transport pathway along the south shore. The physical system is not the entire story, however. Although the riverine plume is essential for $A$. tamarense, this species is most abundant during mid- to late-summer, even though the characteristics of the plume and the front are well-established for a much longer interval. Clearly, other factors are regulating $A$. tamarense dynamics. Therriault et al. (1985) suggested that $A$. tamarense blooms in the St. Lawrence develop only when the proper combination of meteorological and hydrodynamic factors coincide to produce high surface water temperatures, maximum water column stability, low nutrients, and low winds. These dynamics have been explored in a bloom modeling study of the region by Fauchot et al. (2008).

Another example of the importance of physical forcings in Alexandrium bloom dynamics is in the Gulf of Maine, where the temporal and spatial pattern of persistent PSP outbreaks have been linked to a large-scale coastal current system that traverses the Gulf (Franks and Anderson, 1992; Anderson et al., 2005a,d). Conceptual models of $A$. fundyense bloom dynamics (Anderson et al., 2005c; McGillicuddy et al., 2005) include key features such as two large cyst "seedbeds" - one in the Bay of Fundy and the other offshore of mid-coast Maine. Cysts germinate from the Bay of Fundy seedbed, causing recurrent coastal blooms in the bay that are self-seeding with respect to future outbreaks in that area. The blooms also contribute to populations in the eastern section of the Gulf as some cells escape the Bay of Fundy and enter the eastern segment of the Maine coastal current (EMCC) where they form blooms. Some Alexandrium cells travel south and west with that current, while others are deposited as cysts in the mid-coast Maine seedbed. In subsequent years, these latter cysts (combined with cells from the EMCC) inoculate blooms that cause toxicity in western portions of the Gulf and possibly offshore waters as well.

Another important unknown in the coastal blooms concerns the possible stimulation of Alexandrium growth by the unique chemistry of freshwater plumes. More Alexandrium cells are typically found within rather than outside the low salinity plumes (e.g., Therriault et al., 1985; Franks and Anderson, 1992), but this could be a result of small-scale physics interacting with the cells migration behavior, or a reflection of higher growth rates within the plume. Freshwater runoff from the heavily forested watershed of the Maine coast contains significant levels of dissolved and particulate organic matter as well as metals and other micronutrients. Some components of this mixture could be critical to the rapid growth of Alexandrium cells. Iron is a likely candidate for a stimulatory micronutrient, as Wells et al. (1991) showed that bioavailable iron was elevated in nearshore waters characteristic of the coastal current, and depleted offshore in the Gulf of Maine.
The measured iron levels were within the range of those that stimulated or limited $A$. tamarense growth in laboratory cultures.

The large number of Alexandrium species involved in HAB events throughout the world makes it difficult to generalize about environmental controls of bloom dynamics. The nutrition of these organisms is not unusual, although mixotrophy has been reported for some Alexandrium species (Jacobson and Anderson, 1996; Legrand and Carlsson, 1998) and more are probably capable of this strategy. Like most phytoplankton, Alexandrium species will respond to anthropogenic nutrient inputs, but there is no evidence that they are preferentially stimulated compared to other phytoplankters, nor is there compelling evidence of any increase in Alexandrium bloom magnitude or frequency as a direct result of pollution or massive nutrient enrichment. Indeed, Alexandrium blooms, including many toxic ones, occur in remote and relatively pristine waters, such as those in Alaska (Hall, 1982) or southern Argentina (Benavides et al., 1995).

One generalization on the dynamics of Alexandrium populations in shallow embayments is that such blooms are heavily dependent upon local hydrographic conditions and the manner in which these factors interact with cell behavior, especially cyst germination, and vertical migration of vegetative cells. Studies of $A$. minutum in a Mediterranean lagoon by Giacobbe et al. (1996) demonstrated that the spring appearance of the species coincided with enhanced rainfall and freshwater runoff, and with stabilization of the water column. Watras et al. (1982) conducted laboratory growth studies and used the results to parameterize a simple model, indicating that for Cape Cod salt ponds, the development of Alexandrium populations depends solely on salinity-dependent temperature regulation of cell division rates. The same model, however, produced a poor prediction of Alexandrium bloom dynamics from the Bay of Fundy, presumably because physical forcings are more influential in population accumulation in such open, tidally stirred waters.

Another example of physical/biological coupling and the importance of stratification and cell swimming behavior in embayments was observed in Salt Pond, a small embayment with a shallow entrance sill that restrict outflowing water to the low density surface layer (Anderson and Stolzenbach, 1985). Diel vertical migration of $A$. fundyense kept cells below that depth during the night, and even when the cells migrated close to the surface during the day, they remained deep enough to avoid transport out of the embayment with the outflowing surface layer. A density-driven exchange mechanism rapidly flushes water from these salt ponds, but the residence time of the Alexandrium cells is much longer due to the limited vertical extent of the migration. This coupling between organism behavior and the hydrography of the system restricts the extent to which vegetative cells and cysts can colonize adjacent waters and allows Alexandrium populations to accumulate to cell concentrations generating high toxicity in shellfish.

The duration of the blooms that have been followed in bays and salt ponds is generally two to three months or less (e.g., Anderson et al., 1983; Han et al., 1992). Giacobbe et al. (1996) describe an $A$. minutum bloom in a Mediterranean lagoon over a six month period, but the cell concentrations were at bloom levels for only two months in spring. In Cape Cod, most Alexandrium blooms develop at water temperatures that are non-optimal for rapid growth of vegetative cells. Perch Pond isolates of Alexandrium grow fastest at $15-20^{\circ} \mathrm{C}$ in the laboratory, but once the water reaches those temperatures in the field, blooms are typically on the decline and new cysts are already falling to the sediments (Anderson et al., 1983). Similarly, Han et al. (1992) found that A. tamarense disappears from the water column of Chinhae Bay, Korea at temperatures well below those that support optimal growth in the laboratory. The implication is that the induction of sexuality 
precludes the long-term persistence of vegetative Alexandrium cells in the plankton.

Laboratory studies suggest that the induction of sexuality in Alexandrium occurs as a result of nutrient limitation, yet this is not well supported by field measurements. One problem in this regard is that gametes are not easily distinguished from vegetative cells in natural populations, and fusing gametes, though distinctive, are rarely observed. Gametes of Alexandrium species have thus never been enumerated in field studies. However, it is possible to recognize duplet cells as well as large, darkly pigmented planozygotes (Anderson, 1980) and to tabulate their abundance through time. Only two studies have attempted to enumerate Alexandrium planozygotes during blooms in order to quantify the importance of encystment in bloom decline (Anderson et al., 1983; Takeuchi et al., 1995). Both show that sexuality is induced well before the bloom peaks, and that during this late stage of bloom development, planozygotes can comprise $20-40 \%$ of the motile population. This underestimates the total percentage of cells that become cysts, however, since it cannot account for the dynamic nature of the zygote sub-population. Each day, some planozygotes fall to the sediments as cysts, but new planozygotes appear following gamete fusion. The estimates do suggest that a large fraction of the bloom population encysts, and thus that bloom decline may be linked more to life cycle transitions than to grazing or other loss factors.

Studies in three Cape Cod salt ponds over two bloom seasons demonstrated that planozygote formation did not coincide with an obvious decrease in ambient nutrients (Anderson et al., 1983). In fact, planozygotes in the plankton and new cysts at the sediment surface were first observed when external nutrients were at or above concentrations equivalent to those measured during the earlier stages of bloom development when vegetative growth was rapid. It may be that as the ambient temperature increased during the blooms, the rates of uptake and metabolism of nutrients increased as well. Thus nutrient concentrations that were sufficient for balanced (but slow) growth at colder, early-bloom temperatures may not have been sufficient to maintain balanced growth when waters warmed and the $A$. tamarense growth rate increased. A gradual decrease in internal nutrient pools would thus occur, leading to nutrient limitation. Alternatively, other factors may regulate sexuality and cyst formation, such as cell density dependence similar to quorum sensing.

Thau Lagoon on the Mediterranean coast of France is another area where Alexandrium bloom dynamics have been intensively studied. Blooms of $A$. catenella are common, but water temperature must be around $20^{\circ} \mathrm{C}$, and a period of calm weather is necessary. Thus blooms occur either in spring or fall, but major wind events will suppress them. Water temperature is probably a proxy for other variables such as turbulence, since dinoflagellates, including A. catenella, are very sensitive to agitation (Therriault et al., 1985). Unlike diatom blooms that are closely related to rain events and flash floods leading to nutrient inputs through the watershed into Thau lagoon, A. catenella does not necessarily bloom following a rain event and can even bloom following three weeks of dry weather. Thus, this species probably relies either on dissolved organic matter produced by diatom blooms (Loureiro et al., 2009) or particulate organic matter from picocyanobacteria (Collos et al., 2009).

From a long-term perspective, A. catenella blooms in Thau lagoon appear to follow a period of oligotrophication, characterized by a steady decline in soluble reactive phosphorus over 30 years (summer values ranged from about 10 to $1 \mu \mathrm{M}$ and winter values from $3 \mu \mathrm{M}$ to undetectable at present; Collos et al., 2009). This is consistent with observations in the Seto Inland Sea of Japan where blooms of Alexandrium species increased following reduction in nutrient inputs (e.g., Imai et al., 2006). Quoting from
Anderson et al. (2002): "as the waters became less eutrophic and large biomass blooms decreased, there was a shift in species composition, leading to a greater prevalence of some that are responsible for shellfish poisonings in humans, such as Alexandrium tamarense and A. catenella". Given the opportunistic behavior of Alexandrium species with respect to limiting nutrient acquisition, their blooms may be independent of eutrophic processes as defined from "classical" dissolved inorganic concentrations only.

\subsection{Loss terms}

Investigation of biological loss terms is a critical but often underrepresented component of attempts to understand and predict Alexandrium bloom dynamics. In Thau lagoon, evidence for biological loss terms include microzooplankton grazing rates that can match gross growth rates of A. catenella (Collos et al., 2004, 2007). In nearby Tarragona harbor in Spain (Garcés et al., 2005), microzooplankton grazing was not considered to be the main cause of $A$. catenella bloom termination. Other loss terms likely included cell lysis, microbial infection by viruses or bacteria, parasite attack, and encystment (Garcés et al., 2005).

Jeong et al. (2010) reviewed ingestion and clearance rates of copepods on Alexandrium spp. among other mixotrophic flagellates. Macrozooplankton grazing is generally thought to be much less important than microzooplankton grazing in regulating populations of $A$. minutum (Calbet et al., 2003). Non-toxic A. tamarense as well as toxic $A$. catenella are found to be excellent prey for the ciliate Favella spp. (Jeong et al., 2010). Among other predators, heterotrophic and mixotrophic dinoflagellates are also known to feed readily upon Alexandrium.

Very little is known about interaction between viruses and Alexandrium species. Loureiro et al. (2009) mention virus densities between 30 and $80 \times 10^{9}$ cells $\mathrm{L}^{-1}$ in cultures of $A$. catenella and these were thought to keep the bacterial population from becoming dominant. Viral linkages to Alexandrium growth and mortality remain one of the major unknowns in the ecology of this genus.

The parasitic dinoflagellate Amoebophrya and the perkinsozoan flagellate Parvilucifera are both known to infect Alexandrium spp. (reviewed by Salomon and Imai, 2006). The latter parasite has now been found to infect the mobile zygote or the pellicle cyst of $A$. minutum, but not the thick-walled resting cyst or hypnozygote (Figueroa et al., 2008b). In addition, strain-specific host resistance to $P$. sinerae was documented for A. minutum (Figueroa et al., 2010). In Northern Britanny, Amoebophrya was shown to regulate populations of $A$. minutum (Chambouvet et al., 2008; Montagnes et al., 2008). Variables such as turbulence appear to reduce parasite infection for $A$. minutum (Llaveria et al., 2010). Infestation by Amoebophrya was also shown to be a major factor contributing to the decline of two blooms of A. catenella blooms in Puget Sound, Washington, USA (Nishitani et al., 1984). Although it has not been well documented with empirical data, parasites could be more important than microzoplankton as loss factors (Montagnes et al., 2008).

\section{Modeling}

Models of various types have been developed to describe and investigate physiology, toxicity, and bloom dynamics of Alexandrium. At the physiological level, growth and PSP toxin content of $A$. fundyense was modeled by John and Flynn (2002) from data for ammonium- and nitrate-grown cultures that were either P-replete or P-stressed. The model demonstrated a good fit to almost all cellular quota data and allowed the authors to examine the consequences of recycling toxin- $\mathrm{N}$, versus not producing toxins at 
all. These calculations suggested that there may not be a specific evolutionary advantage to toxin production, possibly explaining the significant variability in PSP toxin synthesis capabilities within the genus Alexandrium.

An extension of this model (Flynn, 2002) simulated PSP toxin content for $A$. fundyense in response to $\mathrm{N}$ and $\mathrm{P}$ nutritional status within a vertical water column in which the organism migrated. Growth in an N-limited water column resulted in a continual (although low level) toxin production with a large population biomass. A sequence of P-stress and nutrient re-feeding events during vertical migration showed an enhancement of PSP toxin content even with only moderately elevated N:P ratios. Although the final biomass was lower in these P-limited simulations, total toxin production was much higher. Vertical migration in stratified waters with moderately high $\mathrm{N}: \mathrm{P}$ conditions could thus result in the formation of highly toxic populations of Alexandrium.

The role of resting cysts on the development of $A$. minutum blooms in a typical Mediterranean semi-enclosed water body (Arenys de Mar Harbor, NW Mediterranean) was studied by means of matrix and dynamic population models (Estrada et al., 2010). A series of scenarios were tested to determine whether excystment and encystment fluxes and changes in the dormancy period had a major effect on bloom intensity and duration. The results highlighted the importance of knowing not only the magnitude and variability of growth and life-cycle transition rates, but also those of loss rates (both in the water column and in the sediment) due to physical or biological factors. Given the maximum but low encystment rates determined for $A$. minutum in the study area $\left(0.01 \mathrm{~d}^{-1}\right)$, this process reduced the peak concentrations of vegetative cells but did not have a major effect on bloom termination. Excystment fluxes could enhance population densities of vegetative cells during times of low or negative net growth rate and during the initial phases of a bloom. Once exponential growth began, however, additional excystment had a negligible effect on bloom magnitude. More complex models will be needed to explore the implications of different life-cycle strategies in a wider natural ecological context.

Models have also been developed to simulate Alexandrium population dynamics in the field. These typically have two components - a hydrographic model, and a biological submodel. This type of physical-biological model was developed for $A$. tamarense blooms in the lower St. Lawrence estuary in eastern Canada in order to explore the interactions between cyst germination, cellular growth and water circulation and to identify the effect of physical processes on bloom development and transport across the estuary (Fauchot et al., 2008). The biological model was parameterized using an observed $A$. tamarense cyst distribution, cyst germination rate and timing, and $A$. tamarense growth limitation by temperature and salinity. The model successfully reproduced the timing of the A. tamarense bloom in 1998 , its coincidence with the combined plumes from two rivers on the north shore of the estuary, and the temporal variations in the north-south gradients in cell concentrations.

Another well-developed physical-biological model is that used to investigate A. fundyense and PSP dynamics in the Gulf of Maine (e.g., McGillicuddy et al., 2005). This model is based on a hydrographic submodel that can realistically simulate water motion over this large region, as driven by winds, tides, stratification, river run off, and large-scale forcing from the open ocean. A second submodel is then coupled to the hydrography, simulating the germination of Alexandrium cysts from seed beds in the region, and the subsequent growth of the population, regulated by temperature, salinity, sunlight and nutrients. The timing and rates of cyst germination and cell growth are parameterized from laboratory experiments on cultures of $A$. fundyense (Stock et al., 2005). A temperature-dependent mortality function incorporates a range of loss factors, including grazing and encystment. This model has demonstrated high fidelity at reproducing observations (Stock et al., 2005; He et al., 2008) and thus has been heavily used for hindcasts (looking at past events to understand underlying mechanisms; He et al., 2008; Li et al., 2009). The model is also being used to issue weekly nowcasts and forecasts (looking forward 3 or 4 days) and even seasonal or annual forecasts (McGillicuddy et al., 2011).

\section{Overview and summary}

The ability of Alexandrium species to colonize multiple habitats and to persist over large regions through time is testimony to the adaptability and resilience of this important organism. Alexandrium species are not known for rapid or "explosive" growth rates. At large spatial scales ( $>100 \mathrm{~km}$ ), population growth is typically not reflected in monospecific blooms but rather in moderate biomass levels and co-occurrence with other species. Blooms are not particularly long-lasting (days to weeks), and seem restricted in time by life cycle transitions. The cyst stage is clearly important in the population dynamics of many Alexandrium species, but the nature of this linkage varies among habitats. In shallow embayments, cysts and motile cell blooms are tightly coupled, whereas in large temperate estuaries and open coastal waters, the linkage is more difficult to define and quantify. In both of these habitats, most of the cysts in the sediments do not germinate due to bioturbation, burial, and inhibition of germination by anoxia. Even when only the cysts in surface sediments are considered, the bulk of the widely distributed cysts in deeper waters may germinate too slowly or too far from suitable growth conditions to be a factor in coastal blooms.

Estimates of the inoculum size from excystment are small - on the order of tens to hundreds of cells per liter, suggesting that major blooms require multiple, sustained vegetative divisions that in turn depend greatly on environmental conditions affecting motile cells. Nevertheless, the size of an excystment inoculum can have a bearing on the magnitude of a bloom, especially if that bloom is limited temporally due to seasonal temperatures or to some form of endogenous regulation of excystment and encystment.

In small-scale blooms in embayments and in widespread coastal blooms, physical/biological coupling is a critical feature of population accumulation, growth, and dispersal. Behavioral adaptations such as vertical migration are important features in this regard. Bloom termination is clearly linked to life cycle transitions, although the relative importance of encystment relative to grazing or other loss factors has not been sufficiently investigated.

In one sense, Alexandrium species appear to use a type of $\mathrm{r}$ selection strategy, producing many "offspring" in the form of cysts, only a few of which ever germinate to inoculate blooms. On the other hand, a complex life history and a low growth rate are often considered $K$-strategies. The production of toxins and other allelochemicals to mediate inter-specific interactions is also more typical of the latter adaptive strategy. This group of dinoflagellates does not therefore easily fit into such fixed categories.

Overall, the Alexandrium species that have been studied in detail have proven to be remarkably resilient and capable of colonizing a wide spectrum of habitats and hydrographic regimes. It is thus of no surprise that the biogeographic range of these species has expanded in recent times and that associated PSP outbreaks remain a significant global problem.

\section{Acknowledgements}

Support to DMA was provided by the National Institute of Environmental Health Sciences (1-P50-ES012742) and the National Science Foundation through the Woods Hole Center for Oceans 
and Human Health (OCE-0430724), and by NOAA Grants NA09NOS4780193, NA06OAR4170021 and NA06NOS4780245. Research funding to ADC and previously to TJA was furnished under the PACES Programme (Coast WP2) from the Helmholtz Society initiative Earth and Environment. Support to TJA was obtained by the research funding program LOEWE (LandesOffensive zur Entwicklung Wissenschaftlich-ökonomischer Exzellenz) of Hesse's Ministry of Higher Education, Research, and the Arts. Support to EM and YC was provided by grants from the French National Programme "Ecosphère Continentale et Côtière-EC2CO and from the "Fondation pour la Recherche sur la BiodiversitéINVALEX project (AAP-IN-2009-036). This is ECOHAB contribution number 673. [SS]

\section{References}

Abadie, E., Amzil, Z., Belin, C., Comps, M.-A., Elziere-Papayanni, P., Lassus, P., Le Bec, C., Marcaillou-Le Baut, C., Nezan, E., Poggi, R., 1999. Contamination de l'etang de Thau par Alexandrium tamarense: Épisode de novembre à décembre 1998. Ifremer, Plouzané, France, p. 44.

Achiha, H., Iwasaki, H., 1990. Growth characteristics of the toxic dinoflagellate, Alexandrium tamarense. Jpn. J. Phycol. 38, 31-59.

Adachi, M., Kanno, T., Matsubara, T., Nishijima, T., Itakura, S., Yamaguchi, M., 1999. Promotion of cyst formation in the toxic dinoflagellate Alexandrium (Dinophyceae) by natural bacterial assemblages from Hiroshima Bay, Japan. Mar. Ecol. Prog. Ser. 191, 175-185.

Adachi, M., Sako, Y., Ishida, Y., 1994. Restriction fragment length polymorphism of ribosomal DNA internal transcribed spacer and 5.8S regions in Japanese Alexandrium species (Dinophyceae). J. Phycol. 30, 857-863.

Alpermann, T., Beszteri, B., John, U., Tillmann, U., Cembella, A., 2009. Implications of life-history transitions on the population genetic structure of the toxigenic marine dinoflagellate Alexandrium tamarense. Mol. Ecol. 18, 2122-2133.

Alpermann, T.J., John, U., Medlin, L.K., Edwards, K.J., Hayes, P.K., Evans, K.M., 2006. Six new microsatellite markers for the toxic marine dinoflagellate Alexandrium tamarense. Mol. Ecol. Notes 6, 1057-1059.

Alpermann, T.J., Tillmann, U., Beszteri, B., Cembella, A.D., John, U., 2010. Phenotypic variation and genotypic diversity in a planktonic population of the toxigenic marine dinoflagellate Alexandrium tamarense (Dinophycae). J. Phycol. 46, 18 32.

Andersen, R.A., Berges, J.A., Harrison, P.J., Watanabe, M.M., 2005. Recipes for freshwater and seawater media. In: Andersen, R.A. (Ed.), Algal Culturing Techniques. Elsevier, Amsterdam, pp. 429-538.

Anderson, D.M., 1980. The effects of temperature conditioning on the development and germination of Gonyaulax tamarensis (Dinophyceae) hypnozygotes. J. Phycol. $16,166-172$.

Anderson, D.M., 1998. Physiology and bloom dynamics of toxic Alexandrium species, with emphasis on life cycle transitions. In: Anderson, D.M., Cembella, A.D., Hallegraeff, G.M. (Eds.), The Physiological Ecology of Harmful Algal Blooms. Springer-Verlag, Heidelberg, pp. 29-48.

Anderson, D.M., Keafer, B.A., 1987. An endogenous annual clock in the toxic marine dinoflagellate Gonyaulax tamarensis. Nature 325, 616-617.

Anderson, D.M., Lindquist, N.L., 1985. Time-course measurements of phosphorus depletion and cyst formation in the dinoflagellate Gonyaulax tamarensis Lebour. J. Exp. Mar. Biol. Ecol. 86, 1-13.

Anderson, D.M., Morel, F.M.M., 1979. The seeding of two red tide blooms by the germination of benthic Gonyaulax tamarensis hypnocysts. Estuar. Coast. Mar. Sci. 8, 279-293.

Anderson, D.M., Rengefors, K., 2006. Community assembly and seasonal succession of marine dinoflagellates in a temperate estuary - the importance of life cycle events and predation. Limnol. Oceanogr. 51 (2), 860-873.

Anderson, D.M., Stolzenbach, K.D., 1985. Selective retention of two dinoflagellates in a well-mixed estuarine embayment: the importance of diel vertical migration and surface avoidance. Mar. Ecol. Prog. Ser. 25, 39-50.

Anderson, D.M., Wall, D., 1978. Potential importance of benthic cysts of Gonyaulax tamarensis and G. excavata in initiating toxic dinoflagellate blooms. J. Phycol. 14, 224-234.

Anderson, D.M., Aubrey, D.G., Tyler, M.A., Coats, D.W., 1982. Vertical and horizontal distributions of dinoflagellate cysts in sediments. Limnol. Oceanogr. 27 (4), 757-765.

Anderson, D.M., Chisholm, S.W., Watras, C.J., 1983. The importance of life cycle events in the population dynamics of Gonyaulax tamarensis. Mar. Biol. 76, 179183.

Anderson, D.M., Glibert, P.M., Burkholder, J.M., 2002. Harmful algal blooms and eutrophication: nutrient sources, composition and consequences. Estuaries 25, 704-726.

Anderson, D.M., Keafer, B.A., Geyer, W.R., Signell, R.P., Loder, T.C., 2005a. Toxic Alexandrium blooms in the western Gulf of Maine: the plume advection hypothesis revisited. Limnol. Oceanogr. 50 (1), 328-345.

Anderson, D.M., Kulis, D.M., Binder, B.J., 1984. Sexuality and cyst formation in the dinoflagellate Gonyaulax tamarensis, cyst yield in batch cultures. J. Phycol. 20, 418-425.
Anderson, D.M., Kulis, D.M., Doucette, G.J., Gallagher, J.C., Balech, E., 1994. Biogeography of toxic dinoflagellates in the genus Alexandrium from the northeastern United States and Canada. Mar. Biol. 120, 467-478.

Anderson, D.M., Kulis, D.M., Keafer, B.A., Gribble, K.E., Marin, R., Scholin, C.A., 2005b. Identification and enumeration of Alexandrium spp. from the Gulf of Maine using molecular probes. Deep-Sea Res. Pt. II 52 (19-21), 2467-2490.

Anderson, D.M., Kulis, D.M., Sullivan, J.J., Hall, S., Lee, C., 1990. Dynamics and physiology of saxitoxin production by the dinoflagellates Alexandrium spp. Mar. Biol. 104, 511-524.

Anderson, D.M., Stock, C.A., Keafer, B.A., Bronzino Nelson, A., Thompson, B., McGillicuddy, D.J., Keller, M., Matrai, P.A., Martin, J., 2005c. Alexandrium fundyense cyst dynamics in the Gulf of Maine. Deep-Sea Res. Pt. II 52 (19-21), 2522-2542.

Anderson, D.M., Taylor, C.D., Armbrust, E.V., 1987. The effects of darkness and anaerobiosis on dinoflagellate cyst germination. Limnol. Oceanogr. 32, 340351.

Anderson, D.M., Townsend, D.W., McGillicuddy, Jr., D.J., Turner, J.T. (Eds.), 2005d. The ecology and oceanography of toxic Alexandrium fundyense blooms in the Gulf of Maine. Deep-Sea Res. Pt. II 52 (19-21) 2365-2876.

Arzul, G., Seguel, M., Guzman, L., Erard-LeDenn, E., 1999. Comparison of allelopathic properties in three toxic Alexandrium species. J. Exp. Mar. Biol. Ecol. 232, 285 295.

Balech, E., 1964. El plancton del Mar del Plata durante el periodo 1961-1962 (Buenos Aires, Argentina). Bol. Inst. Biol. Mar. Mar del Plata 4, 1-59.

Balech, E., 1967. Dinoflagelados nuevos o interesantes del Golfo de Mexico y Caribe. Rev. Mus. Arg. C. Nat. 'B. Rivadavia' Hidrobiologia 2, 77-126.

Balech, E., 1971. Microplancton del Atlantico ecuatorial oeste (Equalant I). Armada Argentina Servicio de Hidrografia Naval, Republica Argentina.

Balech, E., 1979. Tres Dinoflagelados nuevos o interesantes de aguas brasilenas. Bolm. Inst. Oceanogr. S. Paulo 28, 55-64.

Balech, E., 1985. The genus Alexandrium or Gonyaulax of the tamarensis group. In: Anderson, D.M., White, A.W., Baden, D.G. (Eds.), Toxic Dinoflagellates. Elsevier, Amsterdam, pp. 33-38.

Balech, E., 1989. Redescription of Alexandrium minutum Halim (Dinophyceae) type species of the genus Alexandrium. Phycologia 28, 206-211.

Balech, E., 1990. Four new dinoflagellates. Helgoländer Meeresun. 44, 387-396.

Balech, E., 1994. Three new species of the genus Alexandrium (Dinoflagellata). Trans Am. Microsc. Soc. 113, 216-220.

Balech, E., 1995. The Genus Alexandrium Halim (Dinoflagellata). Sherkin Island Marine Station, Sherkin Island, Co. Cork, Ireland.

Balech, E., Tangen, K., 1985. Morphology and taxonomy of toxic species in the tamarensis group (Dinophyceae): Alexandrium excavatum (Braarud) comb. nov. and Alexandrium ostenfeldii (Paulsen) comb. nov. Sarsia 70, 333-343.

Balech, E., de Mendiola, B.R., 1977. Un nuevo Gonyaulax productor de hemotalasia en Peru. Neotropica 23, 49-54.

Band-Schmidt, C.J., Lechuga-Devéze, C.H., Kulis, D.M., Anderson, D.M., 2003. Culture studies of Alexandrium affine (Dinophyceae), a non-toxic cyst forming dinoflagellate from Bahia Concepcion, Gulf of California. Bot. Mar. 46, 44-54.

Benavides, H., Prado, L., Diaz, S., Carreto, J.J., 1995. An exceptional bloom of Alexandrium catenella in the Beagle Channel, Argentina. In: Lassus, P., Arzul, G., Erard, E., Gentien, P., Marcaillou, C. (Eds.), Harmful Marine Algal Blooms Lavoiser Science Publishers, Paris, pp. 113-119.

Biecheler, B., 1952. Recherches sur les Péridinens. Bull. Biol. France Belgique Suppl. $36,1-149$.

Bolch, C.J.S., de Salas, M.F., 2007. A review of the molecular evidence for ballast water introduction of the toxic dinoflagellates Gymnodinium catenatum and the Alexandrium "tamarensis complex" to Australasia. Harmful Algae 6, 465-485.

Boczar, B.A., Beitler, M.K., Liston, J., Sullivan, J.J., Cattolico, R.A., 1988. Paralytic shellfish toxins in Protogonyaulax tamarensis and Protogonyaulax catenella in axenic culture. Plant Physiol. 88, 1285-1290.

Boyer, G.L., Sullivan, J.J., Andersen, R.J., Harrison, P.J., Taylor, F.J.R., 1987. Effects of nutrient limitation on toxin production and composition in the marine dinoflagellate Protogonyaulax tamarensis. Mar. Biol. 96, 123-128.

Brand, L.E., 1981. Genetic variability in reproduction rates in marine phytoplankton populations. Evolution 35, 1117-1127.

Bravo, I., Figueroa, R.I., Garcés, E., Fraga, S., Massanet, A., 2010. The intricacies of dinoflagellate pellicle cysts: the example of Alexandrium minutum cysts from a bloom-recurrent area (Bay of Baiona, NW Spain). Deep-Sea Res. Pt. II 57 (3-4), 166-174.

Bravo, I., Vila, M., Maso, M., Ramilo, I., Figueroa, R.I., 2008. Alexandrium catenella and Alexandrium minutum blooms in the Mediterranean Sea: toward the identification of ecological niches. Harmful Algae 7, 515-522.

Brosnahan, M.L., Kulis, D.M., Solow, A.R., Erdner, D.L., Percy, L., Lewis, J., Anderson, D.M., 2010. Outbreeding lethality between toxic Group I and non toxic Group III Alexandrium tamarense spp. isolates: Predominance of heterotypic encystment and implications formating interactions and biogeography. Deep-Sea Res. Pt. II 57, 175-189.

Calbet, A., Vaqué, D., Felipe, J., Vila, M., Sala, M.M., Alcaraz, M., Estrada, M., 2003. Relative grazing impact of microzooplankton and mesozooplankton on a bloom of the toxic dinoflagellate Alexandrium minutum. Mar. Ecol. Prog. Ser. 259, 303309.

Carignan, M.O., Montoya, N.G., Carreto, J.I., 2002. Long-term effects of ultraviolet radiation on the composition of pigment and mycosporine-like amino acids (MAAs) composition in Alexandrium catenella. In: Arzul, G. (Ed.), Aquaculture, Environment and Marine Phytoplankton. Proceedings of a Symposium Held in Brest. 21-23 May, 2001, no. 34, (Actes Colloq. IFREMER), pp. 191-207. 
Carlsson, P., Edling, H., Béchemin, C., 1998. Interactions between a marine dinoflagellate (Alexandrium catenella) and a bacterial community utilizing riverine humic substances. Aquat. Microb. Ecol. 16, 65-80.

Casabianca, S., Penna, A., Pecchioli, E., Jordi, A., Basterretxea, G., Vernesi, C., 2011 Population genetic structure and connectivity of the harmful dinoflagellate Alexandrium minutum in the Mediterranean Sea. Proc. R. Soc. B, doi:10.1098 rspb.2011.0708.

Castell Perez, C., Roy, S., Levasseur, M., Anderson, D.M., 1998. Control of germination of Alexandrium tamarense (Dinophyceae) cysts from the lower St. Lawrence estuary (Canada). J. Phycol. 34, 242-249.

Cembella, A.D., 1998. Ecophysiology and metabolism of paralytic shellfish toxins in marine microalgae. In: Anderson, D.M., Cembella, A.D., Hallegraeff, G.M. (Eds.), Physiological Ecology of Harmful Algal Blooms. Springer, Berlin, Heidelberg, New York, pp. 381-403.

Cembella, A.D., 2003. Chemical ecology of eukaryotic microalgae in marine ecosystems. Phycologia 42, 420-447.

Cembella, A.D., Destombe, C., 1996. Genetic differentiation among Alexandrium populations from eastern Canada. In: Yasumoto, T., Oshima, Y., Fukuyo, Y. (Eds.), Harmful and Toxic Algal Blooms. Intergovernmental Oceanographic Commission of UNESCO, Paris, pp. 447-450.

Cembella, A., Krock, B., 2007. Cyclic imine toxins: chemistry, biogeography, biosynthesis and pharmacology. In: Botana, L.M. (Ed.), Seafood and Freshwater Toxins: Pharmacology, Physiology, and Detection. CRC Press, Boca Raton, FL, pp. 561580

Cembella, A.D., Antia, N.J., Harrison, P.J., 1984. The utilization of inorganic and organic phosphorus compounds as nutrients by eukaryotic microalgae: a multidisciplinary perspective: part 1. Crit. Rev. Microbiol. 10, 317-391.

Cembella, A.D., Bauder, A.G., Lewis, N.I., Quilliam, M.A., 2001. Association of the gonyaulacoid dinoflagellate Alexandrium ostenfeldii with spirolide toxins in size fractionated plankton. J. Plankton Res. 23, 1413-1419.

Cembella, A.D., Lewis, N.I., Quilliam, M.A., 2000. The marine dinoflagellate Alexandrium ostenfeldii (Dinophyceae) as the causative organism of spirolide shellfish toxins. Phycologia 39, 67-74.

Cembella, A.D., Sullivan, J.J., Boyer, G.L., Taylor, F.J.R., Andersen, R.J., 1987. Variation in paralytic shellfish toxin composition within the Protogonyaulax tamarensis catenella species complex; red tide dinoflagellates. Biochem. Syst. Ecol. 15, 171186.

Cembella, A.D., Turgeon, J., Therriault, J.C., Beland, P., 1988. Spatial distribution of Protogonyaulax tamarensis resting cysts in nearshore sediments along the north coast of the lower St. Lawrence estuary. J. Shellfish Res. 7, 597-610.

Chambouvet, A., Morin, P., Marie, D., Guillou, L., 2008. Control of toxic marine dinoflagellate blooms by serial parasitic killers. Science 322, 1254-1257.

Chang, F.H., McClean, M., 1997. Growth responses of Alexandrium minutum (Dinophyceae) as a function of three different nitrogen sources and irradiance. N. Z. J. Mar. Freshwater Res. 31, 1-7.

Chen, W., Wangersky, P.J., 1996. Production of dissolved organic carbon in phytoplankton cultures as measured by high-temperature catalytic oxidation and ultraviolet photo-oxidation methods. J. Plankton Res. 18, 1201-1211.

Collos, Y., Bec, B., Jauzein, C., Abadie, E., Laugier, T., Lautier, J., Pastoureaud, A. Souchu, P., Vaquer, A., 2009. Oligotrophication and emergence of picocyanobacteria and a toxic dinoflagellate in Thau lagoon, southern France. J. Sea Res. $61,68-75$

Collos, Y., Gagne, C., Laabir, M., Vaquer, A., 2004. Nitrogenous nutrition of Alexandrium catenella (Dinophyceae) in cultures and in Thau lagoon, southern France. J. Phycol. 40, 96-103.

Collos, Y., Lespilette, M., Vaquer, A., Laabir, M., Pastoureaud, A., 2006. Uptake and accumulation of ammonium by Alexandrium catenella during nutrient pulses. Afr. J. Mar. Sci. 28, 313-318.

Collos, Y., Vaquer, A., Laabir, M., Abadie, E., Laugier, T., Pastoureaud, A., Souchu, P., 2007. Contribution of several nitrogen sources to growth of Alexandrium catenella during blooms in Thau lagoon, Southern France. Harmful Algae 6, 781-789.

Costas, E., 1990. Genetic variability in growth rates of marine dinoflagellates. Genetica 83, 99-102.

Crespo, B.G., Keafer, B.A., Ralston, D.K., Lind, H., Farber, D., Anderson, D.M., Dynamics of Alexandrium fundyense blooms and shellfish toxicity in the Nauset Marsh System of Cape Cod (Massachusetts, USA). Harmful Algae, doi:10.1016 j.hal.2011.08.009, in press

Destombe, C., Cembella, A., 1990. Mating-type determination, gametic recognition and reproductive success in Alexandrium excavatum (Gonyaulacales, Dinophyta), a toxic red-tide dinoflagellate. Phycologia 29, 316-325.

Diercks, S., Medlin, L.K., Metfies, K., 2008. Colorimetric detection of the toxic dinoflagellate Alexandrium minutum using sandwich hybridization in a microtiter plate assay. Harmful Algae 7 (2), 137-145.

Diercks-Horn, S., Metfies, K., Jäckel, S., Medlin, L.K., 2011. The ALGADEC device: A semi-automated rRNA biosensor for the detection of toxic algae. Harmful Algae $10,395-401$

Doblin, M., Legrand, C., Carlsson, P., Hummert, C., Granéli, E., Hallegraeff, G., 2001 Uptake of humic substances by the toxic dinoflagellate Alexandrium catenella. In: Hallegraeff, G.M., Blackburn, S.I., Bolch, C.J., Lewis, R.J. (Eds.), Harmful Algal Blooms 2000. UNESCO, Paris, pp. 336-339.

Doucette, G.J., Cembella, A.D., Boyer, G.L., 1989. Cyst formation in the red tide dinoflagellate Alexandrium tamarense (Dinophyceae): effects of iron stress. J. Phycol. 25, 721-731.

Dyhrman, S.T., Anderson, D.M., 2003. Urease activity in cultures and field populations of the toxic dinoflagellate Alexandrium. Limnol. Oceanogr. 48, 647-655.
Dyhrman, S.T., Erdner, D., La Du, J., Galac, M., Anderson, D.M., 2006. Molecular quantification of toxic Alexandrium fundyense in the Gulf of Maine using realtime PCR. Harmful Algae 5, 242-250.

Emura, A., Matsuyama, Y., Oda, T., 2004. Evidence for the production of a novel proteinaceous hemolytic exotoxin by dinoflagellate Alexandrium taylori. Harmful Algae 29-37.

Erard-Le Denn, E., Desbruyeres, E., Olu, K., 1993. Alexandrium minutum: resting cyst distribution in the sediments collected along the Brittany coast, France. In: Smayda, T.J., Shimizu, Y. (Eds.), Toxic Phytoplankton Blooms in the Sea. Elsevier, Amsterdam, pp. 109-114

Erdner, D.L., Percy, L., Keafer, B., Lewis, J., Anderson, D.M., 2010. A quantitative realtime PCR assay for the identification and enumeration of Alexandrium cysts in marine sediments. Deep-Sea Res. Pt. II 57 (3-4), 279-287.

Erdner, D.L., Richlen, M., McCauley, L.A.R., Anderson, D.M., 2011. Intrapopulation diversity and dynamics of a widespread bloom of the toxic dinoflagellate Alexandrium fundyense. PLoS One 6 (7), e22965, doi:10.1371/journal.pone.0022965

Estrada, M., Solé, J., Anglès, S., Garcés, E., 2010. The role of resting cysts in Alexandrium minutum population dynamics. In: Garcés, E., Montresor, M., Lewis, J., Rengefors, K., Anderson, D.M. (Eds.), Phytoplankton Life Cycles and Their Impacts on the Ecology of Harmful Algal Blooms, Deep-Sea Res. Pt. II 57 (3-4), 308-321.

Fagerberg, T. Carlsson, P., Lundgren, M., 2009. A large molecular size fraction of riverine high molecular weight dissolved organic matter (HMW DOM) stimulates growth of the harmful dinoflagellate Alexandrium minutum. Harmful Algae $8,823-831$.

Falkowski, P.G., Owens, T.G., 1978. Effects of light intensity on photosynthesis and dark respiration in six species of marine phytoplankton. Mar. Biol. 45, 289-295.

Fauchot, J., Saucier, F.J., Levasseur, M., Roy, S., Zakardjian, B., 2008. Wind-driven river plume dynamics and toxic Alexandrium tamarense blooms in the St. Lawrence estuary (Canada): A modeling study. Harmful Algae 7, 214-227.

Figueroa, R.I., Bravo, I., Garcés, E., 2005. Effects of nutritional factors and different parental crosses on the encystment and excystment of Alexandrium catenella (Dinophyceae) in culture. Phycologia 44, 658-670.

Figueroa, R.I., Bravo, I., Garcés, E., 2006. Multiple routes of sexuality in Alexandrium taylori (Dinophyceae) in culture. J. Phycol. 42, 1028-1039.

Figueroa, R.I., Bravo, I., Garcés, E., 2008a. The significance of sexual versus asexual cyst formation in the life cycle of the noxious dinoflagellate Alexandrium peruvianum. Harmful Algae 7 (5), 653-663.

Figueroa, R.I., Garces, E., Bravo, I., 2007. Comparative study of the life cycles of Alexandrium tamutum and Alexandrium minutum (Gonyaulacales, Dinophyceae) in culture. J. Phycol. 43, 1039-1053.

Figueroa, R.I., Garcés, E., Camp, J., 2010. Reproductive plasticity and local adaptation in the host-parasite system formed by the toxic Alexandrium minutum and the dinoflagellate parasite Parvilucifera sinerae. Harmful Algae 10, 56-63.

Figueroa, R.I., Garcés, E., Massana, R., Camp, J., 2008b. Description, host-specificity, and strain selectivity of the dinoflagellate parasite Parvilucifera sinerae sp. nov. (Perkinsozoa). Protist 159, 563-578.

Fistarol, G.O., Legrand, C., Rengefors, K., Granéli, E., 2004. Temporary cyst formation in phytoplankton: a response to allelopathic competitors? Environ. Microbiol. 6, 791-798.

Flynn, K.J., 2002. Toxin production in migrating dinoflagellates: a modelling study of PSP producing Alexandrium. Harmful Algae 1, 147-155.

Flynn, K.J., Flynn, K., 1998. The release of nitrite by marine dinoflagellates-development of a mathematical simulation. Mar. Biol. 130, 455-470.

Flynn, K., Clark, D.R., Xue, Y., 2008. Modelling the release of dissolved organic matter by phytoplankton. J. Phycol. 44, 1171-1187.

Flynn, K., Jones, K.J., Flynn, K.J., 1996. Comparisons among species of Alexandrium (Dinophyceae) grown in nitrogen- or phosphorus-limiting batch culture. Mar. Biol. 126, 9-18.

Fraga, S., Gallager, S.M., Anderson, D.M., 1989. Chain-forming dinoflagellates: an adaptation to red tides. In: Okaichi, T., Anderson, D.M., Nemoto, T. (Eds.), Red Tides: Biology, Environmental and Science and Toxicology. Elsevier, New York, pp. 281-284.

Franco, J.M. Fraga, S. Zapata, M., Bravo, I. Fernandez, P., Ramilo, I. 1995. Comparison between different strains of genus Alexandrium of the minutum group. In: Lassus, P., Arzul, G., Erard-Le Denn, E., Gentien, P., Marcaillou-Le Baut, C. (Eds.), Harmful Marine Algal Blooms. Lavoisier Publishing, Paris, pp. 53-58.

Franks, P.J.S., Anderson, D.M., 1992. Alongshore transport of a toxic phytoplankton bloom in a buoyancy current: Alexandrium tamarensis in the Gulf of Maine. Mar. Biol. 112, 153-164.

Frehi, H., Couté, A., Mascarell, G., Perrette-Gallet, C., Ayada, M., Kara, M.H., 2007. Harmful and red-tide dinoflagellates in the Annaba bay (Algeria). C. R. Biol. 330, 615-628.

Fukuyo, Y., Yoshida, K., Inoue, H., 1985. Protogonyaulax in Japanese costal waters. In: Anderson, D.M., White, A.W., Baden, D.G. (Eds.), Toxic Dinoflagellates. Elsevier, Amsterdam, pp. 27-32.

Gaarder, K.R., 1954. Dinoflagellatae from the Michael Sars North Atlantic Deep Sea Expedition 1910. Report on the Scientific Results of the Michael Sars North Atlantic Deep Sea Expedition. University of Bergen, pp. 1-62.

Gagnon, R., Levasseur, M., Weise, A.M., Fauchot, J., Campbell, P.G.C., Weissenboeck, B.J., Merzouk, A., Gosselin, M., Vigneault, B., 2005. Growth stimulation of Alexandrium tamarense (Dinophyceae) by humic substances from the Manicouagan river (Eastern Canada). J. Phycol. 41, 489-497.

Galluzzi, L., Bertozzini, E., Penna, A., Perini, F., Garcés, E., Magnani, M., 2010. Analysis of rRNA gene content in the Mediterranean dinoflagellate Alexandrium catenella 
and Alexandrium taylori: implications for the quantitative real-time PCR-based monitoring methods. J. Appl. Phycol. 22, 1-9.

Galluzzi, L., Penna, A., Bertozzini, E., Giacobbe, M.G., Vila, M., Garcés, E., Prioli, S. Magnani, M., 2005. Development of a qualitative PCR method for the Alexandrium spp. (Dinophyceae) detection in contaminated mussels (Mytilus galloprovincialis). Harmful Algae 4, 973-983.

Galluzzi, L., Penna, A., Bertozzini, E., Vila, M., Garcés, E., Magnani, M., 2004. Development of a real-time PCR assay for rapid detection and quantification of Alexandrium minutum (a dinoflagellate). Appl. Environ. Microbiol. 70, 11991206.

Garcés, E., Delgado, M., Masò, M., Camp, J., 1998. Life history and in situ growth rates of Alexandrium taylori (Dinophyceae, Pyrrhophyta). J. Phycol. 34, 880-887.

Garcés, E., Vila, M., Maso, M., Sampedro, R., Giacobbe, M.G., Penna, A., 2005. Taxonspecific analysis of growth and mortality rates of harmful dinoflagellates during bloom conditions. Mar. Ecol. Prog. Ser. 301, 67-79.

Genovesi, B., Laabir, M., Masseret, E., Collos, Y., Vaquer, A., Grzebyk, D., 2009. Dormancy and germination features in resting cysts of Alexandrium tamarense species complex (Dinophyceae) can facilitate bloom formation in a shallow lagoon (Thau, southern France). J. Plankton Res. 31, 1209-1224.

Genovesi, B., Shin-Grzebyk, M.S., Grzebyk, D., Laabir, M., Gagnaire, P.A., Vaquer, A. Pastoureaud, A., Lasserre, B., Collos, Y., Berrebi, P., Masseret, E., 2011. Assessment of cryptic species diversity within blooms and cyst bank of the Alexandrium tamarense complex (Dinophyceae) in a Mediterranean lagoon facilitated by semi-multiplex PCR. J. Plankton Res. 33, 405-414.

Gescher, C., Metfies, K., Medlin, L.K., 2008. The ALEX CHIP-development of a DNA chip for identification and monitoring of Alexandrium. Harmful Algae 7, 485-494.

Giacobbe, M.G., Yang, X., 1999. The life history of Alexandrium taylori (Dinophyceae). J. Phycol. 35, 331-338.

Giacobbe, M.G., Oliva, F.D., Maimone, G., 1996. Environmental factors and seasonal occurrence of the dinoflagellate Alexandrium minutum, a PSP potential producer, in a mediterranean lagoon. Estuar. Coast. Shelf Sci. 42, 539-549.

Gribble, K.E., Keafer, B.A., Quilliam, M.A., Cembella, A.D., Kulis, D.M., Manahan, A., Anderson, D.M., 2005. Distribution and toxicity of Alexandrium ostenfeldii (Dinophyceae) in the Gulf of Maine, USA. Deep-Sea Res. Pt. II 52, 2745-2763.

Guillou, L., Nezan, E., Cueff, V., Erard-Le Denn, E., Cambon-Bonavita, M.A., Gentien, P., Barbier, G., 2002. Genetic diversity and molecular detection of three toxic dinoflagellate genera (Alexandrium, Dinophysis, and Karenia) from French coasts. Protist 153, 223-238.

Guindon, S., Gascuel, O., 2003. A simple, fast, and accurate algorithm to estimate large phylogenies by maximum likelihood. Syst. Biol. 52 (5), 696-704.

Hackett, J.D., Scheetz, T.E., Yoon, H.S., Soares, M.B., Bonaldo, M.F., Casavant, T.L., Bhattacharya, D., 2005. Insights into a dinoflagellate genome through expressed sequence tag analysis. BMC Genomics $6,80$.

Hackett, J.D., Wisecaver, J.H., Brosnahan, M.L., Kulis, D.M., Anderson, D.M., Plumley, F.G. Independent evolution of saxitoxin synthesis in cyanobacteria and dinoflagellates. Mol. Biol. Evol., in press.

Halim, Y., 1960. Alexandrium minutum nov. g. nov. sp. dinoflagellé provocant des 'eaux rouges' Vie Milieu 11, 102-105.

Hall, S., 1982. Toxins and toxicity of Protogonyaulax from the Northeast Pacific. Ph.D. dissertation. University of Alaska, $196 \mathrm{pp}$.

Hallegraeff, G.M., 1993. A review of harmful algal blooms and their apparent global increase. Phycologia 32, 79-99.

Hallegraeff, G.M., Marshall, J.A., Valentine, J., Hardiman, S., 1998. Short cyst-dormancy period of an Australian isolate of the toxic dinoflagellate Alexandrium catenella. Mar. Freshwater Res. 49, 415-420.

Hamasaki, K., Horie, M., Tokimitsu, S., Toda, T., Taguchi, S., 2001. Variability in toxicity of the dinoflagellate Alexandrium tamarense isolated from Hiroshima Bay, Western Japan, as a reflection of changing environmental conditions. J. Plankton Res. 23, 271-278.

Han, M.S., Jeon, J.K., Kim, Y.O., 1992. Occurrence of dinoflagellate Alexandrium tamarense, a causative organism of paralytic shellfish poisoning in Chinae Bay, Korea. J. Plankton Res. 14, 1581-1592.

Hansen, P.J., 1989. The red tide dinoflagellate Alexandrium tamarense: effects on behaviour and growth of a tintinnid ciliate. Mar. Ecol. Prog. Ser. 53, 105-116.

Hansen, P.J., Cembella, A.D., Moestrup, O., 1992. The marine dinoflagellate Alexandrium ostenfeldii: Paralytic shellfish concentration, composition, and toxicity to a tintinnid ciliate. J. Phycol. 28, 597-603.

Hansen, G., Daugbjerg, N., Franco, J.M., 2003. Morphology, toxin composition and LSU rDNA phylogeny of Alexandrium minutum (Dinophyceae) from Denmark, with some morphological observations on other European strains. Harmful Algae 2, 317-335

He, H., Chen, F., Li, H., Xiang, W., Li, Y., Jiang, Y., 2010. Effect of iron on growth, biochemical composition and paralytic shellfish poisoning toxins production of Alexandrium tamarense. Harmful Algae 9, 98-104.

He, R., McGillicuddy, D.J., Keafer, B.A., Anderson, D.M., 2008. Historic 2005 toxic bloom of Alexandrium fundyense in the western Gulf of Maine: 2. Coupled biophysical numerical modeling. J. Geophys. Res. - Oceans 113, C07040, doi:10.1029/2007JC004602.

Heisler, J., Glibert, P.M., Burkholder, J.M., Anderson, D.M., Cochlan, W., Dennison, W.C., Dortch, Q., Gobler, C.J., Heil, C.A., Humphries, E., Lewitus, A., Magnien, R., Marshall, H.G., Sellner, K., Stockwell, D.A., Stoecker, D.K., Suddleson, M., 2008. Eutrophication and harmful algal blooms: a scientific consensus. Harmful Algae 8, 3-13.

Hong, D.D., Hien, H.T.M., Thu, N.H., Anh, H.L., Luyen, Q.H., 2008. Phylogenetic analyses of Prorocentrum spp. and Alexandrium spp. isolated from Northern coast of Vietnam based on 18S rDNA sequence. J. Environ. Biol. 29, 535-542.
Howell, J.F., 1953. Gonyaulax monilata, sp. nov., the causative dinoflagellate of a red tide on the east coast of Florida in August-September, 1951. Trans. Am. Microsc. Soc. 72, 153-156.

Hsia, M.H., Morton, S.L., Smith, L.L., Beauchesne, K.R., Huncik, K.M., Moeller, P.D.R., 2005. Production of goniodomin A by the planktonic, chain-forming dinoflagellate Alexandrium monilatum (Howell) Balech isolated from the Gulf Coast of the United States. Harmful Algae 5, 290-299.

Imai, I., Yamaguchi, M., Hori, Y., 2006. Eutrophication and occurrences of harmful algal blooms in the Seto Inland Sea, Japan. Plankton Benthos Res. 1, 71-84.

Ishida, Y., Uchida, A., Sako, Y., 1998. Genetic and biochemical approaches to PSP toxin production of toxic dinoflagellates. In: Anderson, D.M., Cembella, A.D., Hallegraeff, G.M.(Eds.),Physiological Ecology of Harmful Algal Blooms. Springer, Berlin, Heidelberg, New York, pp. 49-58.

Ishikawa, A., Hattori, M., Imai, I., 2007. Development of the "plankton emergence trap/chamber (PET Chamber)", a new sampling device to collect in situ germinating cells from cysts of microalgae in surface sediments of coastal waters. Harmful Algae 6, 301-307.

Itakura, S., Yamaguchi, M., 2001. Germination characteristics of naturally occurring cysts of Alexandrium tamarense (Dinophyceae) in Hiroshima Bay, Inland Sea of Japan. Phycologia 40, 263-267.

Jacobson, D.M., Anderson, D.M., 1996. Widespread phagocytosis of ciliates and other protists by marine mixotrophic and heterotrophic thecate dinoflagellates. J. Phycol. 32, 279-285.

Jaeckisch, N., Singh, R., Curtis, B., Cembella, A., John, U., 2008. Genomic characterization of the spirolide-producing dinoflagellate Alexandrium ostenfeldii with special emphasis on PKS genes. In: Moestrup, O., et al. (Eds.), Proceedings of the 12th International Conference on Harmful Algae. International Society for the Study of Harmful Algae and Intergovernmental Oceanographic Commission of UNESCO, Copenhagen, pp. 65-67.

Jauzein, C., Collos, Y. Garcés, E., Vila, M., Maso, M., 2008a. Short-term temporal variability of ammonium and urea uptake by Alexandrium catenella (Dinophyta) in cultures. J. Phycol. 44, 1136-1145.

Jauzein, C., Labry, C., Youenou, A., Quéré, J., Delmas, D., Collos, Y., 2010. Growth and phosphorus uptake by the toxic dinoflagellate Alexandrium catenella (Dinophyceae) in response to phosphate limitation. J. Phycol. 46, 926-936.

Jauzein, C., Loureiro, S., Garcés, E., Collos, Y., 2008b. Interactions between ammonium and urea uptake by 5 strains of Alexandrium catenella (Dinophyta) in cultures. Aquat. Microb. Ecol. 53, 271-280.

Jeong, H.J., Yoo, Y.D., Kim, J.S., Kim, T.H., Kim, J.H., Kang, N.S., Yih, W.H., 2004. Mixotrophy in the phototrophic harmful alga Cochlodinium polykrikoides (dinophycean): prey species, the effects of prey concentration, and grazing impact. J. Eukaryot. Microbiol. 51, 563-569.

Jeong, H.J., Yoo, Y.D., Kim, J.S., Seong, K.A., Kang, N.S., Kim, T.H., 2010. Growth, feeding and ecological roles of the mixotrophic and heterotrophic dinoflagellates in marine planktonic food webs. Ocean Sci. J. 45, 65-91.

John, E.H., Flynn, K.J., 1999. Amino acid uptake by the toxic dinoflagellate Alexan drium fundyense. Mar. Biol. 133, 11-19.

John, E.H., Flynn, K.J., 2002. Modelling changes in paralytic shellfish toxin content of dinoflagellates in response to nitrogen and phosphorus supply. Mar. Ecol. Prog. Ser. 225, 147-160.

John, U., Cembella, A., Hummert, C., Elbrächter, M., Groben, R., Medlin, L.K., 2003a. Discrimination of the toxigenic dinoflagellates Alexandrium tamarense and $A$. ostenfeldii in co-occurring natural populations from Scottish coastal waters. Eur. J. Phycol. 38, 25-40.

John, U., Fensome, R.A., Medlin, L.K., 2003b. The application of a molecular clock based on molecular sequences and the fossil record to explain biogeographic distributions within the Alexandrium tamarense "species complex" (Dinophyceae). Mol. Biol. Evol. 20, 1015-1027.

John, U., Medlin, L.K., Groben, R., 2005. Development of specific rRNA probes to distinguish between geographic clades of the Alexandrium tamarense species complex. J. Plankton Res. 27, 199-204.

John, U., Quilliam, M.A., Medlin, L., Cembella, A.D., 2001. Spirolide production and photoperiod-dependent growth of the marine dinoflagellate Alexandrium ostenfeldii. In: Hallegraeff, G.M., Blackburn, S.I., Bolch, C.J., Lewis, R.J. (Eds.), Harmful Algal Blooms 2000. Intergovernmental Oceanographic Commission of UNESCO, pp. 299-302.

Katoh, M., Kuma, M., 2002. MAFFT: a novel method for rapid multiple sequence alignment based on fast Fourier transform. Nucleic Acids Res. 30, 3059-3066.

Kellmann, R., Mihali, T.K., Jeon, Y.J., Pickford, R., Pomati, F., Neilan, B.A., 2008. Biosynthetic intermediate analysis and functional homology reveal a saxitoxin gene cluster in cyanobacteria. Appl. Environ. Microbiol. 74, 4044-4053.

Kim, K.Y., Yoshida, M., Kim, C.H., 2005. Molecular phylogeny of three hitherto unreported Alexandrium species: Alexandrium hiranoi, Alexandrium leei and Alexandrium satoanum (Gonyaulacales, Dinophyceae) inferred from the $18 \mathrm{~S}$ and 26S rDNA sequence data. Phycologia 44, 361-368.

Kita, T., Fukuyo, Y., 1988. Description of the gonyaulacoid dinoflagellate Alexandrium hiranoi sp. nov. inhabiting tidepools on Japanese Pacific coast. Bull. Plankton Soc. Jpn. 35, 1-7.

Kita, T., Fukuyo, Y., Tokuda, H., Hirano, R., 1985. Life history and ecology of Goniodoma pseudogonyaulax (Pyrrhophyta) in a rockpool. Bull. Mar. Sci. 37, 643-651.

Kita, T., Fukuyo, Y., Tokuda, H., Hirano, R., 1993. Sexual reproduction of Alexandrium hiranoi (Dinophyceae). Bull. Plankton Soc. Jpn. 39, 79-85.

Kremp, A., Lindholm, T., Dreler, N., Erler, K., Gerdts, G., Eirtovaara, S., Leskinen, E., 2009. Bloom forming Alexandrium ostenfeldii (Dinophyceae) in shallow water of the Finland Archipelago, Northern Baltic Sea. Harmful Algae 8, 318-328. 
Kudela, R.M., Seeyave, S., Cochlan, W.P., 2010. The role of nutrients in regulation and promotion of harmful algal blooms in upwelling systems. Prog. Oceanogr. 85 $122-135$.

Labry, C., Erard-Le Denn, E., Chapelle, A., Fauchot, J., Youenou, A., Crassous, M.P., Le Grand, J., Lorgeoux, B., 2008. Competition for phosphorus between two dinoflagellates: a toxic Alexandrium minutum and a non-toxic Heterocapsa triquetra. J. Exp. Mar. Biol. Ecol. 358, 124-135.

Langdon, C., 1987. On the causes of interspecific differences in the growth-irradiance relationship for phytoplankton. I. A comparative study of the growthirradiance relationship of three marine phytoplankton species: Skeletonema costatum, Olisthodiscus luteus and Gonyaulax tamarensis. J. Plankton Res. 9, 459 482 .

Larsen, J., Nguyen-Ngoc, L., 2004. Potentially Toxic Macroalgae of Vietnamese Waters, vol. 140. Opera Botanica, Copenhagen, p. 216.

Leaw, C.P., Lim, P.T., Ng, B.K., Cheah, M.Y., Ahmad, A., Usup, G., 2005. Phylogenetic analysis of Alexandrium species and Pyrodinium bahamense (Dinophyceae) based on theca morphology and nuclear ribosomal gene sequence. Phycologia 44, 550-565

Lebour, M.V., 1925. The Dinoflagellates of the Northern Seas. Plymouth Marine Biology Association, pp. 1-250.

Legrand, C., Carlsson, P., 1998. Uptake of high molecular weight dextran by the dinoflagellate Alexandrium catenella. Aquat. Microb. Ecol. 16, 81-86.

Leong, S.C.Y., Maekawa, M., Taguchi, S., 2010. Carbon and nitrogen acquisition by the toxic dinoflagellate Alexandrium tamarense in response to different nitrogen sources and supply modes. Harmful Algae 9, 48-58.

Levasseur, M., Gamache, T., St.-Pierre, I., Michaud, S., 1995. Does the cost of NO reduction affect the production of harmful compounds by Alexandrium excavatum. In: Arzul, G., Erard, E., Gentien, P., Marcaillou, C. (Eds.), Harmful Marine Algal Blooms. Lavoisier, Intercept Ltd., Paris, pp. 463-468.

Lewis, J., Higman, W., Kuenstner, S., 1995. Occurrence of Alexandrium sp. cysts in sediments from the North East coast of Britain. In: Lassus, P., Arzul, G., Erard, E., Gentien, P., Marcaillou, C. (Eds.), Harmful Marine Algal Blooms. Lavoiser Science Publishers, Paris, pp. 175-180.

Li, Y., He, R., McGillicuddy Jr., D.J., Anderson, D.M., Keafer, B.A., 2009. Investigation of the 2006 Alexandrium fundyense bloom in the Gulf of Maine: In situ observations and numerical modeling. Cont. Shelf Res. 29 (17), 2069-2082.

Lilly, E.L. 2003. Phylogeny and Biogeography of the Toxic Dinoflagellate Alexandrium. Ph.D. Thesis. Massachusetts Institute of Technology/Woods Hole Oceanographic Institution, 226 pp.

Lilly, E.L., Halanych, K.M., Anderson, D.M., 2005. Phylogeny biogeography and species boundaries within the Alexandrium minutum group. Harmful Algae 4 1004-1020.

Lilly, E.L., Halanych, K.M., Anderson, D.M., 2007. Species boundaries and global biogeography of the Alexandrium tamarense complex (Dinophyceae). J. Phycol. 43, 1329-1338.

Lilly, E.L., Kulis, D.M., Gentien, P., Anderson, D.M., 2002. Paralytic shellfish poisoning toxins in France linked to a human-introduced strain of Alexandrium catenella from the western Pacific: Evidence from DNA and toxin analysis. J. Plankton Res. $24,443-452$

Lim, P.T., Leaw, C.P., Ogata, T., 2007. Morphological variation of two Alexandrium species responsible for paralytic shellfish poisoning in Southeast Asia. Bot. Mar. $50,14-21$.

Lin, S., Zhang, H., Hou, Y., Zhuang, Y., Miranda, L., 2009. High-level diversity of dinoflagellates in the natural environment, revealed by assessment of mitochondrial cox1 and cob genes for dinoflagellate DNA barcoding. Appl. Environ. Microbiol. 75, 1279-1290.

Lin, S., Zhanga, H., Zhuanga, Y., Tranb, B., Gill, J., 2010. Spliced leader-based metatranscriptomic analyses lead to recognition of hidden genomic features in dinoflagellates. Proc. Natl. Acad. Sci. U.S.A. 46, 20033-20038.

Llaveria, G., Garcés, E., Ross, O.N., Figueroa, R.I., Sampedro, N., Berdalet, E., 2010. Significance of small-scale turbulence for parasite infectivity of dinoflagellates. Mar. Ecol. Prog. Ser. 412, 45-56.

Loureiro, S., Garcés, E., Collos, Y., Vaqué, D., Camp, J., 2009. Effect of marine autotrophic dissolved organic matter (DOM) on Alexandrium catenella in semi-continuous cultures. J. Plankton Res. 31, 1363-1372.

Lugliè, A., Giacobbe, M.G., Sannio, A., Fiocca, F., Sechi, N., 2003. First record of the dinoflagellate Alexandrium catenella (Whedon \& Kofoid) Balech (Dinophyta), a potential producer of paralytic shellfish poisoning, in Italian waters (Sardinia, Tyrrhenian Sea). Bocconea 16, 1045-1052.

Lush, G., Negri, A.P., Hallegraeff, G.M., 2001. Production of exotoxins by Alexandrium minutum. In: Hallegraeff, G.M., Blackburn, S.I., Bolch, C.J.S., Lewis, R (Eds.), Harmful Algal Blooms 2000. Intergovernmental Oceanographic Commission of UNESCO, pp. 268-271.

Ma, H., Krock, B., Tillmann, U., Bickmeyer, U., Graeve, M., Cembella, A., 2011. Mode of action of membrane-disruptive lytic compounds from the marine dinoflagellate Alexandrium tamarense. Toxicon 58, 247-258.

Ma, H., Krock, B., Tillmann, U., Cembella, A., 2009. Preliminary characterization of extracellular allelochemicals of the toxic marine dinoflagellate Alexandrium tamarense using a Rhodomonas salina bioassay. Mar. Drugs 7, 497-522.

MacIntyre, J.G., Cullen, J.J., Cembella, A.D., 1997. Vertical migration, nutrition, and toxicity in the dinoflagellate Alexandrium tamarense. Mar. Ecol. Prog. Ser. 148 201-216.

MacIsaac, J.J., Grunseich, G.S., Glover, H.E., Yentsch, C.M., 1979. Light and nutrient limitation in Gonyaulax excavata: nitrogen and carbon trace results. In: Taylor, D.L., Seliger, H.H. (Eds.), Toxic Dinoflagellate Blooms. Elsevier, North Holland, New York, pp. 107-110.
MacKenzie, L., Todd, K., 2002. Alexandrium camurascutulum sp. nov. (Dinophyceae): a new dinoflagellate species from New Zealand. Harmful Algae 1, 295-300.

MacKenzie, L., de Salas, M., Adamson, J., Beuzenberg, V., 2004. The dinoflagellate genus Alexandrium (Halim) in New Zealand coastal waters: comparative morphology, toxicity and molecular genetics. Harmful Algae 3, 71-92.

MacKenzie, L., White, D., Oshima, Y., Kapa, J., 1996. The resting cyst and toxicity of Alexandrium ostenfeldii (Dinophyceae) in New Zealand. Phycologia 35 (2), 148155.

MacKinnon, S.L., Cembella, A.D., Burton, I.W., Lewis, N.I., LeBlanc, P., Walter, J.A. 2006. Biosynthesis of 13-desmethyl spriolide $C$ by dinoflagellate Alexandrium ostenfeldii. J. Org. Chem. 71, 8724-8731.

Maguer, J.F., L'Helguen, S., Madec, C., Labry, C., Le Corre, P., 2007. Nitrogen uptake and assimilation kinetics in Alexandrium minutum (Dinophyceae): effect of $\mathrm{N}$ limited growth rate on nitrate and ammonium interactions. J. Phycol. 43, 295303.

Margalef, R., Estrada, M., 1987. Synoptic distribution of summer microplankton (algae and protozoa) across the principal front in the Western Mediterranean. Invest. Pesqueria 51, 121-140.

Marret, F., Zonneveld, K.A.F., 2003. Atlas of modern organic-walled dinoflagellate cyst distribution. Rev. Palaeobot. Palynol. 125, 1-200.

Maso, M., Garcés, E., 2006. Harmful microalgae blooms (HAB); problematic and conditions that induce them. Mar. Pollut. Bull. 53, 620-630.

Masseret, E., Grzebyk, D., Nagai, S., Genovesi, B., Lasserre, B., Laabir, M., Collos, Y. Vaquer, A., Berrebi, P., 2009. Unexpected genetic diversity among and within populations of the toxic dinoflagellate Alexandrium catenella as revealed by nuclear microsatellite markers. Appl. Environ. Microbiol. 75, 2037-2045.

Matrai, P., Thompson, B., Keller, M., 2005. Circannual excystment of resting cysts of Alexandrium spp. from eastern Gulf of Maine populations. Deep-Sea Res. Pt. II 52, 2560-2568.

Matsuda, A., Nishijima, T., Fukami, K., 1999. Effects of nitrogenous and phosphorus nutrients on the growth of toxic dinoflagellate Alexandrium catenella. Nippon Suisan Gakk. 65, 847-855.

Matsuoka, K., Fukuyo, Y., 2003. Taxonomy of cysts. In: Hallegraeff, G.M., Anderson, D.M., Cembella, A.D. (Eds.), Manual on Harmful Marine Microalgae. UNESCO, Paris, pp. 563-592.

McCauley, L.A.R., Erdner, D.L., Nagai, S., Richlen, M.L., Anderson, D.M., 2009. Biogeographic analysis of the globally distributed harmful algal bloom species Alexandrium minutum (Dinophyceae) based on rRNA gene sequences and microsatellite markers. J. Phycol. 45, 454-463.

McGillicuddy Jr., D.J., Anderson, D.M., Lynch, D.R., Townsend, D.W., 2005. Mechanisms regulating large-scale seasonal fluctuations in Alexandrium fundyense populations in the Gulf of Maine: Results from a physical-biological model. Deep-Sea Res. Pt. II 52 (19-21), 2698-2714.

McGillicuddy Jr., D.J., Townsend, D.W., He, R., Keafer, B.A., Kleindinst, J.L., Li, Y., Manning, J., Mountain, D., Thomas, A., Anderson, D.M., 2011. Suppression of the 2010 Alexandrium fundyense bloom by changes in physical, biological, and chemical properties of the Gulf of Maine. Limnol. Oceanogr. 56 (6), 2411-2426.

Menezes, M., Varela, D., de Oliveira Troenç, L.A., da Silva Tamanaha, M., Paredes, J., 2010. Identification of the toxic algae Alexandrium tamiyavanichi (Dinophyceae) from Northeastern Brazil: a combined morphological and rDNA sequence (partial LSU and ITS) approach. J. Phycol. 46, 1239-1251.

Metfies, K., Huljic, S., Lange, M., Medlin, L.K., 2005. Electrochemical detection of the toxic dinoflagellate Alexandrium ostenfeldii with a DNA-biosensor. Biosens. Bioelectron. 20, 1349-1357.

Miller, P.E., Scholin, C.A., 1998. Identification and enumeration of cultured and wild Pseudo-nitzschia (Bacillariophyceae) using species-specific LSU rRNA-targeted fluorescent probes and filter-based whole cell hybridization. J. Phycol. 34, 371382.

Moestrup, Ø., Akselman, R., Cronberg, G., Elbraechter, M., Fraga, S., Halim, Y., Hansen, G., Hoppenrath, M., Larsen, J., Lundholm, N., Nguyen, L.N., Zingone, A., 2011. IOC-UNESCO Taxonomic Reference List of Harmful Micro Algae. http:// www.marinespecies.org/hab/aphia.php? $\mathrm{p}=$ taxdetails\&id=156548.

Monroe, E.A., Van Dolah, F.M., 2008. The toxic dinoflagellate Karenia brevis encodes novel type I-like polyketide synthases containing discrete catalytic domains. Protist 159, 471-482.

Montagnes, D.J.S., Chambouvet, A., Guillou, L., Fenton, A., 2008. Can microzooplankton and parasite pressure be responsible for the demise of toxic dinoflagellate blooms? Aquat. Microb. Ecol. 53, 211-225.

Montresor, M., 1995. The life history of Alexandrium pseudogonyaulax (Gonyaulacales, Dinophyceae). Phycologia 34, 444-448.

Montresor, M., Marino, D., 1996. Modulating effect of cold-dark storage on excystment in Alexandrium pseudogonyaulax (Dinophyceae). Mar. Biol. 127, 55-60.

Montresor, M., John, U., Beran, A., Medlin, L.K., 2004. Alexandrium tamutum sp. nov. (Dinophyceae): a new nontoxic species in the genus Alexandrium. J. Phycol. 40, 398-411.

Nagai, S., 2011. Development of a multipluex PCR assay for simultaneous detection of six Alexandrium species (Dinophyceae). J. Phycol. 47, 703-708.

Nagai, S., Lian, C., Hamaguchi, M., Matsuyama, Y., Itakaru, S., Hogetsu, T., 2004. Development of microsatellite markers in the toxic dinoflagellate Alexandrium tamarense (Dinophyceae). Mol. Ecol. Notes 4, 83-85.

Nagai, S., McCauley, L., Yasuda, N., Erdner, D.L., Kulis, D.M., Matsuyama, Y., Itakura, S., Anderson, D.M., 2006a. Development of microsatellite markers in the toxic dinoflagellate Alexandrium minutum (Dinophyceae). Mol. Ecol. Notes 6, 756-758.

Nagai, S., Sekino, M., Matsuyama, Y., Itakura, S., 2006b. Development of microsatellite markers in the toxic dinoflagellate Alexandrium catenella (Dinophyceae). Mol. Ecol. Notes 6, 120-122. 
Nagai, S., Lian, C., Yamaguchi, S., Hamaguchi, M., Matsuyama, Y., Itakura, S., Shimada, H., Kaga, S., Yamauchi, H., Sonda, Y., Nishikawa, T., Kim, C.-H., Hogetsu, T., 2007. Microsatellite markers reveal population genetic structure of the toxic dinoflagellate Alexandrium tamarense (Dinophyceae) in Japanese coastal waters. J. Phycol. 43, 43-54.

Ni Rathaille, A., Raine, R. Seasonality in the excystment of Alexandrium minutum and Alexandrium tamarense in Irish coastal waters. Harmful Algae, in press.

Nishitani, L., Hood, R., Wakeman, J., Chew, K.K., 1984. Potential importance of an endoparasite of Gonyaulax in Paralytic Shellfish Poisoning outbreaks. In: Ragelis, E. (Ed.), Seafood Toxins. Amer. Chem. Soc. Symposium Series, Washington, DC, pp. $139-150$.

Oh, S.J., Yamamoto, T., Kataoka, Y., Matsuda, O., Matsuyama, Y., Kotani, Y., 2002. Utilization of dissolved organic phosphorus by the two toxic dinoflagellates. Alexandrium tamarense and Gymnodinium catenatum (Dinophyceae). Fisheries Sci. $68,416-424$.

Olli, K., Neubert, M.G., Anderson, D.M., 2004. Encystment probability and encystment rate: new terms to quantitatively describe formation of resting cysts in planktonic microbial populations. Mar. Ecol. Prog. Ser. 273, 43-48.

Ou, L.J., Huang, B.Q., Lin, L.Z., Hong, H.S., Zhang, F., Chen, Z.Z., 2006. Phosphorus stress of phytoplankton in the Taiwan Strait determined by bulk and single-cell alkaline phosphatase activity assays. Mar. Ecol. Prog. Ser. 327, 95-106.

Ou, L., Wang, D., Huang, B., Hong, H., Qi, Y., Lu, S., 2008. Comparative study of phosphorus strategies of three typical harmful algae in Chinese coastal waters. J. Plankton Res. 30, 1007-1017.

Paulsen, O., 1904. Plankton investigation in the waters round Iceland in 1903. Medd. Komm. Havunders. Kopenhaven, Ser. Plankton 1, 1-40.

Penna, A., Magnani, M., 1999. Identification of Alexandrium spp. (Dinophyceae) species using PCR and rDNA-targeted probes. J. Phycol. 35, 615-621.

Penna, A., Fraga, S., Masó, M., Giacobbe, M.G., Bravo, I., Garcés, E., Vila, M., Bertozzini, E., Andreoni, F., Luglié, A., Vernesi, C., 2008. Phylogenetic relationships among the Mediterranean Alexandrium (Dinophyceae) species based on sequences of $5.8 \mathrm{~S}$ gene and Internal Transcript Spacers of the rRNA operon. Eur. J. Phycol. 43, $163-178$.

Penna, A., Bertozzini, E., Battocchi, C., Galluzzi, L., Giacobbe, M.G., Vila, M., Garcés, E. Luglie, A., Magnani, M., 2007. Monitoring of HAB species in the Mediterranean Sea through molecular methods. J. Plankton Res. 29, 19-38.

Posada, D., 2008. jModelTest: phylogenetic model averaging. Mol. Biol. Evol. 25, $1253-1256$.

Prakash, A., 1967. Growth and toxicity of a marine dinoflagellate. Gonyaulax tamarensis. J. Fish Res. Board Can. 24, 1589.

Prakash, A., Rashid, M.A., 1968. Influence of humic substances on the growth of marine phytoplankton: dinoflagellates. Limnol. Oceanogr. 13, 598-606.

Prakash, A., Medcof, J.C., Tennant, A.D., 1971. Paralytic shellfish poisoning in eastern Canada. B. Fish. Res. Board Can. 177, 1-87.

Probert, I., Lewis, J., Erard-Le Denn, E., 2002. Morphological details of the life history of Alexandrium minutum (Dinophyceae). Cryptogam. Algol. 23, 343-355.

Proctor, N.H., Chan, S.L., Trevor, A.J., 1975. Production of saxitoxin by cultures of Gonyaulax catenella. Toxicon 13, 1-9.

Raven, J.R., Richardson, K., 1984. Dinoflagellate flagella: a cost-benefit analysis. New Phytol. 98, 259-276.

Rogers, J.E., Leblond, J.D., Moncreiff, C.A., 2006. Phylogenetic relationship of Alexandrium monilatum (Dinophyceae) to other Alexandrium species based on $18 \mathrm{~S}$ ribosomal RNA gene sequences. Harmful Algae 5, 275-280.

Ruiz Sebastián, C., Etheridge, S.M., Cook, P.A., O’Ryan, C., Pitcher, G.C., 2005 Phylogenetic analysis of toxic Alexandrium (Dinophyceae) isolates from South Africa: implications for the global phylogeography of the Alexandrium tamarense species complex. Phycologia 44, 49-60.

Sako, Y., Kim, C.H., Ishida, Y., 1992. Mendelian inheritance of paralytic shellfish poisoning toxin in the marine dinoflagellate Alexandrium catenella. Biosci. Biotechnol. Biochem. 56, 692-694.

Sako, Y., Hosoi-Tanabe, S., Uchida, A., 2004. Fluorescence in situ hybridization using rRNA-targeted probes for simple and rapid identification of the toxic dinoflagellates Alexandrium tamarense and Alexandrium catenella. J. Phycol. 40, 598-605.

Salomon, P.S., Imai, I., 2006. Pathogens of harmful microalgae. In: Granéli, E., Turner, J.T. (Eds.), Ecology of Harmful Algae. Springer, Heidelberg, pp. 271-282.

Saldarriaga, J.F., Taylor, F., Cavalier-Smith, T., Menden-Deuer, S., Keeling, P., 2004. Molecular data and the evolutionary history of dinoflagellates. Eur. J. Protistol. $40,85-111$.

Sawayama, S., Sako, Y., Ishida, Y., 1993. Inhibitory effects of concanavalin a and tunicamycin on sexual attachment of Alexandrium catenella (Dinophyceae). J. Phycol. 29, 189-190.

Schantz, E.J., Lynch, J.M., Vayvada, G., Matsumoto, K., Rapoport, H., 1966. The purification and characterization of the poison produced by Gonyaulax catenella in axenic culture. Biochemistry 5, 1191-1195.

Scholin, C.A., Anderson, D.M., 1994. Identification of group- and strain-specific genetic markers for globally distributed Alexandrium (Dinophyceae). I. RFLP analysis of SSU rDNA genes. J. Phycol. 30, 744-754.

Scholin, C.A., Anderson, D.M., 1996. LSU rDNA-based RFLP Assays for discriminating species and strains of Alexandrium (Dinophyceae). J. Phycol. 32, 1022-1035.

Scholin, C.A., Hallegraeff, G.M., Anderson, D.M., 1995. Molecular evolution of the Alexandrium tamarense species complex (Dinophyceae): dispersal in the North American and West Pacific regions. Phycologia 34, 472-485.

Scholin, C.A., Herzog, M., Sogin, M., Anderson, D.M., 1994. Identification of groupand strain-specific genetic markers for globally distributed Alexandrium (Dinophyceae). 2. Sequence analysis of a fragment of the LSU rRNA gene. J. Phycol. 30, 999-1011.
Scholin, C., Doucette, G., Jensen, S., Roman, B., Pargett, D., Marin III, R., Preston, C., Jones, W., Feldman, J., Everlove, C., Harris, A., Avarado, N., Massion, E., Birch, J. Greenfield, D., Wheeler, K., Vrijenhoek, R., Mikulski, C., Jones, K., 2009. Remote detection of marine microbes, small invertebrates, harmful algae and biotoxins using the Environmental Sample Processor (ESP). Oceanography 22, 158-167.

Selander, E., Jakobsen, H.H., Lombard, F., Kiørboe, T., 2011. Grazer cues induce stealth behavior in marine dinoflagellates. Proc. Natl. Acad. Sci. U.S.A. 108 (10), 4030-4034.

Selander, E., Thor, P., Toth, G., Pavia, H., 2006. Copepods induce paralytic shellfish toxin production in marine dinoflagellates. Proc. R. Soc. B 273, 1673-1680.

Shimizu, Y., 1996. Microalgal metabolites: a new perspective. Annu. Rev. Microbiol. $50,431-465$

Siu, G., Young, M., Chan, D., 1997. Environmental and nutritional factors which regulate population dynamics and toxin production in the dinoflagellate Alexandrium catenella. Hydrobiologia 352, 117-140.

Smayda, T.J., 1996. Dinoflagellate bloom cycles: what is the role of cellular growth rate and bacteria? In: Yasumoto, T., Oshima, Y., Fukuyo, Y. (Eds.), Harmful and Toxic Algal Blooms. Intergovernmental Oceanographic Commission of UNESCO pp. 331-334.

Smayda, T.J., 2007. Reflections on the ballast water dispersal - harmful algal bloom paradigm. Harmful Algae 6, 601-622.

Smayda, T.J., 2008. Complexity in the eutrophication-harmful algal bloom relationship, with comment on the importance of grazing. Harmful Algae 8, 140-151.

Smetacek, V., 2001. A watery arms race. Nature 411, 745.

Sorokin, Y.I., Sorokin, P.Y., Ravagnan, G., 1996. On an extremely dense bloom of the dinoflagellate Alexandrium tamarense in lagoons of the PO river delta: Impact on the environment. J. Sea Res. 35, 251-255.

Soto-Liebe, K., Murillo, A.A., Krock, B., Stucken, K., Fuentes-Valdés, J.J., Trefault, N., Cembella, A.D., Vásquez, M., 2010. Reassessment of the toxin profile of Cylindrospermopsis raciborskii $\mathrm{T} 3$ and function of putative sulfotransferases in synthesis of sulfated and sulfonated PSP toxins. Toxicon 56, 1350-1361.

Spalter, R.A., Walsh, D., Reeves, R.A., Saul, D.J., Gray, R.D., Bergquist, P.L., MacKenzie L., Bergquist, P.R., 1997. Sequence heterogeneity of the ribosomal RNA intergenic region Alexandrium species. Biochem. Syst. Ecol. 25, 231-233.

Spatharis, S., Danielidis, D.S., Tsirtsis, G., 2007. Recurrent Pseudo-nitzschia calliantha (Bacillariophyceae) and Alexandrium insuetum (Dinophyceae) winter blooms induced by agricultural runoff. Harmful Algae 6, 811-822.

Steidinger, K.A., 1971. Gonyaulax balechii sp. nov. (Dinophyceae) with a discussion of the genera Gonyaulax and Heteraulacus. Phycologia 10, 183-187.

Stern, R.F., Horak, A., Andrew, R.L., Coffroth, M.-A., Andersen, R.A., Küpper, F.C., Jameson, I., Hoppenrath, M., Véron, B., Kasai, F., Brand, J., James, E.R., Keeling, P.J. 2010. Environmental barcoding reveals massive dinoflagellate diversity in marine environments. PloS One 5, e13991.

Stock, C.A., McGillicuddy, D.J., Solow, A.R., Anderson, D.M., 2005. Evaluating hypotheses for the initiation and development of Alexandrium fundyense blooms in the western Gulf of Maine using a coupled physical-biological model. Deep-Sea Res. Pt. II 52 (19-21), 2715-2744.

Stolte, W., Panosso, R., Gisselson, L.-A., Granéli, E., 2002. Utilization efficiency of nitrogen associated with riverine dissolved organic carbon ( $>1 \mathrm{kDa}$ ) by two toxin-producing phytoplankton species. Aquat. Microb. Ecol. 29, 97-105.

Stüken, A., Orr, R.J.S., Kellmann, R., Murray, S.A., Neilan, B.A., Jakobsen, K.S., 2011. Discovery of nuclear-encoded genes for the neurotoxin saxitoxin in dinoflagellates. PLoS One 6 (5), doi:10.1371/journal.pone.0020096.

Sullivan, J.M., Swift, E., Donaghay, P.L., Rines, J.E.B., 2003. Small-scale turbulence affects the division rate and morphology of two red-tide dinoflagellates. Harmful Algae 2 (3), 183-199.

Takeuchi, T., Kokubo, T., Fukuyo, Y., Matsuoka, K., 1995. Quantitative relationship among vegetative cells, planozygotes, and hypnozygotes of Alexandrium catenella (Dinophyceae) in its blooming season at Tanabe Bay, Central Japan. In: Abstract, 7th Int'l. Conf. on Toxic Phytoplankton, Sendai, Japan.

Tang, Y.Z., Koch, F., Gobler, C.J., 2010. Most harmful algal bloom species are vitamin B-1 and B-12 auxotrophs. Proc. Natl. Acad. Sci. U.S.A. 107, 20756-20761.

Taroncher-Oldenburg, G., Anderson, D.M., 2000. Identification and characterization of three differentially expressed genes, encoding S-adenosylhomocysteine hydrolase, methionine aminopeptidase, and a histone-like protein, in the toxic dinoflagellate Alexandrium fundyense. Appl. Environ. Microbiol. 66, 2105-2112.

Taroncher-Oldenburg, G., Kulis, D.M., Anderson, D.M., 1997. Toxin variability during the cell cycle of the dinoflagellate Alexandrium fundyense. Limnol. Oceanogr. 42, 1178-1188.

Taylor, F.J.R., Fukuyo, Y., Larsen, J., 1995. Taxonomy of harmful dinoflagellates. In: Hallegraeff, G.M., Anderson, D.M., Cembella, A.D. (Eds.), Manual on Harmfu Marine Microalgae. IOC Manuals and Guides No. 33. UNESCO, Paris, pp. 283-317.

Therriault, J.C., Painchaud, J., Levasseur, M., 1985. Factors controlling the occurrence of Protogonyaulax tamarensis and shellfish toxicity in the St. Lawrence Estuary: freshwater runoff and the stability of the water column. In: Anderson, D.M. White, A.W., Baden, D.G. (Eds.), Toxic Dinoflagellates. Elsevier Science, New York, pp. 141-146.

Thoresen, S.S., Dortch, Q., Ahmed, S.I., 1982. Comparisons of methods for extracting intracellular pools of inorganic nitrogen from marine phytoplankton. J. Plankton Res. 4, 495-704.

Tillmann, U., John, U., 2002. Toxic effects of Alexandrium spp. on heterotrophic dinoflagellates: an allelochemical defence mechanism independent of PSPtoxin content. Mar. Ecol. Prog. Ser. 230, 47-58.

Tillmann, U., Alpermann, T.L., da Purificaçao, R.C., Krock, B., Cembella, A., 2009. Intra-population clonal variability in allelochemical potency of the toxigenic dinoflagellate Alexandrium tamarense. Harmful Algae 8, 759-769. 
Tillmann, U., John, U., Cembella, A.D., 2007. On the allelochemical potency of the marine dinoflagellate Alexandrium ostenfeldii against heterotrophic and autotrophic protists. J. Plankton Res. 29, 527-543.

Toth, G.B., Norén, N., Selander, E., Pavia, H., 2004. Marine dinoflagellates show induced life-history shifts to escape parasite infection in response to waterborne signals. Proc. R. Soc. Lond. B: Biol. Sci. 271, 733-738.

Touzet, N., Davidson, K., Pete, R., Flanagan, K., McCoy, G.R., Amzil, Z., Maher, M., Chapelle, A., Raine, R., 2010. Co-occurrence of the West European (Gr.III) and North American (Gr.I) ribotypes of Alexandrium tamarense (Dinophyceae) in Shetland, Scotland. Protist 161, 370-384.

Touzet, N., Franco, J.M., Raine, R., 2008a. Morphogenetic diversity and biotoxin composition of Alexandrium (Dinophyceae) in Irish coastal waters. Harmful Algae 7, 782-797.

Touzet, N., Franco, J.M., Raine, R., 2008b. PSP toxin analysis and discrimination of the naturally co-occurring Alexandrium tamarense and A. minutum (Dinophyceae) in Cork Harbour, Ireland. Aquat. Microb. Ecol. 51, 285-299.

Touzet, N., Keady, E., Raine, R., Maher, M., 2009. Evaluation of taxa-specific real-time PCR, whole-cell FISH and morphotaxonomy analyses for the detection and quantification of the toxic microalgae Alexandrium minutum (Dinophyceae), Global Clade ribotype. FEMS Microbiol. Ecol. 67, 329-341.

Townsend, D.W., Pettigrew, N.R., Thomas, A.C., 2005. On the nature of Alexandrium fundyense blooms in the Gulf of Maine. Deep-Sea Res. Pt. II 52, 2603-2630.

Turki, S., Balti, N., Ben Janet, H., 2007. First bloom of dinoflagellate Alexandrium catenella in Bizerte lagoon (northern Tunisia). Harmful Algae News 35, 7-9.

Turner, J.T., Tester, P.A., Hansen, P.J., 1998. Interactions between toxic marine phytoplankton and metazoan and protistan grazers. In: Anderson, D.M., Cembella, A.D., Hallegraeff, G.M. (Eds.), Physiological Ecology of Harmful Algae. Springer, Berlin, Heidelberg, New York, pp. 453-474.

Uchida, T., 2001. The role of cell contact in the life cycle of some dinoflagellate species. J. Plankton Res. 23, 889-891.

Usup, G., Pin, L.C., Ahmad, A., Teen, L.P., 2002. Alexandrium (Dinophyceae) species in Malaysian waters. Harmful Algae 1, 265-275.

Vila, M., Garcés, E., Maso, M., Camp, J., 2001. Is the distribution of the toxic dinoflagellate Alexandrium catenella expanding along the NW Mediterranean coast? Mar. Ecol. Prog. Ser. 222, 73-83. von Dassow, P., Montresor, M., 2011. Unveiling the mysteries of phytoplankton life cycles: patterns and opportunities behind complexity. J. Plankton Res. 33, 3-12.

Watras, C.J., Chisholm, S.W., Anderson, D.M., 1982. Regulation of growth in an estuarine clone of Gonyaulax tamarensis: salinity-dependent temperature responses. J. Exp. Mar. Biol. Ecol. 62, 25-37.

Wells, M.L., Mayer, L.M., Guillard, R.R.L., 1991. Evaluation of iron as a triggering factor for red tide blooms. Mar. Ecol. Prog. Ser. 69, 93-102.

Whedon, W.F., Kofoid, C.A., 1936. Dinoflagellata of the San Francisco region. I. On the skeletal morphology of two new species, Gonyaulax catanella and G. acatenella. Univ. Calif. Publs. Zool. 41, 25-34.

Wohlrab, S., Iversen, M.H., John, U., 2010. A molecular and co-evolutionary context for grazer induced toxin production in Alexandrium tamarense. PLoS One 5.

Yamaguchi, M., Itakura, S., Imai, I., Ishida, Y., 1995. A rapid and precise technique for enumeration of resting cysts of Alexandrium spp. (Dinophyceae) in natural sediments. Phycologia 34, 207-214.

Yamamoto, T., Tarutani, K., 1999. Growth and phosphate uptake kinetics of the toxic dinoflagellate Alexandrium tamarense from Hiroshima Bay in the Seto Inland Sea, Japan. Phycol. Res. 47, 27-32.

Yamasaki, Y., Katsuo, D., Nakayasu, S., Salati, C., Duan, J., Zou, Y., Matsuyama, Y. Yamaguchi, K., Oda, T., 2008. Purification and characterization of a novel high molecular weight exotoxin produced by red tide phytoplankton, Alexandrium tamarense. J. Biochem. Mol. Toxicol. 22, 405-415.

Yang, I., John, U., Beszteri, S., Gloeckner, G., Krock, B., Goesmann, A., Cembella, A., 2010. Comparative gene expression in toxic versus non-toxic strains of the marine dinoflagellate Alexandrium minutum. BMC Genomics 11, 248.

Yang, I., Selander, E., Pavia, H., John, U., 2011. Grazer-induced toxin formation in dinoflagellates: a transcriptomic model study. Eur. J. Phycol. 46 (1), 66-73.

Yoshimatsu, S., 1981. Sexual reproduction of Protogonyaulax catenella in culture. I. Heterothallism. Bull. Plankton Soc. Jpn. 28, 131-139.

Yoshimatsu, S., 1984. Sexual reproduction of Protogonyaulax catenella in culture. II. Determination of mating type. Bull. Plankton Soc. Jpn. 31, 107-111.

Yuki, K., Fukuyo, Y., 1992. Alexandrium satoanum sp. nov. (Dinophyceae) from Matoya Bay, central Japan. J. Phycol. 28, 395-399. 